FACULDADE DE ZOOTECNIA E ENGENHARIA DE ALIMENTOS

\title{
MARIA ANGÉLICA ROSA RIBEIRO
}

Efeitos deletérios de microcistina em matrinxã (Brycon cephalus) e tilápia nilótica (Oreochromis niloticus) 


\section{MARIA ANGÉLICA ROSA RIBEIRO}

\section{Efeitos deletérios de microcistina em matrinxã (Brycon cephalus) e tilápia nilótica (Oreochromis niloticus)}

Tese apresentada à Faculdade de Zootecnia e Engenharia de Alimentos da Universidade de São Paulo, como parte dos requisitos para a obtenção do Título de Doutor em Zootecnia.

Área de Concentração: Qualidade e Produtividade Animal

Orientadora: Profa. Dra. Elisabete Maria Macedo Viegas

Co-orientadora: Profa. Dra. Márcia Noélia Eler

Pirassununga

2010 
Dados Internacionais de Catalogação na Publicação

Serviço de Biblioteca e Informação da Faculdade de Zootecnia e Engenharia de Alimentos da Universidade de São Paulo

R484e Efeitos deletérios de microcistina em matrinxã (Brycon cephalus) e tilápia nilótica (Oreochromis niloticus) / Maria Angélica Rosa Ribeiro. --

Pirassununga, 2010.

$118 \mathrm{f}$.

Tese (Doutorado) - - Faculdade de Zootecnia e

Engenharia de Alimentos - Universidade de São Paulo. Departamento de Zootecnia.

Área de Concentração: Qualidade e Produtividade Animal.

Orientadora: Profa. Dra. Elisabete Maria Macedo viegas.

1. Piscicultura 2. Floração de algas 3. Cianobactéria 4. Toxicidade 5. Eutrófico 6. Histopatologia. I. Título. 
Agradeço a "Deus" pelo dom da vida

Posso todas as coisas em Cristo que me fortalece

Filipensis 4:13 
DEDICO À

"DEUS" pelo dom da minha vida

Aos meus Pais,

Argemiro Rosa e Anna Maria Luiza Machado Rosa, pelo

amor carinho e muita sabedoria na minha educação.

À minha família,

Meu esposo Donizetti Ap. Ribeiro (Piu) pelo amor que tem por mim e com meus filhos, Marcus Vinicius, Laila, Danilo, Manuele, que foram meu incentivo maior, e gratidão a "Deus" de tê-los em minha vida. 


\section{AGRADECIMENTOS}

A Deus pela sabedoria de cada dia

A minha professora orientadora Dra . Elisabete Maria Macedo Viegas pela orientação no curso de pós-graduação, pela amizade de longas datas, compreensão e sem dúvida um exemplo de profissionalismo. "A mestre com carinho".

Aos meus co-orientadores Dra Márcia Noélia Eler e Dr. Alessandro Minillo pela orientação sem dúvida pela nossa grande amizade mais do que amizade "amigos irmãos" que, nos anos de convivência, muito me ensinaram nos meus conhecimentos, contribuindo para meu crescimento cientifico e intelectual.

Ao Diretor da Faculdade de Zootecnia e Engenharia de Alimentos-Universidade de São Paulo-FZEA/USP/Pirassununga/SP, prof. Dr. Douglas Emygdio de Faria, pela oportunidade de realização do curso de doutorado.

Ao Presidente da Comissão de Pós-graduação da Faculdade de Zootecnia e Engenharia de Alimentos-Universidade de São Paulo-FZEA/USP/Pirassununga/SP, Prof. Dr. Paulo José do Amaral Sobral pela oportunidade do curso de doutorado.

As minhas irmãs, Marta, Marli, Márcia, Marisa e Rita um carinho especial a todas, com quem sempre pude contar em todas as horas difíceis, que "Deus com sua infinita bondade lhes abençoe sempre".

Ao Engenheiro Agrimensor e Técnico do Laboratório de química de água do CEPTA/ICMBio, Donizetti Aparecido Ribeiro, pela ajuda nas inúmeras análises Limnológicas e o apoio de todas as horas mesmo a mais difíceis, a quem amo de coração.

Ao Chefe Geral do Centro Nacional de Pesquisa e Conservação de Peixes Continentais/CEPTA/IBAMA e CEPTA/ICMBio e ao Ministério do Meio Ambiente/MMA, pela oportunidade de realização do doutorado. 
Aos motoristas do CEPTA/ICMBio, Alexandre Romero, Luiz Antonio Picolo, João Ferriolli, Noel Donizetti Martins, Jaime da Costa André, pela ajuda na hora das coletas, vocês são amigos maravilhosos, os sempre amigos e companheiros que Deus os abençoe pelo carinho e amizade.

Ao amigo e companheiro MSc. Nilton Pedro dos Santos da FZEA/USP/Pirassununga/SP, meus agradecimentos especiais pela ajuda na parte histológica, você nem imagina o quanto te quero bem.

Ao amigo e pesquisador Dr. Paulo Sergio Ceccarelli - CEPTA/ICMBio, em ceder o Laboratório de Ictiopatologia na realização dos bioensaios, sua ajuda foi valiosa, muito obrigada nossa amizade.

À Prof ${ }^{a}$ Dra $^{a}$ Aline Fernanda Campagna da UFSCar/São Carlos, pela ajuda na leitura das lâminas histológicas, meus primeiros ensinamentos da parte histológica, sua ajuda foi de grande valia, Deus lhe pague.

Ao Prof Dr. Francisco C. Blasquez da USP/São Paulo/SP, pela ajuda na leitura das laminas histológicas aprimorando meus conhecimentos, meu muito obrigado.

Ao Prof Dr. Ricardo Strefezzi, da FZEA/USP/Pirassununga/SP, pela ajuda na leitura das lâminas histológicas, sua ajuda foi valiosa, meu muito obrigado.

Ao amigo e pesquisador do CEPTA/ICMBio, Dr. José Sávio C. Melo pela ajuda na interpretação dos dados, os amigos são valiosos, pois você é um deles.

Aos amigos pesquisadores do CEPTA/ICMBio, Dra Roseli O. Ramos sempre amiga e incentivadora, Dr. Sérgio M. Ramos, sua ajuda foi valiosa, "Deus Ihes abençoe sempre pela nossa amizade".

Aos amigos Martinho Colpani Filho e a família Colpani, pela doação dos peixes, que "Deus com sua infinita bondade abençoe sempre essa família maravilhosa, esses amigos são pedras preciosas na vida da minha família". 
Aos Médicos Dr. Gefferson e Dra Angela, e aos amigos Ercília, Geraldo e Fabiana da FZEA/USP/Pirassununga/SP, pela compreensão e por tudo que fizeram pela minha família e principalmente pelo meu filho que "Deus Ihes abençoe sempre".

Ao Dentista, Dr. Élson e Manoel (Mané), FZEA/USP/Pirassununga/SP pelo carinho com que sempre nos atenderam.

As amigas da Pós-graduação, Conceição e Layla obrigada pela amizade sincera e pelo carinho, vocês são maravilhosas.

Aos da biblioteca da FZEA/USP, Marcelo (Corinthiano bom), Bernadete, Maria, Patrícia, Girley a todos o meu muito obrigado pela amizade sincera e pelo carinho, vocês são maravilhosos.

A bibliotecária do CEPTA/ICMBio Elenice B. Banin o meu muito obrigado pela correção das referências bibliográfica.

Aos amigos Francisco de Assis Neo, Sandoval dos Santos Junior, Janice Peixer, Leonardo Milano e Luis Alberto Gaspar pela amizade e companheirismo de todas as horas.

A amiga Mara A Pilon pela amizade de todas as horas, você é uma amiga especial.

As amigas Tchutchuca e Cristal pela proteção para com meus filhos.

A todos que de uma forma direta ou indiretamente contribuiram para que esta tese fosse concluída com sucesso, meu muito obrigado. 


\section{RESUMO}

O trabalho teve por objetivo avaliar a qualidade de água em viveiro de piscicultura com florescimento de cianobactérias e a toxicidade aguda ( $\left(L_{50}-24 h\right)$ de microcistina nas espécies matrinxã (Brycon cephalus) e tilápia nilótica (Oreochromis niloticus), bem como as alterações histológicas nas brânquias, rins e fígado nos peixes. Foi realizado o monitoramento da qualidade de água de um empreendimento piscícola localizado na cidade de Espírito Santo do Pinhal/SP, Brasil. Foram realizadas, em datas distintas, duas coletas de amostras de água contendo floração de microalgas, para análise da composição fitoplanctônica, determinação de toxinas e bioensaios toxicológicos em laboratório. Foram realizadas medições das variáveis físicas, químicas e biológicas da água, e determinação do estado trófico do viveiro monitorado. O viveiro apresentava-se hipereutrófico, com presença de cianotoxinas representadas por microcistinas com valores variando entre 229,2 e 147,4 $\mu \mathrm{g} / \mathrm{g}$. O florescimento de cianobactérias apresentou-se de composição mista, representado principalmente pelas espécies Anabaena circinalis, A. spiroides, Aphanocapsa sp., Microcystis aeruginosa, $M$. panniformis, $M$. viridis, $M$. cf. wesembergii, Pseudanabaena mucicola, entre outras espécies. Os resultados dos bioensaios com microcistina obtida do extrato bruto de fitoplâncton do florescimento não apresentaram letalidade para os peixes. Contudo, foram verificadas alterações em órgãos dos peixes testados, como a presença de depósitos hepatocelulares intracitoplasmáticos, degeneração vacuolar observada em epitélio tubular renal, e proliferação de epitélio de revestimento (hiperplasia) das brânquias, com casos de fusão total das lamelas secundárias, tanto para matrinxã como para tilápia nilótica. Extratos brutos de cianotoxina, em concentrações a partir de $125 \mathrm{mg} / \mathrm{kg}$ de peso corporal, injetados em peixes provocam efeitos deletérios com expressiva alteração nas brânquias, rins e fígado.

Palavras-chave: piscicultura, floração de algas, cianobactéria, toxicidade, eutrofico, histopatologia. 


\begin{abstract}
The aim of this study was to evaluate the water quality in fish earthpond with blooms of cyanobacterias and acute toxicity ( $\mathrm{DL}_{50}-24 \mathrm{hs}$ ) of microcystin in species (Brycon cephalus) and tilapia nilotica (Oreochromis niloticus) as well as histological changes in gills, kidney and liver in fish. Water quality monitoring was carryed out in a pisciculture in Espirito Santo do Pinhal city, SP, Brazil. There were two collections of water samples containing bloom of cyanobacteria for analysis of microalgae composition, toxin determination and toxicological bioassay in laboratory. Measurements of physical, chemical and biological variables were done and determination of trophic status of pond water were monitored. The results according to the trophic state index of samples taken showed hipereutrophic state for the pond water. Was evident the presence of cyanobacteria, represented by microcystins with values ranging from 229.2 to $147.4 \mu \mathrm{g} / \mathrm{g}$. The bloom of cyanobacteria presented mixed composition, represented mainly by species Anabaena circinalis, Anabaena spiroides, Aphanocapsa sp., Microcystis aeruginosa, Microcystis panniformis, Microcystis viridis, Microcystis cf. Wesembergii, Pseudanabaena mucicola among others. The results of tests with crude extract of bloom cyanobacteria did not show mortality of fish. However, there were changes in cellular structures of fish tested as the presence of hepatocellular intracytoplasmatic deposit, vacuolar degeneration observed in renal tubular epithelium, and proliferation of epithelial lining (hyperplasia) of gills, with cases of total fusion of secondary lamellae for both tilapias and for matrinxã. Crude extract of cyanotoxins, in concentrations of $125 \mathrm{mg} / \mathrm{kg}$ of body weight, injected in fishes provoke deleterious effect with expressive changes in the gills, kidney and liver.
\end{abstract}

Keywords: Pisciculture, algae bloom, cyanobactéria, mycrocistin, toxicity, eutrophic, histophatology. 


\section{LISTA DE FIGURAS}

Figura 1 - Localização dos compartimentos e municípios que compõem a bacia do rio Moji-Guaçu no trecho paulista (Fonte: RELATÓRIO ZERO/CETESB, 1999)

Figura 2 - Eluição gradiente em condições otimizadas para análise cromatográfica de microcistina-LR

Figura 3 - Perfil cromatográfico obtido por CLAE-DAD de amostra desprovida do padrão de microcistina-LR. 1) Metanol (T.R: 2.03). Coluna LC Column Zorbax ODS $\mathrm{C}_{18}(150 \mathrm{~mm} \times 4,6 \mathrm{~mm}$ ID, partículas de 5,0 $\mu \mathrm{m})$. Comprimento de onda de $237 \mathrm{~nm}$ 40

Figura 4 - Perfil cromatográfico obtido por CLAE-DAD do padrão de microcistina-LR e o perfil espectroscópico. 1) Metanol (T.R: 2.03) e 2) microcistina-LR (T.R: 8.61). Coluna LC Column Zorbax ODS $\mathrm{C}_{18}(150 \mathrm{~mm} \times$ 4,6 mm ID, partículas de 5,0 $\mu \mathrm{m})$. Comprimento de onda de $237 \mathrm{~nm}$

Figura 5 - Curva analítica da microcistina-LR no intervalo de concentração de 0,4 a $1,0 \mu \mathrm{g} / \mathrm{ml}$

Figura 6 - Câmara de sedimentação de contagem de fitoplancton modelo Sedgewick-Rafter S50 (microlitro)

Figuras 7 - Juvenis de matrinxã (Brycon cephalus) (a) e tilápia nilótica (Oreochromis niloticus) (b), utilizados nos bioensaios

Figura 8 - Concentrações de extratos algáceos (a) em solução fisiológica $(\mathrm{NaCl}-0,09 \%)$ nas doses: 0, 125, 250, 500, $1.000 \mathrm{mg} / \mathrm{kg}$, injetada intraperitonealmente nos peixes (b) 
Figura 9 - Ocorrência de florações de fitoplâncton (a, b) em viveiro de criação de peixes (Espírito Santo do Pinhal/SP). Fotos tiradas nos dias 27 de maio e 19 de agosto de 2007. Autor: Márcia Noélia Eler

Figura 10 - Espécies de algas encontradas nas amostras de água do viveiro das duas coletas: Pseudanabaena mucicola (a), Anabaena circinalis (b) e Microcystis aeruginosa (c). Todas são cianobactérias tóxicas de água doce (Falconer, 2004)

Figura 11 - Perfil cromatográfico e espectrofotométrico de microcistina-LR das amostras analisadas durante o estudo

Figura 12 - Análise histológica do tecido hepático de exemplares de matrinxã (Brycon cephalus) do controle (a), (b) com aspecto normal do epitélio hepático (HP) e da veia central (VC). Tratamento das doses de 125 (c), 250 (d), 500 (e) e 1.000 $\mathrm{mg} / \mathrm{kg}(\mathrm{f})$, a seta mostra a presença vacuolização do túbulo (VT), Ducto biliar (DB) moderadamente vacuolizado, Esteatose e (CONGESTÃO). Escala: (40-1300x1030S) (HE, $6 \mu \mathrm{m})$

Figura 13 - Análise histológica de tecidos renal de exemplares de juvenis de matrinxã (Brycon cephalus) do controle (a), (b) com aspecto normal dos Túbulos ( $T$ ) e Glomérulos normais $(G)$. Tratamento das doses de 125 (c), 250 (d), 500 (e) e 1.000 mg/kg (f), alterações caracterizadas pela vacuolização das células do epitélio (VT), com desorganização dos glomérulos e desintegração tubular seguida de nefrose. Degeneração Tubular (DT), Degeneração do Glomérulo (DG), Vacuolização do túbulo (VT). Escala: (40-1300x1030S) (HE, $6 \mu \mathrm{m})$.

Figura 14 - Índice de alteração histológica (IAH) dos órgãos fígado, rins e 
brânquias dos matrinxãs (Brycon cephalus) expostos à Microcystis aeruginosa ...................................................... 79

Figura 15 - Análise histológica do tecido branquial de exemplares de matrinxã (Brycon cephalus) do controle $(a, b)$ aspecto normal Seio Venoso Central (artéria que passa no filamento primário e leva o sangue para os filamentos das artérias secundarias). (SVC), Espaço Estratificado do filamento primário (EE), Lamela Secundária (LS), Espaço interlamelar (Ei). Tratamento das doses de 125 (c), 250 (d), 500 (e) e 1.000 mg/kg (f), Filamento Primário (FP), Hiperplasia (10 estágio) Confusão total $(H)$, Dilatação ( $1^{\circ}$ estágio) (D), Rompimento Lamelar ( $3^{\circ}$ estágio) (RL), Cartilagens ou Cartilaginoso (normais) (C), Deslocamento do Epitélio (DE), Fusão Total de todas as lamelas (Fusão Total é alteração de $2^{\circ}$ estágio) (FT), Congestão Sanguínea (entre o aneurisma e a dilatação, fase mais avançada que a dilatação) (CO), Célula Cloreto (proliferação alteração iônica desequilíbrio iônico aumento de células) (Hiperplasia aumento) (CC), Edema (mudança inflamatória presença de célula cloreto nas lamelas secundárias) (E). Escala: (40-1300×1030S) (HE, $6 \mu \mathrm{m})$

Figura 16 - Corte histológico do tecido hepático do matrinxã (Brycon cephalus) (a) e tilápia nilótica (Oreochromis niloticus) (b) controle injetados com $1 \mathrm{ml}$ de soro fisiológico. Observar o arranjo do ducto biliar (B), veia central $(V)$ e o pâncreas $(P)$. Notar seta $(\rightarrow)$ o formato dos hepatócitos e seus núcleos grandes e arredondados. (40-1300x1030S) (HE, 6 $\mu \mathrm{m})$

Figura 17 - Corte histológico do tecido hepático do matrinxã (Brycon cephalus) (a) e tilápia nilótica (Oreochromis niloticus) (b) - dose $125 \mathrm{mg} / \mathrm{kg}$. Notar a veia central (V), seja sínusóide hepático e a presença de pequena vacuolização. (40- 
Figura 18 - Corte histológico do tecido hepático do matrinxã (Brycon cephalus) (a) e tilápia nilótica (Oreochromis niloticus) (b) tratamento da dose $250 \mathrm{mg} / \mathrm{kg}$. Notar a veia central (V), e a presença de pequena vacuolização. (40-1300×1030S) (HE, $6 \mu \mathrm{m})$

Figura 19 - Corte histológico do tecido hepático de matrinxã (Brycon cephalus) (a) e tilápia nilótica (Oreochromis niloticus) (b) tratamento da dose $500 \mathrm{mg} / \mathrm{kg}$. Notar a veia central (V) e a

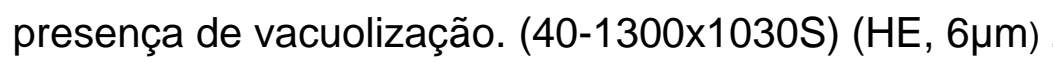

Figura 20 - Corte histológico do tecido hepático de matrinxã (Brycon cephalus) (a) e tilápia nilótica (Oreochromis niloticus.) (b) - dose $1.000 \mathrm{mg} / \mathrm{kg}$, notar a veia central $(\mathrm{V})$, seta $(\rightarrow)$ sinusóide hepático e o pâncreas (tecido pancreático - hepatopâncreas) $(P)$ presença de intensa vacuolização de glicogênio. (40-1300x1030S) (HE, $6 \mu \mathrm{m})$

Figura 21 - Corte histológico do tecido renal do controle de exemplares de matrinxã (Brycon cephalus) (a) e tilápia nilótica (Oreochromis niloticus) (b) submetidos a bioensaio injetados com $1 \mathrm{ml}$ de soro fisiológico. Notar que os glomérulos $(G)$ e Túbulo $(T)$

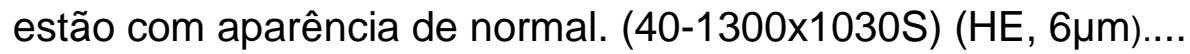

Figura 22 - Corte histológico do tecido renal de matrinxã (Brycon cephalus) (a) e tilápia nilótica (Oreochromis niloticus) (b) - tratamento da dose $125 \mathrm{mg} / \mathrm{kg}$. Notar a presença de túbulos (T) com pequena deformação. (40-1300x1030S) (HE, 6 $\mu \mathrm{m})$

Figura 23 - Corte histológico do tecido renal de matrinxã (Brycon cephalus) (a) e tilápia nilótica (Oreochromis niloticus) (b) - tratamento da 
dose $250 \mathrm{mg} / \mathrm{kg}$. Notar a presença de túbulos ( $\mathrm{T}$ ) e as setas $(\rightarrow)$ apresentando vacuolização nas células epiteliais. (40-

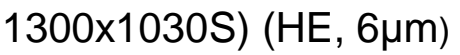

Figura 24 - Corte histológico do tecido renal de matrinxã (Brycon cephalus) (a) e tilápia nilótica (Oreochromis niloticus) (b) - tratamento da dose $500 \mathrm{mg} / \mathrm{kg}$. Notar a presença de túbulos $(T)$ e as setas $(\rightarrow)$ apresentando vacuolização das células epiteliais mais

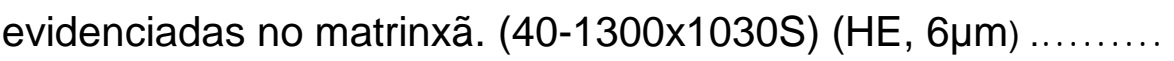

Figura 25 - Corte histológico do tecido renal de matrinxã (Brycon cephalus) (a) e tilápia nilótica (Oreochromis niloticus) (b) - tratamento da dose $1.000 \mathrm{mg} / \mathrm{kg}$. Notar a presença de túbulos (T) e as setas $(\rightarrow)$ apresentando vacuolização em células epiteliais (degeneração vacuolar) nas duas espécies. (40-1300×1030S) $(\mathrm{HE}, 6 \mu \mathrm{m})$

Figura 26 - Corte histológico do tecido branquial de matrinxã (Brycon cephalus) (a) e tilápia nilótica (Oreochromis niloticus) (b) - do controle injetados com $1 \mathrm{ml}$ de soro fisiológico. Observar os espaços interlamelares bem definidos ( $\mathrm{x}$ ) lamelas secundarias desenvolvidas (LS); filamento primário (F); seta células pilares

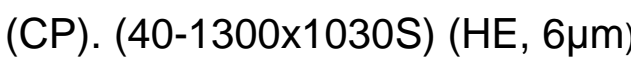

Figura 27 - Corte histológico do tecido branquial de matrinxã (Brycon cephalus) (a) e tilápia nilótica (Oreochromis niloticus) (b) tratamento da dose de $125 \mathrm{mg} / \mathrm{kg}$. Observar os espaços das lamelas secundarias as setas $(\rightarrow)$. Notar a desorganização das lamelas secundárias e a pequena congestão vascular. (401300x1030S) (HE, 6 $\mu \mathrm{m})$

Figura 28 - Corte histológico do tecido branquial de matrinxã (Brycon cephalus) (a) e tilápia nilótica (Oreochromis niloticus) (b) - 
tratamento da dose de $250 \mathrm{mg} / \mathrm{kg}$. Observar a cartilagem (C), proliferação epitelial (P). Notar na seta presença de proliferação epitelial das lamelas secundárias. (401300x1030S) (HE, 6 $\mu \mathrm{m})$

Figura 29 - Corte histológico do tecido branquial de matrinxã (Brycon cephalus) (a) e tilápia nilótica (Oreochromis niloticus) (b) tratamento da dose de $500 \mathrm{mg} / \mathrm{kg}$. Observar o a proliferação epitelial $(P)$ e a seta () fusão lamelar na matrinxã. Notar a presença de fusão total de lamelas (TF) na tilápia. (40-

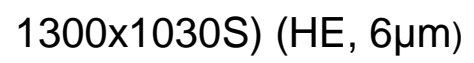

Figura 30 - Corte histológico do tecido branquial de matrinxã (Brycon cephalus) (a) e tilápia nilótica (Oreochromis niloticus) (b) tratamento da dose de $1.000 \mathrm{mg} / \mathrm{kg}$. Observar fusão total de lamelas (TF) nas setas $(\leftrightarrow)$. Notar a presença de fusão total de lamelas secundárias nas duas espécies. (40-1300×1030S) (HE, 6 $\mu \mathrm{m})$ 


\section{LISTA DE TABELAS}

Tabela 1 - Sumário da metodologia utilizada para a avaliação dos parâmetros físicos, químicos e biológicos das amostras de água

Tabela 2 - Eluição gradiente utilizada na análise cromatográfica de microcistina

Tabela 3 - Resultados de percentuais de recuperação e coeficientes de variação para o analito de microcistina-LR em amostras de água fortificadas nos três níveis propostos

Tabela 4 - Alterações histológicas consideradas na análise das brânquias de matrinxã e tilápia expostos a cepa de Microcystis aeruginosa e extratos algáceos Poleksic e Mitrovic-Tutundzic (1994) e Meletti (2003)

Tabela 5 - Alterações histológicas consideradas na análise dos rins de matrinxã e tilápia expostos a cepa de Microcystis aeruginosa e extratos algáceos. Baseados em Rigolin-Sá (1998) e Meletti (2003) 48

Tabela 6 - Alterações histológicas consideradas na análise do fígado de Matrinxã e tilápia expostos a cepa de Microcystis aeruginosa e extratos algáceos das coletas de campo. O estágio considerado para cada alteração está indicado na segunda coluna. Baseados em Rigolin-Sá (1998) e adotado por Meletti (2003)

Tabela 7 - Alterações histológicas consideradas na análise das brânquias, rins e fígados dos peixes 
Tabela 8 - Variáveis físicas, químicas e biológicas das coletas água do viveiro de criação (área de $20.000 \mathrm{~m}^{2}$ e profundidade de $1,8 \mathrm{~m}$ ) dos dias 27/05/2007 e 19/08/2007

Tabela 9 - Composição (divisão, gênero ou espécie) do fitoplâncton/bacterioplâncton identificados no viveiro das duas coletas de água

Tabela 10 - Presença de cianobactérias nas amostras de água do viveiro das duas coletas de água

Tabela 11 - Presença de microcistina detectadas na água das duas campanhas de coletas

Tabela 12 - Exemplares de matrinxã (Brycon cephalus) mortos durante 24 horas de bioensaio com Microcystis aeruginosa cultivada em laboratório

Tabela 13 - Alterações histológicas consideradas na análise do tecido hepático de matrinxã (Brycon cephalus) exposto a Microcystis aeruginosa. estágio considerado para cada alteração está indicado na segunda coluna. Baseado em Rigolin-Sá (1998), adotado por Meletti (2003) método ajustado e adaptado no presente trabalho

Tabela 14 - Alterações histológicas do tecido hepático dos matrinxãs (Brycon cephalus) expostos a Microcystis aeruginosa

Tabela 15 - Alterações histológicas consideradas nas análises de tecido renal de matrinxã (Brycon cephalus) exposto a Microcystis aeruginosa. O estágio considerado para cada alteração está indicado na segunda coluna 
Tabela 16 - Alterações histológicas do tecido renal dos matrinxãs (Brycon cephalus) expostos a Microcystis aeruginosa

Tabela 17 - Alterações histológicas na análise das brânquias de matrinxã (Brycon cephalus) expostos a Microcystis aeruginosa. O estágio considerado para cada alteração está indicado na segunda coluna ...

Tabela 18 - Alterações histológicas no tecido brânquial do matrinxã (Brycon cephalus) expostos a Microcystis aeruginosa

Tabela 19 - Alterações histológicas consideradas na análise do fígado de matrinxã e tilápia nilótica expostos às amostras de coleta de água. O estágio considerado para cada alteração está indicado na segunda coluna. Baseado em método de Rigolin-Sá (1998), adotado por Meletti (2003), ajustado e adaptado no presente trabalho

Tabela 20 - Alterações histológicas no tecido hepático do matrinxã e tilápia nilótica dos exemplares analisados

Tabela 21 - Alterações histológicas consideradas nas análises do tecido renal de matrinxã e tilápia nilótica expostos as amostra de coleta de água. O estágio considerado para cada alteração está indicado na segunda coluna

Tabela 22 - Alterações no tecido renal do matrinxã e tilápia nilótica das duas coletas de água

Tabela 23 - Alterações histológicas na análise das brânquias de matrinxã e tilápia nilótica exposto às amostras de coleta de água. O estágio considerado para cada alteração está indicado na segunda coluna ... 
Tabela 24 - Alterações histológicas do tecido branquial do matrinxã e tilápia nilótica das duas coletas de água................................................. 94 


\section{SUMÁRIO}

1. INTRODUÇÃ

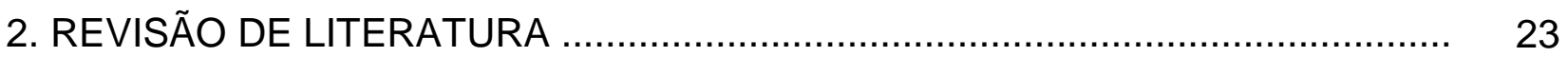

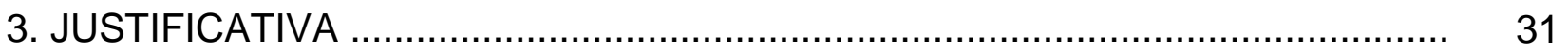

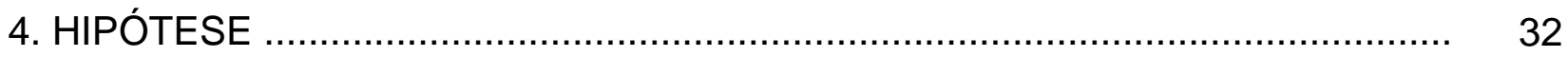

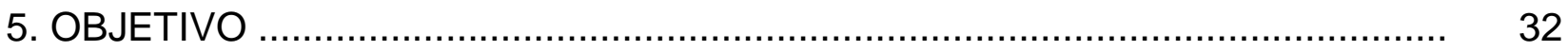

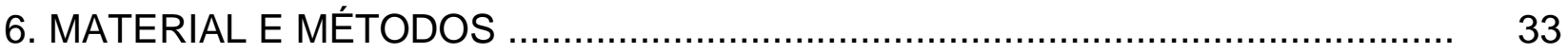

6.1 Caracterização da área da Bacia Hidrográfica do rio Moji-Guaçu .................... 33

6.2 Metodologia de análises físicas, químicas e biológicas da água ..................... 35

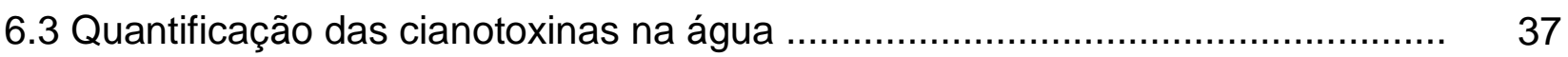

6.4 Extração de microcistina de amostras contendo florações de cianobactéria ..... 37

6.5 Quantificação da hepatotoxina microcistina ...................................... 37

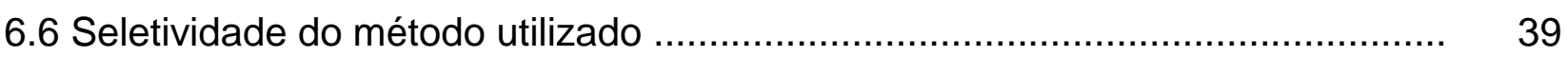

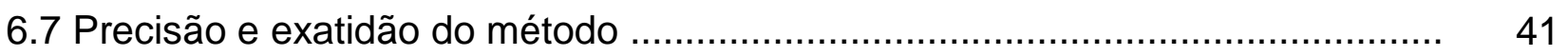

6.8 Análise Qualitativa e Quantitativa dos Grupos Fitoplanctônicos .................... 42

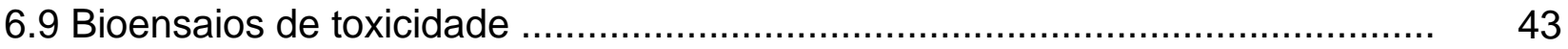

6.10 a) Cepa de Microcystis aeruginosa comprovadamente tóxica ....................... 44

6.10 b) Extratos liofilizados de cianobactérias coletadas em viveiro ...................... 45

6.11 Método de análise do material dos cortes histológico ............................... 46

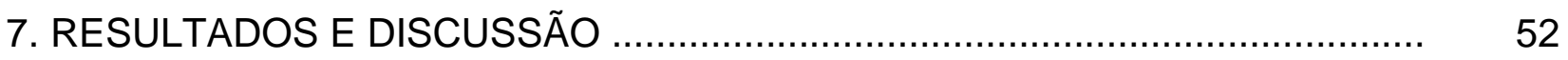

7.1 Parâmetros das análises físicas, químicas e biológicas das coletas de água.... 52

7.2 Avaliação da comunidade fitoplanctônica e presença de Cianobactéria........... 57

7.3 Microcistinas nas amostras das duas coletas de água .............................. 62

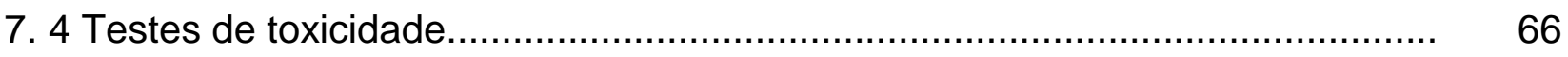


a) Teste ecotoxicológico com cepa de Microcystis aeruginosa ............................... 66

b) Teste ecotoxicológico com extratos de cianobactérias coletadas em viveiro: análise histológicas de fígado, rins e brânquias .

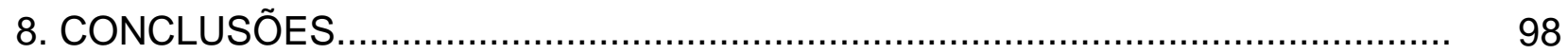

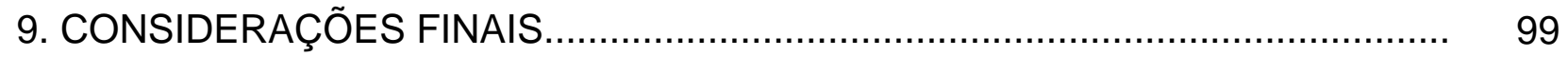

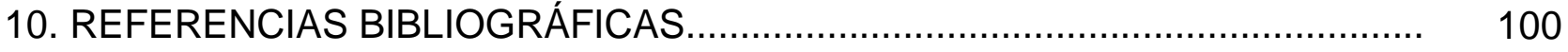

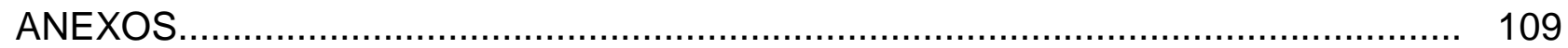




\section{INTRODUÇÃO}

A água é um recurso natural essencial, seja como componente bioquímico do seres vivos, como meio de vida de várias espécies vegetais e animais, como elemento representante de valores sociais e culturais e até como fator de produção de vários bens de consumo final e intermediário. Embora tenha sido sempre tratada pelo homem como um recurso natural inesgotável, hoje é séria a ameaça do fim deste recurso, em razão de seu crescente consumo com o aumento das atividades industriais e da população mundial. Um dos grandes desafios da humanidade neste século será, sem dúvida, o controle da qualidade da água para o abastecimento público (Minillo, 2005).

Cianofíceas ou cianobactérias são microorganismos com características celulares procariontes (bactérias sem membrana nuclear), porém com sistema fotossintetizante semelhante ao das algas (vegetais eucariontes). Inicialmente esses organismos foram classificados como algas unicelulares, mas estudos posteriores monstraram que possuem características de bactérias.

O florescimento de cianobactérias em sistemas de piscicultura tem sido pouco abordado no Brasil, principalmente em relação à toxicidade dessas algas em viveiros de peixes, embora os resultados de pesquisas atuais tenham demonstrado que o florescimento de algas, principalmente de cianobactérias, é expressivo, trazendo prejuízos ao produtor mediante a mortandade do pescado (Eler et al., 2006). Situações de riscos ambientais e de saúde já foram diagnosticadas em trabalhos de pesquisas, podendo ser identificada a mortandade de peixes em alguns estabelecimentos como em pesque-pague e viveiros de criação, principalmente em função da presença de espécies de algas pertencentes aos gêneros Microcystis, Anabaena, Aphanocapsa e Cylindrospermopsis (Eler et al., 2006, 2009).

Segundo Boyd e Queiroz (1997), os efluentes da piscicultura são frequentemente mais concentrados em sólidos, materiais orgânicos e nutrientes do que nas águas superficiais naturais onde são descarregados. Segundo esse mesmo autor, a intensificação da produção piscícola aumenta as concentrações de $\mathrm{CO}_{2}$, amônia, sólidos totais e matéria orgânica dissolvida na água.

Estudos sobre a qualidade da água têm sido desenvolvidos para avaliar os impactos da piscicultura ou de empreendimentos como os pesque-pague, permitindo 
identificar que o manejo adotado é, em sua maioria, inadequado para a sustentabilidade do sistema (Eler et al., 2006). Entre os vários fatores que contribuem para esta degradação, encontram-se a densidade de estocagem, o fluxo de água, o excesso e a qualidade da ração empregada (Eler et al., 2001). Conforme diagnósticos feitos, medidas preventivas não têm sido adotadas para evitar o acúmulo de material, a eutrofização, o aparecimento de algas cianofíceas, entre outros impactos; verificou-se que o efluente dos viveiros apresentavam concentrações elevadas de material em suspensão, nutrientes fosfatados, nitrogenados e comunidades biológicas diferentes, inserindo-se profundas modificações no corpo de água receptor (Eler et al., 2006).

Grande parte dos empreendimentos da piscicultura nacional estava, no final do século $X X$, concentrada nas regiões Sul e Sudeste, destacando-se os Estados de São Paulo, Paraná, Santa Catarina e Minas Gerais. Somente os Estados de São Paulo e Paraná contribuiam com mais de 60\% da atividade, sendo que o Estado de São Paulo contribuia com mais de $45 \%$ de toda a produção de peixes (Coelho, 1997). Dados recentes da produção aquícola nacional, apontam a contribuição da região Norte com 12,4\%, Nordeste, 29,9\%, Sudeste, 17,0\%, Sul, 30,6\% e CentroOeste, 19,1\%. Os Estados do Ceará, Rio Grande do Sul, São Paulo e Santa Catarina concentram produções acima de 20.000 t (IBAMA, 2007). Atualmente são mais de 300 pesque-pague espalhados pelo Estado São Paulo (Kitamura et. al., 1999). Em muitos pesques-pague, o florescimento de algas/cianobatérias vem se tornando um problema adicional, decorrente da falta de manejo adequado (arraçoamento, densidade de peixes e fluxo de água). Nesses casos a manutenção da qualidade da água é um fator importante para o desenvolvimento dos empreendimentos aquícola. 


\section{REVISÃO DA LITERATURA}

\section{Breve histórico das cianobactérias e a importância dessas para a ciência no estudo dos problemas ambientais}

A quase totalidade das espécies de seres vivos do planeta, incluindo os humanos, deve a sua existência às cianobactérias. Mesmo na era atual, as cianobactérias mantêm uma atuação indispensável para o bem estar dos ecossistemas. Entretanto, a civilização humana, em sua rápida expansão no último século, vem lançando uma grande quantidade de nutrientes no ambiente aquático, ocasionando a acelerada eutofização desses ecossistemas. Isso estimula a proliferação excessiva das cianobactérias, sob a forma de florescimentos, causando impactos negativos sobre à natureza e à civilização. Assim, o surgimento de um efeito duplo das cianobactérias - benéfico e deletério - é a confirmação de que "a diferença entre o remédio e o veneno está na dose" - preceito criado há 5 séculos por Paracelsus, precursor da ciência da toxicidade. As "doses" de eutrofização e a consequente floração de cianobactérias vêm aumentando rapidamente no mundo, causando problemas ambientais. A consequência direta das florações de cianobactérias tóxicas é o envenenamento de animais e do ser humano pela ingestão de água e potencialmente de pescado (da aquicultura), o que vem causando sérias implicações na saúde humana e na economia das atividades ligadas água (Azevedo et al., 2006; Tsukamoto e Takahashi, 2007; Santos e Bracarense, 2008).

\section{Cianobactérias}

As cianobactérias são organismos procariontes, fotossintéticos, encontrados em praticamente todo tipo de hábitat aquático. Ocorrem em águas com as mais diversas composições orgânicas e graus de salinidade (desde águas doces até hipersalinas). As cianobactérias são um componente normal do fitoplâncton e têm necessidades metabólicas muito simples. Como possuem clorofila a e pigmentos fotossintetizantes acessórios, esses organismos se desenvolvem muito rapidamente em condições de alta luminosidade, temperaturas elevadas da água $\left(15-30^{\circ} \mathrm{C}\right), \mathrm{pH}$ 
entre 6 e 9 e abundância de nutrientes, formando grandes massas superficiais de cor verde intensa denominadas florações (Azevedo et al., 2006; Santos e Bracarense, 2008; Sousa, 2009).

Deberdt et al. (2004) relata que cianobactérias pertencem a um antigo grupo de microorganismos, presente no planeta há três bilhões de anos, apresentando uma combinação de características encontradas tanto em algas como em bactérias. Em condições naturais, as cianobactérias vivem em equilíbrio como os demais grupos de algas. No entanto, em situações de enriquecimento nutricional, ou seja, eutrofização do corpo d'água e condições hidrológicas estáveis pode ocorrer o aumento da abundância de espécies de cianobactérias, dando origem a florações ou "blooms". Esses mesmos autores relatam que as florações causam impactos sociais, econômicos e ambientais, não apenas por sua biomassa contribuir para problemas estéticos como alterações na coloração da água (as "natas" verdes na superfície) e odor desagradável. A decomposição das florações de algas leva à desoxigenação, alterando a química da água e afetando a capacidade de sobrevivência de organismos aquáticos.

A cianobactéria acumula a toxina dentro de sua célula (toxina intracelular), como forma de defesa contra competidores e predadores, sem liberar a toxina enquanto está viva; apenas após a morte da cianobactéria, a toxina é liberada para o ambiente durante a lise da célula. As cianobactérias tóxicas mais frequentemente envolvidas em florações (Microcystis, Anabaena, Cylindrospermopsis e outras) se acumulam sobre a superfície da água, formando uma "nata" ou escuma verde flutuante (Tsukamoto e Takahashi, 2007).

Somente recentemente as toxinas responsáveis foram identificadas. Cerca de 40 gêneros de cianobactérias podem produzir cianotoxinas, mas as principais são: Microcystis, Anabaena, Aphanizomenon, Cylindrospermopsis, Lyngbya, Oscillatoria (Planktothrix) e Nostoc (Apeldoorn et al., 2007). As cianobactérias podem produzir hepatotoxinas (microscistina, nodularina e cilindrospermopsina), neurotoxinas (anatoxinas e saxitoxinas) e dermatotoxinas (lipopolissacarideos - LPS), que já causaram reações adversas e morte de animais e seres humanos (Azevedo et al., 2006). A maioria das hepatotoxinas intergra o grupo das microcistinas (MCs), uma família de toxinas produzidas por espécies de cianobactérias de água doce, principalmente por Microcystis aeruginosa (Carmichael, 1992, Cavalli et al., 2009), 
mas também por outras espécies deste gênero e outros gêneros como Anabaena, Oscillatoria (Planktothrix), Anabaenopsis e Nostoc.

\section{Cianotoxinas e sua ação no ambiente}

O fitoplancton é composto por uma imensa variedade de microalgas (diatomáceas, algas verdes, algas vermelhas, flagelados e outro grupos) e cianobactérias, uma intensa competição em curso d'água. Esta guerra de substâncias químicas é denominada alelopatia, efeito bioquímico inibidor tão amplo dentre esses seres, que chegam a ser altamente tóxico para animais, sendo por isso, denominadas toxinas (Tsukamoto e Takahashi, 2007).

As toxinas de cianobactérias são caracterizadas como endotoxinas por serem, geralmente, liberadas apenas quando acontece o rompimento da célula. Uma espécie de cianobactérias pode produzir mais de um tipo de toxina e dentro de uma mesma espécie podem existir cepas produtoras de toxinas. Estas moléculas estão divididas em três classes principais: dermatotoxinas (aplysiatoxina e lyngbyatoxinaa), neurotoxinas e hepatoxinas, sendo estas duas últimas as mais frequentemente encontradas em corpos d'água e que geram maiores preocupações (Carmichael, 1992; Soares, 2009).

\section{Hepatotoxinas}

As hepatotoxinas integram todas aquelas, substâncias que inibem 0 funcionamento das células do fígado, causando a morte das células deste órgão em decorrência da sua desestruturação celular. As toxinas pertencentes a esta classe são a microscistina (produzidas pelos gêneros Microcystis, Anabaena, Planktothrix e Oscillatória), a nodularina (produzida por Nodullaria) e a cilindrospermopsina (produzida por Cylindrospermopsis), (Azevedo et al., 2006; Tsukamoto e Takahashi, 2007).

Quando há ingestão de cianobactérias, estas toxinas são liberadas no estômago ou, preferencialmente, no íleo. Um vez absorvida, a microcistina rapidamente chega ao fígado pela circulação (portal) e por meio de receptores dos ácidos biliares, interage com os hepatócitos provocando alterações no citoesqueleto celular (Santos e Bracarense, 2008). 
O tipo mais comum de intoxicação envolvendo cianobactérias é causado por hepatotoxinas, que apresentam ação mais lenta, causando a morte entre poucas horas e poucos dias, em decorrência de hemorragia intra-hepática e choque hipovolêmico (aumento excessivo do fígado) (Azevedo et al., 2006).

A maioria das hepatotoxinas, incluindo a microcistina-LR, é hidrofílica, não atravessando as membranas celulares, sendo assim transportadas para o fígado por meio de transportadores iônicos multiespecíficos presentes nos canais biliares e no intestino delgado (Azevedo et al., 2006; Sousa, 2009). Estas toxinas exercem ação sobre a estrutura dos hepatócitos atrofiando-os, impedindo o contato entre eles e provocando hemorragias que fazem aumentar o peso do fígado e que poderão ser fatais (Azevedo et al., 2006). Este processo é irreversível e, mesmo não havendo letalidade, as lesões persistem verificando-se disfunção hepática. O grande fluxo de sangue ao fígado provoca falhas cardíacas, ocasionando daí a rápida letalidade (cerca de 20 minutos) após injecção intraperitoneal de Microcystis (Sousa, 2009). O atrofiamento do citoesqueleto dos hepatócitos dá-se devido à ação inibitória que as microcistinas e as nodularinas exercem nas fosfatases protéicas (enzimas reguladoras da síntese protéica), essenciais à sua manutenção (Soares, 2009). São estes mecanismos de interferência com as fosfatasses protéicas que tornam as hepatotoxinas promotoras de tumores (Sousa, 2009). Outro grupo é representado pelas Nodularinas normalmente produzidas por cianobactérias de ambientes marinhos como as do gênero Nodularia.

\section{Neurotoxinas}

As neurotoxinas representam substâncias que inibem o funcionamento das células nervosas, perturbando a movimentação e o equilíbrio dos peixes na água (Tsukamoto e Takahashi, 2007). Toxinas que atuam no sistema neuromuscular causando a paralisação dos músculos esqueléticos, respiratórios e causando morte por parada respiratória. Esses mesmos autores relatam que as neurotoxinas inibem a condução nervosa por bloqueio dos canais de sódio, afetando ou a permeabilidade ao potássio ou a resistência das membranas. Os sinais clínicos de intoxicação humana incluem tontura, adormecimento da boca e de extremidades, fraqueza muscular, náusea, vômito, sede e taquicardia. Os sintomas podem começar cinco minutos após a ingestão e a morte pode ocorrer entre duas a 12 horas. Em casos de 
intoxicação com dose não letal, geralmente os sintomas desaparecem de um a seis dias (Carmichael, 1992). Entretanto, não se tem conhecimento de efeitos crônicos por falta de estudos de longa duração com animais. Entre este grupo de neurotoxinas, destacam-se as saxitoxinas, anatoxina-s e a anatoxina(a)-s que podem ser produzidas por representantes dos gêneros Aphanizomenon, Oscilatoria, Anabaena, Cylindrospermopsis raciborskii, Planktothrix e Lyngbya.

\section{Dermatotoxinas}

A classe das dermatotoxinas constituem todas aquelas substâncias produzidas por cianobactérias filamentosas de água doce, salobra e marinha, pertencente aos gêneros Lyngbya e Schizothrix, que podem provocar dermatite severa, com irritação dos olhos e formação de bolhas e descamação da pele em pessoas expostas a elas no ambiente. O consumo de peixes e moluscos expostos à toxina pode causar diarréia e vômitos (Tsukamoto e Takahashi, 2007).

As legislações ambientais e sanitária brasileira e internacional estabelecem os limites máximos de cianobactérias em função do número de indivíduos ou células presentes num determinado volume de água. Assim, para cada filamento ou colônia gelatinosa devem ser contadas ao microscópio todas as células, para se obter o número ou volume total de suas células (biovolume). A legislação brasileira regula a densidade máxima admissível de cianobactérias no ambiente aquático, como por exemplo para a aquicultura a utilização da água doce classe dois, para os quais o limite máximo admissível de cianobactéria é de 50 mil células $/ \mathrm{ml}$ ou $5 \mathrm{~mm}^{3}$ (CONAMA 357/2005; Tsukamoto e Takahashi, 2007).

O uso dos testes de toxicidade permitem avaliar a ação de um determinado agente estressor e seus efeitos agudos e crônicos, sendo o primeiro aqueles que ocorrem rapidamente como um resultado da exposição ao agente tóxico por um curto período de tempo (para peixes, horas, dias ou semanas (Meletti, 2003; CETESB, 1990). O efeito agudo trata-se de uma resposta severa e rápida dos organismos a um estímulo, que se manifesta, em geral, num intervalo de 0 a 96 horas. Normalmente o efeito é a letalidade (ou para alguns organismos, como os microcrustáceos, pode ser a imobilidade. Para a avaliação do efeito agudo são consideradas a $\mathrm{CL}_{50}$ e a $C E_{50}$, sendo a primeira a concentração letal média, ou a concentração do agente tóxico que causa mortandade a 50\% dos organismos 
expostos num intervalo de 24 a 96 horas, e a última, a concentração efetiva média, ou a concentração do agente tóxico que causa imobilidade a $50 \%$ dos organismos expostos no mesmo intervalo de tempo. De acordo com Meletti (2003) o efeito crônico, pode ocorrer quando o agente tóxico produz efeitos deletérios como resultado de exposições repetidas ou exposições por longos períodos de tempo.

\section{Efeitos nocivos da presença de cianobactérias em peixes}

Embora ainda seja discutido o papel das toxinas produzidas pelas cianobactérias sobre os ambientes aquáticos, são claramente definidos os efeitos deletérios da presença destes organismos e seus metabólitos intracelulares sobre a biota aquática.

Glibert et al. (2002) relata problemas de mortandade de (Liza klunzingeri), acima de 2500 toneladas em uma enseada no Kuwait, os autores observaram que as condições ecológicas que levaram a mortandade de peixes, foi que a partir das condições ambientais alteradas ( $\mathrm{pH}$, nutrientes e condutividade) no ambiente aquático aumentaram a susceptibilidade dos peixes à doença. Os mesmos observaram ainda amostras adicionais de peixe para análise de identificação das espécies de algas na musculatura, onde foi encontrados nos animais estudados concentrações de toxinas abaixo dos limites esperados.

Estudos feitos por Carbis et al. (1997) revelaram que a ingestão $M$. aeruginosa com alto nível de microcistina provoca irritações do canal alimentar. Mudanças degenerativas no epitélio braquial da carpa estiveram associadas com prejuízo tóxico causado por microcistina. Estes autores inferem que baixa concentração de toxina presente no músculo pode, ainda, representar um risco significativo para a saúde humana, apesar desta cianotoxina não ter sido reconhecida como risco potencial à espécie testada.

Soares et al. (2004) verificaram a possibilidade de acumulação e depuração de microcistina (MCYSTs) em juvenis de Tilapia rendalli. E destacaram que esta espécie é capaz de acumular microcistina frente a disponibilidade de outras fontes de alimentação.

A exposição crônica de microcistina caracterizada pelo seu consumo oral por longo período pode representar um risco à saúde humana. No entanto, a ocorrência de algas tóxicas cianobactérias produzindo microcistina em tanques de aquicultura 
representam um risco à qualidade de peixe a ser consumido e, consequentemente, esta rota de exposição deve se tornar uma importante preocupação para as autoridades de saúde pública.

Molina et al. (2005) investigaram como as células de cianobactérias tóxicas liofilizadas afetam os parâmetros enzimáticos, tais como a fosfatase ácida (ACP), fosfatase alcalina (ALP) e alterações morfológicas em fígado, rim, brânquias e mucosa intestinal (somente histopatologia) da tilápia (Oreochromis sp.). Os peixes foram expostos a células de cianobactérias em suas dietas com dois intervalos de tempo diferentes (14 e 21 dias) e dois tipos de administração oral foram comparadas. Os autores concluíram que a forma como as microcistinas foram administradas não influenciou os parâmetros biológicos. Similarmente, a maioria das mudanças histológicas mais severas à maioria foi observada em dois organismos, embora as brânquias e intestinos também tenham sido afetados. A arquitetura do fígado ficou comprometida, e os hepatócitos com algumas alterações. Lesões do rim foram caracterizadas pela dilatação do espaço de Bowman e células epiteliais necróticas com tubulos de núcleos de pictnóticos alterados. Os autores concluíram que a exposição repetida a baixas doses de microcistina-LR das células de cianobactérias induzem toxidade na tilápia com efeitos adversos detectados.

Estudos realizados por Lützhøft et al. (1999) estabeleceram dados relacionados à toxicidade das algas à agentes antibacterianos, em três diferentes espécies de algas encontradas em viveiros de criação peixes: Microcystis aeruginosa como organismo modelo para cianobactéria em água doce; Rhodomonas salina como organismo modelo de algas em água salgada; e Selenastrum capricornutum, comumente usada no padrão teste de toxicidade das algas. Desta forma observaram que a $M$. aeruginosa é cerca de duas a três vezes mais sensível que a $R$. salina e $S$. capricornutum.

Lindholm et al. (1999) estudaram o lago Vargsundet em Åland, na porção sudoeste da Finlândia, o qual apresentou uma mortandade de peixe extensa, em Julho de 1997. Os autores apresentaram dados relativos à florescências persistentes de um agente neurotóxico, Prymnesium sp. e uma cianobactéria hepatotóxica, Planktothrix agardhii (Gomont), observando que os peixes $\mathrm{m}$ orreram na zona epilímnia, relativamente clara, onde foram registadas 10-40 milhões células de Prymnesium sp. por litro. Os peixes sobreviveram na zona metalimnia dominado pela espécie hepatotóxica $P$. agardhii. As camadas mais profundas eram 
anóxicas. As águas ricas em Primnesa permaneceram ictiotóxicas até o final de agosto, com baixas concentrações de clorofila podendo ser prejudiciais, sugerindo o monitoramento das águas.

Meletti (2003) estudou a degradação nas bacia do rio Piracicaba, Moji-Guaçu e Tibagi, baseado em testes de toxicidade de sedimentos in situ e em laboratório, com Serrapinnus notomelas e Danio rerio para utilização na avaliação dos efeitos dos efluentes e sedimentos. Nos cortes histológicos de peixes expostos às amostras de sedimento, observou que no tecido branquial, a alteração mais frequente foi à elevação epitelial, caracterizada pelo deslocamento da camada externa do epitélio da lamela secundária, que constitui uma das primeiras alterações observadas nas brânquias foram observadas outras alterações como, dilatação dos capilares das lamelas secundárias, congestão vascular, caracterizada pela estagnação do sangue, nas duas espécies. As alterações renais que ocorreram em maior frequência e intensidade nos peixes foram do tipo tumefação turva no rim, com células epiteliais tubulares inchadas ou hipertrofiadas. Alterações hepáticas como vacuolização citoplasmática nos hepatócitos podem ser uma medida indireta, porém não muito precisa, da quantidade de glicogênio ou de lipídeos nessas células.

Segundo Landsberg (2002) a ingestão de toxina depende do comportamento e do equilíbrio desta no meio ambiente, bem como a concentração de células na água. O desequilíbrio dessas cianobactéria no meio aquáticos causa uma concorrência entre elas tornando-as mais resistentes ao meio em que vivem, pela liberação de toxina na água, causando transtorno aos organismos aquáticos existente no meio.

Kamogae et al. (2002) verificaram o monitoramento de microcistinas em água para consumo humano na região de Itaipu, Paraná. Um total de 66 amostra coletada em local de captação (sem tratamento) e em três pontos do município (água tratada). As amostras sem tratamento apresentaram positividade em IC-ELISA de 92\%, comparadas a $75 \%$ do ponto um, $94 \%$ no dois e $100 \%$ no três. As condições climáticas com temperatura acima de $25^{\circ} \mathrm{C}$ influenciaram nos níveis de microcistina quando temperatura, luminosidade, nutriente e turbulência oferecem condições favoráveis a esta no meio ambiente. O desequilíbrio ecológico pode favorecer a prevalência de espécimes tóxica, assim como existe correlação positiva entre o aumento de microcistina com a elevação de temperatura, devido ao crescimento de cianobactérias. A ocorrência de maior concentração de microcistina (600 pg/ml) no 
ponto de captação coincidiu com o final da estiagem de seis dias, após temperatura favorável para o crescimento de cianofíceas. O desenvolvimento de cianofíceas toxigênicas provavelmente ocorreu devido à somatória de fatores ambientais (temperatura e pouca chuva).

\section{JUSTIFICATIVA}

Florescimento de algas em sistemas de piscicultura tem sido pouco estudado, principalmente em relação aos seus efeitos tóxicos diretos sobre os peixes e os seres humanos, tendo em vista a possibilidade de bioacumulação das toxinas sobre a musculatura do peixe, bem como sua possível transferência para o consumidor. Além disso, há uma perda econômica devido a grande mortandade de peixes que podem estar associadas aos eventos de floração. Entretanto, são poucos os estudos que abordam o impacto das florações de algas nas pisciculturas no Brasil, tanto do ponto de vista da qualidade e mortandade de peixes como da sua interferência na saúde do peixe. 


\section{HIPÓTESE}

As florações de cianobactérias nas pisciculturas incluem linhagens produtoras de cianotoxinas;

A exposição de peixes à cianotixinas promove comprometimento a tecido desses peixes.

\section{OBJETIVO}

\section{Objetivo Geral:}

Identificar toxinas em florescimento de cianobatérias e avaliar seus efeitos deletérios em peixes.

\section{Objetivos Específicos:}

1 - Identificar até o nível de espécie, as Cianobactérias presentes em viveiro de piscicultura;

2 - Identificar toxina de cianobactérias em amostras coletadas;

3 - Caracterizar a qualidade da água de viveiro de piscicultura com ocorrência de florescimento de cianobactérias.

4 - Determinar o efeito de cianotoxina em peixes matrinxã (Brycon cephalus) e tilápia nilótica (Oreochromis niloticus);

5 - Avaliar possíveis alterações histológicas de tecidos de peixes expostos a cianotoxina em bioensaios toxicológicos. 


\section{MATERIAL E MÉTODOS}

\section{1 - Caracterização da área da Bacia Hidrográfica do rio Moji-Guaçu}

A bacia hidrográfica do rio Moji-Guaçu está compreendida entre os paralelos 2145'e 2245', no Estado de São Paulo, com a região de nascentes localizada no Estado de Minas Gerais, no município de Bom Repouso e deságua no Rio Pardo, município de Pontal, São Paulo. Possui uma extensão de 473 Km, sendo 79,81\% de sua extensão em São Paulo e 20,19\% no estado de Minas Gerais. A bacia hidrográfica do referido rio possui $12.081,5 \mathrm{~km}^{2}$ de área de drenagem e abrange 48 cidades, sendo 10 cidades em MG e 38 cidades em SP (Figura 1), somando-se um contingente populacional de aproximadamente 1.360 .000 habitantes. Em consequência disso, o rio Moji-Guaçu tem recebido uma carga poluidora de aproximadamente 83,9 tonelada DBO/dia (RELATÓRIO ZERO, 1999).

Os principais afluentes do rio Moji-Guaçu pela margem direita são os rios Oriçanga, Itupeva, Cloro e Jaguari Mirim, e pela esquerda, Eleutério, do Peixe, do Roque, Quilombo e Mogi Mirim.

O solo da bacia hidrográfica é variado, sendo os principais tipos: Podzólico, solos podzolizados com cascalho, latossolo roxo, vermelho escuro, vermelho amarelo com fase arenosa, solos hidromórficos, aluviais, litossolo fase substrato granito, litossolo fase substrato arenito calcáreo e regossolos. O vale fluvial da bacia é constituído, basicamente, por leito basáltico, aflorado em derrames de corredeiras em Salto do Pinhal, Cachoeira de Cima em Mogi Mirim, Cachoeira de Baixo em MojiGuaçu, Cachoeira de Emas Pirassununga, Corredeira da Escaramuça em Santa Rita do Passa Quatro, e Corredeiras dos Três Cordões em Guariba. O desnível entre a foz e as nascentes é de $1.160 \mathrm{~m}$, as declividades variam de $14 \mathrm{~m} / \mathrm{km}$ ou $14 \%$ nos primeiros $10 \mathrm{~km}$ até $0,43 \mathrm{~m} / \mathrm{km}$, na parte baixa de seu curso.

O clima da região é compreendido por quatro divisões climáticas: clima mesotérmico, clima mesotérmico de inverno (inverno seco), clima tropical com estação chuvosa no verão e seca no inverno, clima mesotérmico úmido, sem estiagem (parte Norte, nas zonas mais elevadas, principalmente no Município de Amparo). As chuvas variam de 1.620 mm/ano, na região de Águas da Prata, até $1.330 \mathrm{~mm} / \mathrm{ano}$, nas vizinhanças de Jaboticabal. As máximas de chuva ocorrem nos 
meses de dezembro, janeiro e fevereiro, e as mínimas, nos meses de junho, julho e agosto. As médias anuais de temperatura variam de $20,5^{\circ} \mathrm{C}$ a $22,5^{\circ} \mathrm{C}$.

A bacia do Moji-Guaçu apresenta expressiva atividade agrícola desde a sua nascente até a sua foz com área de drenagem, sendo responsável por grande parcela da produção agropecuária do estado de São Paulo. Nesse âmbito se destacam as culturas da cana-de-açúcar, laranja, capim Brachiaria, eucalipto, algodão, soja, amendoim, morango, batata e tomate.

Além de todas as atividades antrópicas citadas, talvez a mais recente e em franco crescimento seja a indústria da piscicultura, que surge nesse quadro como atividade potencialmente impactante, contribuindo para a deterioração da qualidade das águas.

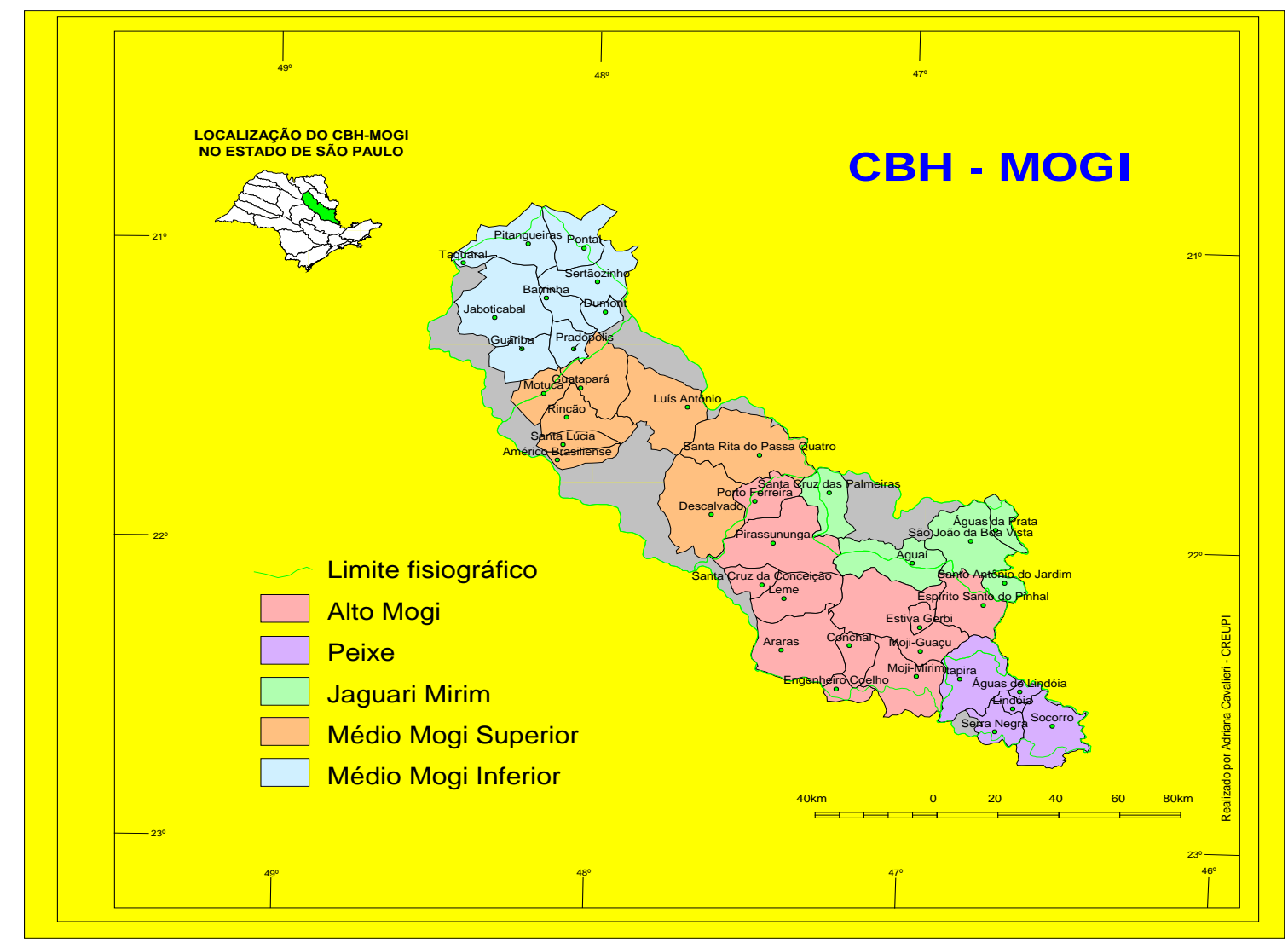

Figura 1- Localização dos compartimentos e municípios que compõem a bacia do rio Moji-Guaçu no trecho paulista (Fonte: RELATÓRIO ZERO/CETESB, 1999). 


\section{Deliamento do Estudo}

Este trabalho foi constituído de duas etapas (Etapas 1 e 2), sendo a primeira direcionada para avaliação de um empreendimento de piscicultura, incluindo entrevistas com proprietários e usuários, e a segunda envolvendo análises físicas, químicas e biológicas dos sistemas de cultivo.

Etapa 1 - Nesta etapa foi feito um inventário entre os proprietários (Formulário 1) e entre os clientes (Formulário 2) de pesques-pague. Foram visitados os principais pesques-pague da Bacia do Moji-Guaçu, sendo feita uma entrevista com cada proprietário e usuários, além das observações gerais efetuadas no local. O modelo de formulário utilizado para as entrevistas dos proprietários são apresentados nos Anexos 1 e 2 .

Etapa 2 - De posse das informações obtidas na Etapa 1 escolheu-se um empreendimento Santa Luzia em Espírito Santo do Pinhal/SP. Essa escolha foi feita em função do local já ter sido estudado (Eler et al., 2006, 2009). Para o trabalho atual, duas campanhas de coletas foram realizadas com a finalidade de verificar possíveis florações. Para tanto, foram realizadas duas coletas, sendo uma no início da estação seca (meados do outono) e outra no final do inverno. Foram tomadas amostras para análise das variáveis limnológicas.

\subsection{Metodologia de análises físicas, químicas e biológicas da água}

As metodologias utilizadas nas análises das variáveis físicas, químicas e biológicas são apresentadas na Tabela 1 e nos parágrafos seguintes. As amostras foram coletadas com o auxílio de uma garrafa de Van Dorn, em subsuperficie $(50 \mathrm{~cm}$ de profundidade) nos viveiros e na entrada e na saída da água do viveiro com balde graduado. 
Tabela 1 - Sumário da metodologia utilizada para a avaliação dos parâmetros físicos, químicos e biológicos das amostras de água.

\begin{tabular}{|c|c|c|}
\hline Variável & Método/equipamento & Autor \\
\hline Temperatura da água & Termistor/YSI 95 & \\
\hline Condutividade & Condutivímetro/ YSI 95 & \\
\hline Transparência & Disco de Secchi & \\
\hline Oxigênio dissolvido & Oxímetro/YSI 95 & \\
\hline $\mathrm{pH}$ & $\begin{array}{l}\text { Potenciométrico/Micro } \\
\text { nal (B474) }\end{array}$ & \\
\hline Alcalinidade & Titulométrico & BOYD (1981) \\
\hline Dureza & Titulométrico & BOYD (1981) \\
\hline Nitrito e Nitrato & Espectrofotômetro & MACKERETH et al. (1978) \\
\hline Amônia & Espectrofotômetro & KOROLEF (1976) \\
\hline Nitrogênio total & Espectrofotômetro & VALDERRAMA (1981) \\
\hline Fósforo total & Espectrofotômetro & VALDERRAMA (1981) \\
\hline $\begin{array}{l}\text { Fósforo dissolvido, fosfato } \\
\text { inorgânico }\end{array}$ & Espectrofotômetro & GOLTERMAN et al. (1978) \\
\hline $\begin{array}{l}\text { Material em suspensão } \\
\text { total }\end{array}$ & Gravimétrico & WETZEL e LIKENS (1991) \\
\hline $\begin{array}{l}\text { Material em suspensão } \\
\text { orgânico }\end{array}$ & Gravimétrico & WETZEL e LIKENS (1991) \\
\hline $\begin{array}{l}\text { Material em suspensão } \\
\text { Inorgânico }\end{array}$ & Gravimétrico & WETZEL e LIKENS (1991) \\
\hline Clorofila a & Espectrofotômetro & NUSCH (1980) \\
\hline
\end{tabular}

O Índice do Estado Trófico (IET) adotado foi o índice clássico introduzido por Carlson (1977), que utiliza-se de três variáveis: Transparência (m), Clorofila a $(\mu \mathrm{g} / \mathrm{L})$ e Fósforo Total ( $\mu \mathrm{g} / \mathrm{L})$. Também foi obtida a razão NT:PT conforme Overbeck (2000). 


\subsection{Quantificação das cianotoxinas na água}

As amostras de água foram coletadas com auxílio de uma garrafa de Van Dorn, sendo o material coletado mantido a baixa temperatura. As amostras de água tiveram o volume concentrado em aproximadamente 10 vezes. Amostras de florações foram coletadas utilizando balde graduado de polipropileno e rede de plâncton (20 $\mu \mathrm{m}$ abertura de malha) estas foram liofilizadas a $-30^{\circ} \mathrm{C}$ até plena desidratação. O material seco foi pesado em balança analítica, acondicionado a vácuo e mantido sob refrigeração para melhor preservação. Das amostras de água e do material das florações foram realizadas as análises de microcistinas, de acordo com os métodos propostos por Chu et al. (1990), Mahmood e Carmichael (1986), respectivamente. Todas as análises foram realizadas no laboratório de Saneamento da Faculdade de Engenharia de llha Solteira, UNESP, Campus de Ilha Solteira.

\subsection{Extração de microcistina de amostras contendo florações de cianobactéria}

Todo o material coletado em campo após ser liofilizado foi submetido à extração das microcistinas. Para tanto foram pesados $30 \mathrm{mg}$ de extrato algaceo sendo estes misturados em uma solução de metanol $75 \%$ por 18 horas, no escuro a $4^{\circ} \mathrm{C}$. Esta solução foi posteriormente centrifugada (3.500 rpm - $\left.10 \mathrm{~min}\right)$, e o sobrenadante recolhido e filtrado em membrana de fibra de vidro $(0,45 \mu \mathrm{m})$ para remoção de detritos celulares. Este material filtrado foi submetido a processo de concentração em fase sólida em coluna C-18 pré-ativados (10 ml de metanol 100\% seguido de $10 \mathrm{ml}$ de água Mili-Q). Após a passagem da amostra na coluna foi lavada a coluna com $4 \mathrm{ml}$ de metanol $20 \%$ e posteriormente seca a temperatura ambiente. A eluição da microcistina foi feita com $4 \mathrm{ml}$ de uma solução de acetonitrila com 0,05\% ( $v / v)$ ácido trifluoracético (TFA). O eluato foi recolhido, seco a $4^{\circ} \mathrm{C}$ e ressuspendido em $1 \mathrm{ml}$ de metanol 100\% e injetado em um cromatografo líquido de alta eficiência (CLAE - Shimadzu) para quantificação da microcistina.

\subsection{Quantificação da hepatotoxina microcistina}

Todo o material obtido nas etapas das coletas foi levado para o laboratório e submetido à análise de identificação e quantificação de microcistinas. Para esta etapa foi utilizado um cromatógrafo líquido de alta eficiência (Shimadzu, Japão), 
equipado com detector "Photodiode Array" (SPD-M20A), com duas bombas de alta pressão (LC-20AT e LC 20AD), em coluna de fase reversa C-18 (modelo Shim-pack) com 4,6 x $150 \mathrm{~mm}$ e diâmetro de partícula de $5 \mu \mathrm{m}$ segundo Meriluoto e Spoof (2005). Foram utilizados comprimentos de onda de $238 \mathrm{~nm}$ a $240 \mathrm{~nm}$ e empregando sotware LCsolution. A fase móvel foi constituída por dois componentes, uma com água Milli-Q e a outra por acetonitrila ambas acidificadas com 0,05\% (v/v) de ácido trifluoracético (TFA). Foi utilizado um fluxo de $1 \mathrm{ml} / \mathrm{min}$, com tempo de corrida cromatográfica de 12 minutos para cada amostra analisada $(25,0 \mu \mathrm{L})$, cada uma efetuada em triplicatas. Um padrão externo de calibração de (D-Leu $\left.{ }^{1}\right)$ - microcistinaLR, LR, RR e YR (99 \% de pureza) da Sigma-Aldrich foram utilizados.

Para as condições cromatográficas utilizadas nos ensaios foram considerados os fatores para os parâmetros cromatográficos de retenção $(k)$, de separação $\alpha$ e o número de pratos teóricos $(N)$. Por meio de uma eluição gradiente efetuou-se a análise cromatográfica para microcistina-LR (Tabela 2 e Figura 2) em matrizes sintéticas e em amostras reais. 
Tabela 2. Eluição gradiente utilizada na análise cromatográfica de microcistina.

\begin{tabular}{lcc}
\hline Tempo (min) & $\begin{array}{c}\text { Água (\%) } \\
(0,1 \% \text { TFA })\end{array}$ & $\begin{array}{c}\text { ACN (\%) } \\
(0,1 \% \text { TFA })\end{array}$ \\
\hline 0.01 & 70 & 30 \\
5.00 & 65 & 35 \\
15.00 & 20 & 80 \\
20.00 & 20 & 80 \\
22.00 & 65 & 35 \\
25.00 & 70 & 30 \\
30.00 & Finalização & \\
\hline \multicolumn{2}{l}{ TFA = Ácido trifluoracético e MeOH: Metanol. }
\end{tabular}

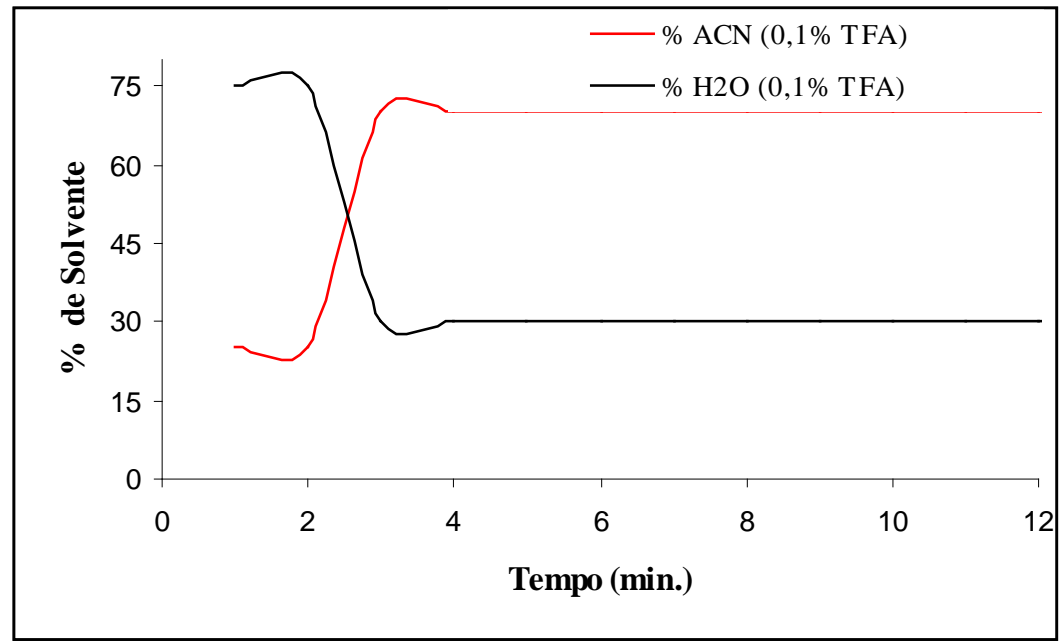

Figura 2. Eluição gradiente em condições otimizadas para análise cromatográfica de microcistina-LR.

\section{6 Seletividade do método utilizado}

A seletividade de um método instrumental de separação é a capacidade de avaliar, de forma inequívoca, as substâncias em exame na presença de componentes que podem interferir com sua determinação em uma amostra complexa (Cass e Degani, 2001). Isto assegura que o sinal não é influenciado por substâncias interferentes.

Para testar as seletividades dos métodos, foram comparadas matrizes isentas dos padrões de microcistina-LR (Figuras 3 e 4) ambos de alto grau de pureza, com matrizes contendo os padrões. Os perfis cromatográficos com os respectivos tempos de retenção para a microcistina-LR (T.R: 8.78) não apresentaram picos coeluidos 
após a análise dos seus espectros de absorbância demonstrando haver excelente seletividade.

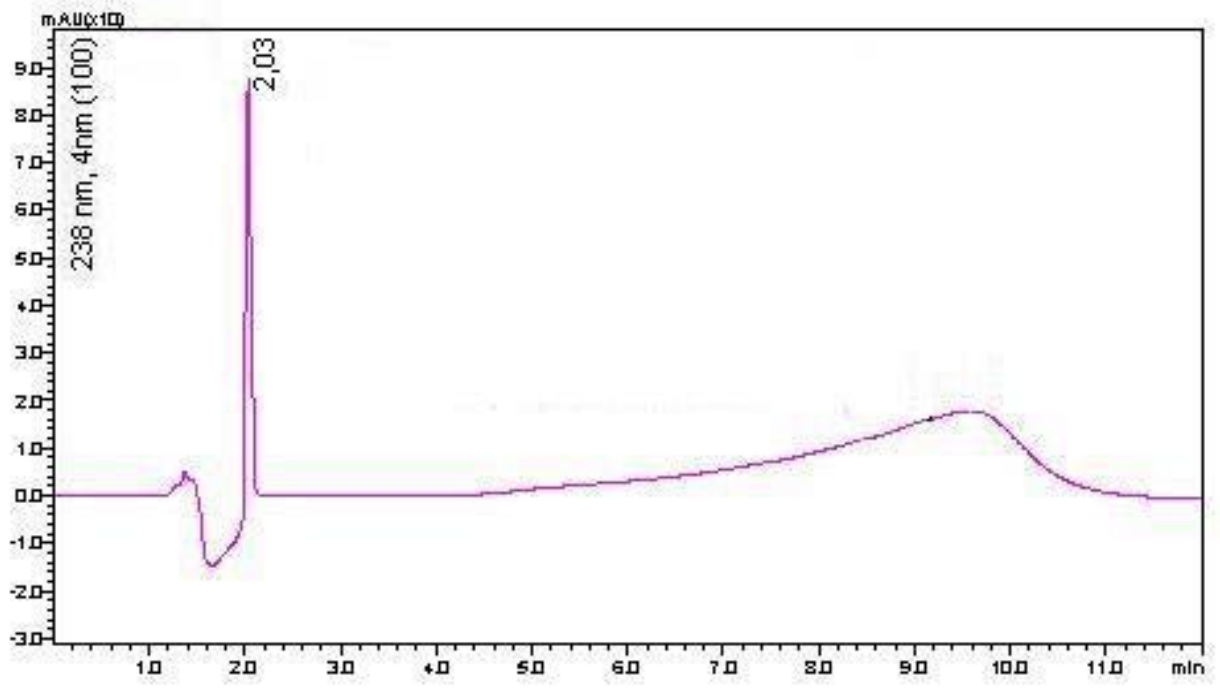

Figura 3. Perfil cromatográfico obtido por CLAE-DAD de amostra desprovida do padrão de microcistina-LR. 1) Metanol (T.R: 2.03). Coluna LC Column Zorbax ODS $\mathrm{C}_{18}(150 \mathrm{~mm} \times 4.6 \mathrm{~mm}$ ID, partículas de 5,0 $\mu \mathrm{m})$. Comprimento de onda de $237 \mathrm{~nm}$.

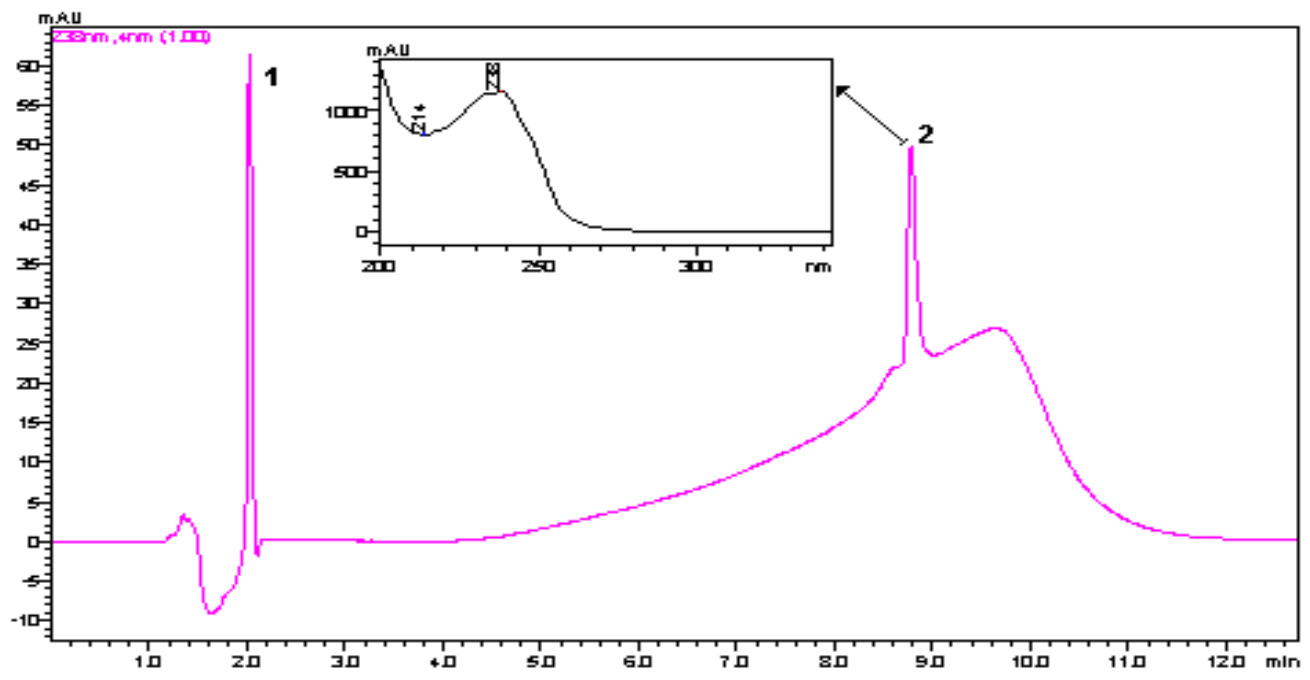

Figura 4. Perfil cromatográfico obtido por CLAE-DAD do padrão de microcistinaLR e o perfil espectroscópico. 1) Metanol (T.R: 2.03) e 2) microcistina-LR (T.R: 8.61). Coluna LC Column Zorbax ODS $\mathrm{C}_{18}(150 \mathrm{~mm} \times 4.6 \mathrm{~mm}$ ID, partículas de $5,0 \mu \mathrm{m})$. Comprimento de onda de $237 \mathrm{~nm}$. 


\section{7 Precisão e exatidão do método}

A precisão e exatidão do método utilizado foram determinadas a partir de ensaios de recuperação em amostras de águas fortificadas de uma curva analítica utilizada (Figura 5) com padrão de microcistina-LR em três níveis distintos de concentração (Tabela 3). A Tabela 3 apresenta as porcentagens de recuperação dos analitos (microcistina-LR) descritos nos três níveis estudados.

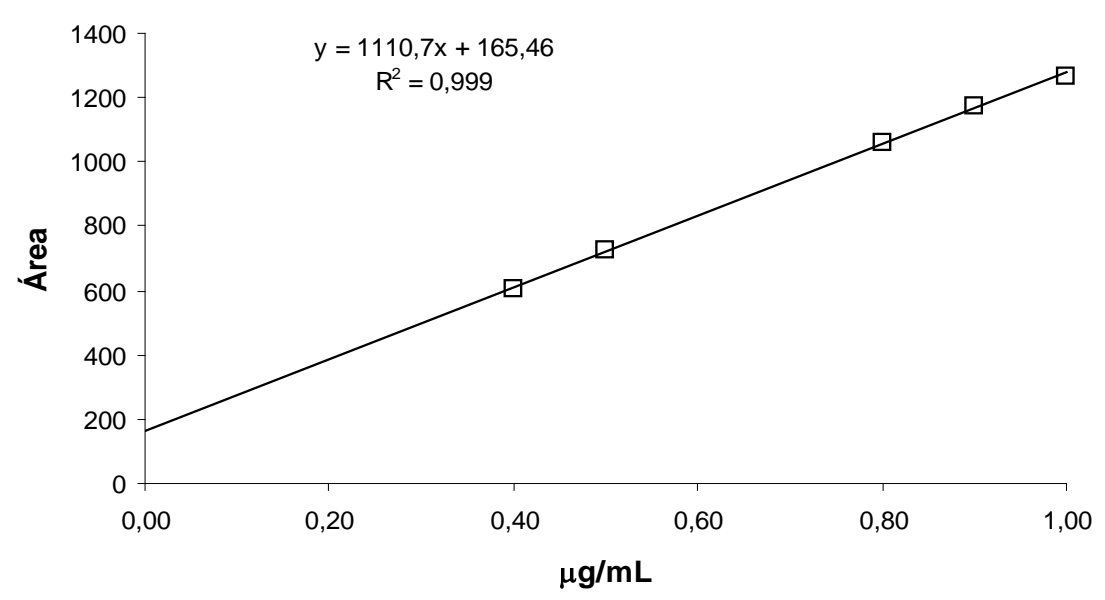

Figura 5. Curva analítica da microcistina-LR no intervalo de concentração de 0,4 a $1,0 \mu \mathrm{g} / \mathrm{ml}$

Tabela 3. Resultados de percentuais de recuperação e coeficientes de variação para o analito de microcistina-LR em amostras de água fortificadas nos três níveis propostos.

\begin{tabular}{lcccc}
\hline Analito & Nível de fortificação & $\begin{array}{c}\text { Recuperação * } \\
\mu \mathrm{CV} / \mathrm{ml}\end{array}$ & $\begin{array}{c}\mathrm{t}_{\text {calculado }} \\
(\%)\end{array}$ & $(\%)$ \\
\hline \multirow{2}{*}{ Microcistina-LR } & 0,87 & $113(97-102)$ & 1,7 & 2,33 \\
& 2,40 & $99(100-108)$ & 4,3 & $-1,27$ \\
& 4,40 & $101(99-105)$ & 2,1 & 1,84
\end{tabular}

Nota: * é a média aritmética ( $n=5)$ entre os valores de recuperação, CV: coeficiente de variação e $\mathrm{t} 95 \%=2,78$. 


\subsection{Análise Qualitativa e Quantitativa dos Grupos Fitoplanctônicos}

Essas amostras foram coletas na superfície com balde graduado e passado em rede de plâncton ( $20 \mu \mathrm{m}$ de abertura de malha) e preservadas em formol a $8 \%$ na proporção de 1:1 acondicionadas em frasco de 1 litro.

A identificação foi feita com base nas seguintes literaturas: Bicudo e Bicudo (1970); Hino e Tundisi (1977); Bourrelly (1981); Sant'anna et al. (1989); Eler (1996).

A contagem do fitoplâncton foi feita em câmara de SEDGEWICK-RAFTER. Foi utilizado o microscópio óptico invertido Leitz Periplan, modelo Diavert. Toda a análise quantitativa foi feita no Laboratório de Qualidade Química da Água do Centro Nacional de Pesquisa e Conservação de Peixes Continentais - CEPTA/ICMBio, Pirassununga, São Paulo. Para efeito de contagem, tomou-se a amostra e retirou-se uma subamostra de $1 \mathrm{ml}$, que foi diluída com água destilada em balão volumétrico, com capacidade de $10 \mathrm{ml}$. A amostra foi bem homogeneizada, retirando-se a seguir $1 \mathrm{ml}$, que foi colocado na câmara, onde permaneceu em repouso durante 30 minutos antes da contagem, esperando-se desta forma o processo de sedimentação.

A contagem foi feita em objetiva de $20 \mathrm{x}$, foram contados de 30 e 40 campos, de acordo com a concentração do plâncton na mesma (Figura 6). As contagens foram feitas no sentido horizontal, contando-se todos os campos em linha reta; até a obtenção do número pretendido de campos. A densidade de organismos foi obtida de acordo com a seguinte equação abaixo (equação 1).

$$
\text { № org. } / \mathrm{ml}=\frac{C \times 1.000 \mathrm{~mm}^{3}}{A \times D \times F}
$$

Onde:

$\mathrm{C}=$ número de organismos contados na amostra;

$A$ = área do campo;

$\mathrm{F}=$ número de campos contados;

$\mathrm{D}=$ profundidade do campo;

$1.000 \mathrm{~mm}^{2}$ = área total da câmara de Sedgewick-Rafter;

$1 \mathrm{~mm}$ = profundidade da câmara de Sedgewick-Rafter;

$1.000 \mathrm{~mm}^{3}=1 \mathrm{ml}$ = volume total da câmara de Sedgewick-Rafter. 


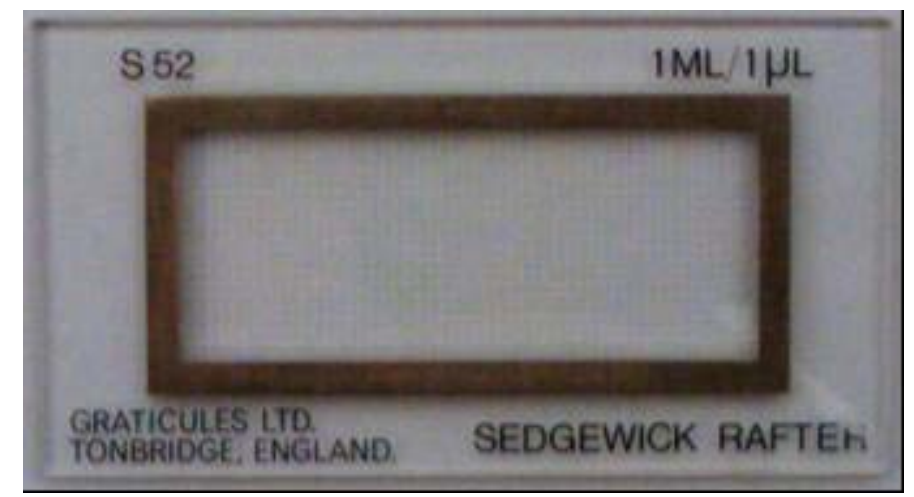

Figura 6. Câmara de sedimentação de contagem de fitoplancton modelo Sedgewick-Rafter S50 (microlitro).

Para análise da composição dos organismos fitoplanctônicos presentes nas amostras utilizou-se microscópio binocular equipado com câmera fotográfica. A identificação dos organismos foi realizada segundo características morfológicas e morfométricas, sendo essa análise efetuada ao menor nível taxonômico possível com base em bibliografia específica. A identificação das cianobactérias foi realizada em nível de gênero e espécie, segundo as características morfológicas e morfométricas descritas em literatura especializada e recorreu-se, quando necessário, ao auxilio de especialistas. Ao final, os táxons inventariados são apresentados em uma listagem, segundo critérios de classe, família, gênero e/ou espécie.

\subsection{Bioensaios de toxicidade}

Para avaliar os efeitos das toxinas das algas foram realizados bioensaios empregando-se juvenis de matrinxã (Brycon cephalus Günther, 1869) e tilápia nilótica (Oreochromis niloticus Linnaeus, 1757), espécies omnivoras com peso médio de 10 a 15 g, obtidas na piscicultura Águas Claras de Mococa, São Paulo (Figura 7). 
a

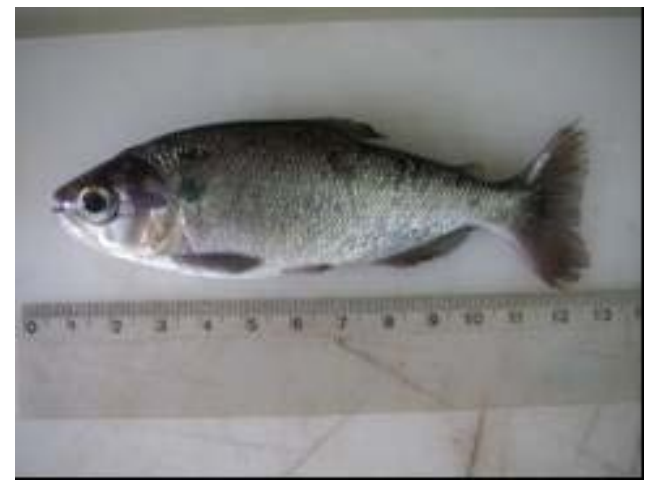

b

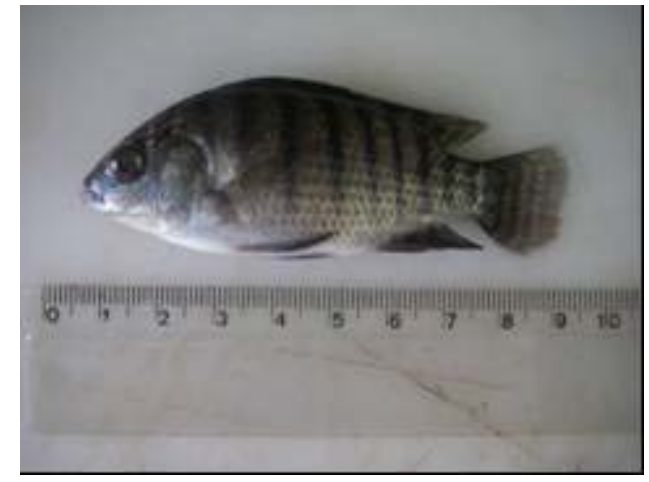

Figura 7. Juvenis de matrinxã (Brycon cephalus) (a) e tilápia nilótica (Oreochromis niloticus) (b), utilizados nos bioensaios.

Os peixes foram transferidos para caixas de fibra de vidro de cor preta de fluxo contínuo com capacidade de 60 L. A água de abastecimento provinha da represa de $50.000 \mathrm{~m}^{2}$ submetida à filtração, em filtro descendente constituído por areia de diferentes camadas e com granulométrias distintas. A temperatura da água seguia um padrão sazonal do ambiente em torno de $25-29^{\circ} \mathrm{C}$, sendo os peixes aclimatados durante 15 dias antes do experimento. Os animais foram alimentados com ração comercial com 40\% proteína bruta uma vez ao dia e 24 horas antes dos bioensaios toxicológicos a alimentação foi suspensa.

O bioensaio foi conduzido no laboratório de Ictiopatologia do Centro Nacional de Pesquisa e Conservação de Peixes Continentais - CEPTA/ICMBio, Pirassununga, São Paulo.

\subsection{0.a) Cepa de Microcystis aeruginosa comprovadamente tóxica}

Foi utilizada uma cepa de cianobactéria, a Microcystis spp. produtora da cianotoxina $\left(D-\right.$ Leu $\left.^{1}\right)$ - microcistina-LR. Esta cepa foi mantida em incubadora B.O.D no Laboratório de Saneamento do Departamento de Engenharia Civil da UNESP, Campus de Ilha Solteira.

A partir dessa cepa, a cultura foi produzida em escala massiva em caixas plásticas transparentes (10 L), em meio de cultivo específico (ASM-1), com temperatura $25 \pm 2^{\circ} \mathrm{C}$ e fotoperíodo (12 horas luz) controlados, com intensidade 
luminosa de $107 \mu \mathrm{E} / \mathrm{m}$, e com aeração constante. Ao final da fase de crescimento exponencial desta cultura (4 semanas), e com densidade da ordem de $10^{6} \mathrm{cel} / \mathrm{ml}$, estas foram recolhidas para a obtenção de extratos da cianotoxina microcistina. O inóculo, que deu origem a essa cultura, foi retirado de erlenmeyer mantido em incubadora em condições de assepsia adequada, temperatura $\left(20^{\circ} \mathrm{C}\right)$ e fotoperíodo (12 horas) controlados. Foram preparadas quatro concentrações crescentes (125, 250, 500 e $1.000 \mathrm{mg} / \mathrm{kg}$ ) dos extratos de algas liofilizados em solução fisiológica ( $\mathrm{NaCl}-0,09 \%)$. Para cada concentração foram utilizados cinco peixes (15 a $30 \mathrm{~g}$ ), sendo injetado, intraperitonealmente, $1 \mathrm{ml}$ para cada uma das doses, enquanto no controle foi injetada somente solução fisiológica (Figura $8 \mathrm{a}, \mathrm{b}$ ).

\subsection{0.b) Extratos liofilizados de cianobactérias coletadas em viveiro}

Foram realizadas coletas de florações de algas existentes na superfície do viveiro de água das duas coletas realizadas no empreendimento estudado, estas amostras foram passadas por rede de plâncton de 20 micrometro $(\mu \mathrm{m})$ e acondicionadas em galões de polipropileno com capacidade de 5 litros em seguida foram colocados em caixas de isopor com gelo e transportados até o laboratório de qualidade química de água - CEPTA, armazenados em freezer com temperatura de $-35^{\circ} \mathrm{C}$. Para a liofilização foi utilizado um equipamento de marca Labconco - serial $\mathrm{n}^{\circ}$ 098910 até a desidratação total das amostras com temperatura de $-30^{\circ} \mathrm{C}$. De posse do extrato algáceo liofilizado foram realizados os bioensaios e parte desse material foi para análise cromatográfica na UNESP/llha Solteira.

A toxicidade dos extratos liofilizados de cianobactérias foi determinada em bioensaios com matrinxã e tilápia por meio de injeções intraperitoneais. Para o teste de toxicidade aguda, utilizou-se o extrato algáceo liofilizado submetido a três ciclos de congelamento e descongelamento em solução fisiológica ( $\mathrm{NaCl}-0,09 \%)$ para o rompimento celular, sendo ao final centrifugado (4.000 rpm por 5 minutos). Foram preparadas quatro concentrações crescentes $(125,250,500$ e $1.000 \mathrm{mg} / \mathrm{kg})$ dos extratos de algas liofilizados em solução fisiológica ( $\mathrm{NaCl}$ - 0,09\%). Para cada concentração foram utilizados cinco peixes (10 a $15 \mathrm{~g}$ ), sendo injetado, intraperitonealmente, $1 \mathrm{ml}$ para cada uma das doses, enquanto no controle foi injetada somente solução fisiológica (Figura $8 \mathrm{a}, \mathrm{b}$ ). Os animais foram mantidos com alimentação constante e em observação contínua por duas horas e posteriormente a 
cada 30 minutos nas horas seguintes, sendo os principais sintomas de envenenamento registrados. Para os ensaios que obtiveram mortandades durante as 24 horas de monitoramento foram calculadas a $D_{50}-24$ hs utilizando o software Trimmed Spearman-Karber (Hamilton et al., 1977).

a

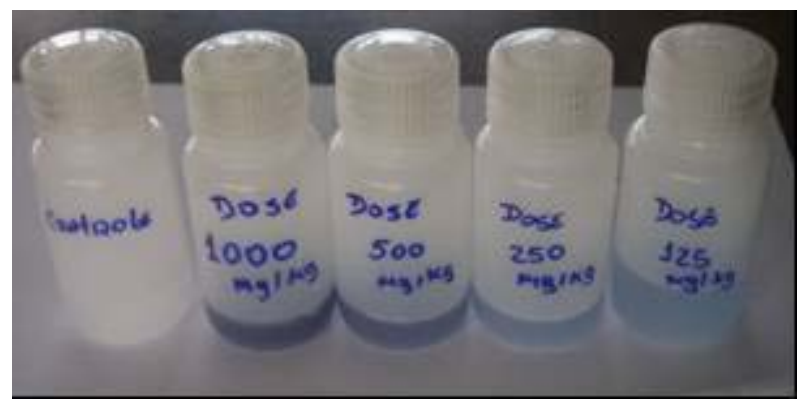

Figura 8- Concentrações de extratos algáceos (a) em solução fisiológica ( $\mathrm{NaCl}$ 0,09\%) nas doses: $0,125,250,500,1.000 \mathrm{mg} / \mathrm{kg}$, injetada intraperitonealmente nos peixes (b).

Para calcular as doses a serem testadas nos peixes do bioensaio foi utilizada a equação abaixo (equação 2).

\section{$\operatorname{DOSE}(\mathrm{mg} / \mathrm{kg})=$ Conc. Extrato $(\mathrm{mg} / \mathrm{ml}) \times 1.000(\mathrm{~g})$ Peso animal (g)}

Todos os animais após término dos ensaios foram eutanasiados por meio de desensibilização em água com gelo, incisão com ruptura da medula dorsal para a dissecação e a extração dos órgãos (fígado, rins e brânquias). Esses órgãos foram fixados em Bouin por 10 horas, troca sequencial com álcool 70\%, sendo o material emblocado em parafina para cortes histológicos com técnica de coloração por eosina hematoxilina (HE) no Laboratório de histologia da FZEA-USP/Pirassununga.

\subsection{Método de análise do material dos cortes histológico}

Para a análise das lâminas foram estabelecidos critérios para algumas alterações histopatológicas nas brânquias, rins e fígado, conforme mostram as 
Tabelas 4, 5 e 6 que foram classificadas em ordem de gravidade e tiveram a ocorrência anotada.

Tabela 4. Alterações histológicas consideradas na análise das brânquias de matrinxã e tilápia expostos a cepa de Microcystis aeruginosa e extratos algáceos Poleksic e Mitrovic-Tutundzic (1994) e Meletti (2003).

\section{ALTERAÇÕES HISTOLÓGICAS}

ESTÁGIO

\section{a) Hipertrofia e hiperplasia do tecido respiratório}

\begin{tabular}{|c|c|}
\hline$\Rightarrow$ Hipertrofia das células epiteliais & $\mathrm{I}$ \\
\hline$\Rightarrow$ Adelgamento epitelial & $\mathrm{I}$ \\
\hline$\Rightarrow$ Deslocamento ou elevação das células do epitélio & $\mathrm{I}$ \\
\hline$\Rightarrow$ Ruptura epitelial & II \\
\hline$\Rightarrow$ Hiperplasia das células epiteliais na base das lamelas secundárias & $\mathrm{I}$ \\
\hline$\Rightarrow$ Hiperplasia das células epiteliais ao longo das lamelas secundárias & $\mathrm{I}$ \\
\hline$\Rightarrow$ Fusão parcial (na base ou no topo) das lamelas secundárias & $\mathrm{I}$ \\
\hline$\Rightarrow$ Fusão completa de algumas lamelas secundárias & $\mathrm{I}$ \\
\hline$\Rightarrow$ Fusão completa de todas as lamelas secundárias & II \\
\hline$\Rightarrow$ Degeneração celular & II \\
\hline$\Rightarrow$ Infiltração de leucócitos no epitélio branquial & $\mathrm{I}$ \\
\hline
\end{tabular}

\section{b) Alterações nas células mucosas e cloreto}

\begin{tabular}{lc}
\hline$\Rightarrow$ Hipertrofia e/ou hiperplasia das células mucosas & I \\
\hline$\Rightarrow$ Presença de células mucosas nas lamelas secundárias & I \\
\hline$\Rightarrow$ Hipertrofia e/ou hiperplasia das células cloreto & I \\
\hline$\Rightarrow$ Presença de células cloreto nas lamelas secundárias & $\mathrm{I}$
\end{tabular}

c) Alterações nos vasos sanguíneos lamelares

\begin{tabular}{lc}
\hline$\Rightarrow$ Dilatação dos capilares & $\mathrm{I}$ \\
\hline$\Rightarrow$ Desarranjo dos capilares & $\mathrm{I}$ \\
\hline$\Rightarrow$ Congestão vascular & $\mathrm{I}$ \\
\hline$\Rightarrow$ Hemorragia causada por ruptura de capilares & $\mathrm{II}$ \\
\hline$\Rightarrow$ Aneurisma lamelar & $\mathrm{II}$ \\
\hline d) Estágio terminal & $\mathrm{III}$ \\
\hline$\Rightarrow$ Fibrose & $\mathrm{III}$ \\
\hline e) Parasitas branquiais & $\mathrm{I}$ \\
\hline
\end{tabular}


Tabela 5. Alterações histológicas consideradas na análise dos rins de matrinxã e tilápia expostos a cepa de Microcystis aeruginosa e extratos algáceos. Baseados em Rigolin-Sá (1998) e Meletti (2003).

\section{ALTERAÇÕES HISTOLÓGICAS}

ESTÁGIO

a) Alterações no tecido linfóide

\begin{tabular}{|c|c|}
\hline$\Rightarrow$ Perda do contorno celular ou contorno celular atípico & 1 \\
\hline b) Alterações nos glomérulos e túbulos renais & \\
\hline$\Rightarrow$ Degeneração hialina tubular leve & 1 \\
\hline$\Rightarrow$ Degeneração hialina tubular severa & II \\
\hline$\Rightarrow$ Hipertrofia das células tubulares & I \\
\hline$\Rightarrow$ Desorganização tubular & 1 \\
\hline$\Rightarrow$ Desorganização glomerular & 1 \\
\hline$\Rightarrow$ Degeneração tubular & II \\
\hline$\Rightarrow$ Degeneração glomerular & II \\
\hline$\Rightarrow$ Aumento do espaço da cápsula de Bowman & I \\
\hline$\Rightarrow$ Diminuição do espaço da cápsula de Bowman & $\overline{1}$ \\
\hline$\Rightarrow$ Dilatação dos capilares glomerulares & $\overline{1}$ \\
\hline$\Rightarrow$ Degeneração citoplasmática das células tubulares & II \\
\hline$\Rightarrow$ Degeneração nuclear das células tubulares & II \\
\hline$\Rightarrow$ Presença de túbulos em regeneração ou de "novos néfrons" & $\mathrm{I}$ \\
\hline$\Rightarrow$ Presença de muitos grânulos PAS-positivo no epitélio tubular & I \\
\hline$\Rightarrow$ Obstrução tubular & I \\
\hline$\Rightarrow$ Aumento do lúmen tubular & I \\
\hline$\Rightarrow$ Presença de tecido linfóide na cápsula de Bowman & II \\
\hline
\end{tabular}

c) Alterações nos vasos sanguíneos

\begin{tabular}{cc}
\hline$\Rightarrow$ Dilatação dos vasos sanguíneos & I \\
$\Rightarrow$ Hiperemia & II \\
\hline$\Rightarrow$ Ruptura dos vasos sangüineos & II
\end{tabular}

\section{d) Estágio terminal}


Tabela 6. Alterações histológicas consideradas na análise do fígado de matrinxã e tilápia expostos a cepa de Microcystis aeruginosa e extratos algáceos das coletas de campo. O estágio considerado para cada alteração está indicado na segunda coluna. Baseados em Rigolin-Sá (1998) e adotado por Meletti (2003).

\section{ALTERAÇÕES HISTOLÓGICAS}

ESTÁGIO

a) Alterações nos hepatócitos

\begin{tabular}{ll}
\hline$\Rightarrow$ Desarranjo dos cordões hepáticos & $\mathrm{I}$ \\
\hline$\Rightarrow$ Perda ou atipia do contorno celular & $\mathrm{I}$ \\
\hline$\Rightarrow$ Perda ou atipia do contorno nuclear & $\mathrm{I}$ \\
\hline$\Rightarrow$ Aumento do volume celular & $\mathrm{I}$ \\
\hline$\Rightarrow$ Aumento do volume nuclear & $\mathrm{I}$ \\
\hline$\Rightarrow$ Atrofia nuclear & $\mathrm{II}$ \\
\hline$\Rightarrow$ Intensa vacuolização citoplasmática & $\mathrm{I}$ \\
\hline$\Rightarrow$ Vacuolização nuclear & $\mathrm{II}$ \\
\hline$\Rightarrow$ Diminuição da frequência relativa de ocorrência de núcleos & $\mathrm{I}$ \\
\hline$\Rightarrow$ Degeneração citoplasmática & $\mathrm{II}$ \\
\hline$\Rightarrow$ Degeneração nuclear & $\mathrm{II}$ \\
\hline$\Rightarrow$ Rompimento celular & $\mathrm{II}$ \\
\hline$\Rightarrow$ Diminuição do glicogênio & $\mathrm{II}$ \\
\hline$\Rightarrow$ Estagnação biliar & $\mathrm{I}$
\end{tabular}

b) Alterações nos vasos sanguíneos

\begin{tabular}{lc}
\hline$\Rightarrow$ Aumento da frequência relativa de vaso sanguíneos & I \\
$\Rightarrow$ Hiperemia & II \\
$\Rightarrow$ Ruptura de vasos & II \\
\hline$\Rightarrow$ aumento do volume relativo dos vaso & $\mathrm{I}$
\end{tabular}

c) Alterações nos canalículos biliares

$\Rightarrow$ Degeneração dos canalículos biliares II

d) Estágio terminal

$\Rightarrow$ Necrose (focal ou total) III

Isso possibilitou a aplicação do Índice de Alterações Histológicas (IAH) adotado por Poleksic e Mitrovic-Tutundzic (1994), Takashima e Hibiya (1995) RigolinSá (1998) e Meletti (2003), para a avaliação dos efeitos das doses de microcistina nos tecidos dos peixes. Este índice permitiu uma classificação de lesões, em cada peixe, as quais foram consideradas neste trabalho, conforme a severidade, em estágios I, II e III. 
De acordo com os autores acima considerados, os estágios foram assim descritos:

Estágio I: Alterações leves em um grau que permite a recuperação da estrutura e função dos tecidos branquiais caso haja melhoria nas condições ambientais. "Sob condições ambientais inalteradas tais lesões devem persistir e, no caso de exposições a longo prazo, as alterações provavelmente vão progredir para o segundo estágio".

Estágio II: Alterações mais severas que comprometem a função dos tecidos; lesões reparáveis no caso de melhoria da qualidade da água, exceto quando grandes áreas nas brânquias forem danificadas; lesões que, em situação de poluição crônica ou então de aumento no nível de poluição, ou ainda de deterioração de outras condições ambientais (temperatura, pH, OD, etc), colocam em risco as funções branquiais, podendo levar a alteração do terceiro estágio.

Estágio III: Alterações em um grau que não permite a restauração da estrutura branquial. Mesmo com a melhoria da qualidade da água, ou com o fim da exposição aos agentes tóxicos, as alterações desse estágio levarão, mais cedo ou mais tarde, ao dano das funções branquiais vitais e até à morte.

A partir dessa classificação das lesões em estágios, os autores assumiram empiricamente que a cinética das alterações tem um crescimento exponencial. Então:

a) para o primeiro estágio: $10^{0}$

b) para o segundo estágio: $10^{1}$

c) para o terceiro estágio: $10^{2}$

Assim, os índices foram calculados de acordo com a seguinte equação abaixo (equação 3).

$$
\sum_{a_{i}+10}^{n a} \sum_{b_{i}+10^{2}}^{n b} \sum_{c_{i}}^{n c}
$$

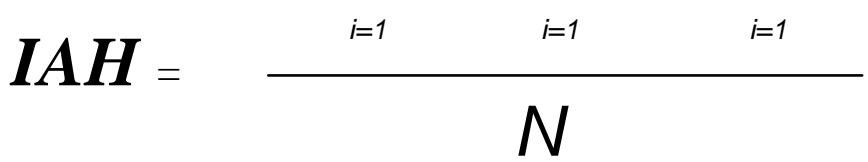


Sendo: a: primeiro estágio de alterações.

b: segundo estágio de alterações.

c: terceiro estágio de alterações.

na: número total de alterações consideradas como sendo do primeiro estágio.

nb: número total de alterações consideradas como sendo do segundo estágio

nc: número total de alterações consideradas como sendo do terceiro estágio.

$\mathrm{N}$ : Número de peixes analisados por tratamento.

No presente trabalho, esta equação foi utilizada para calcular o índice de alterações histológicas $(I A H)$ não só nas brânquias, mas também nos rins e fígado. Poleksic e Mitrovic-Tutundzic (1994) e Meletti (2003). Esses valores foram extrapoladas para cada alteração (Tabela 7).

Tabela 7. Alterações histológicas consideradas na análise das brânquias, rins e fígados dos peixes.

\begin{tabular}{ccl}
\hline Estagio & Valores de $\boldsymbol{I A H}$ & \multicolumn{1}{c}{ Efeitos } \\
\hline 0 & $0-10$ & órgão funcionalmente normal \\
I & $11-20$ & órgão com alterações de leves a moderadas \\
II & $21-50$ & órgão com alterações de moderadas a graves \\
III & $51-100$ & órgão com danos irreversíveis \\
\hline
\end{tabular}

Para a Tabela 4 são considerados os estágios para cada alteração histológica indicados na segunda coluna, baseado em Poleksic e Mitrovic-Tutundzic (1994) e Meletti (2003).

Nas Tabelas 5 e 6 são descritas alterações histológicas consideradas na análise matrinxã e tilápia nilótica. O estágio considerado, para cada alteração, está indicado na segunda coluna, com métodos baseados em Takashima e Hibiya (1995), Rigolin-Sá (1998), Meletti (2003) métodos ajustados e adaptados no presente trabalho. 


\section{RESULTADOS E DISCUSSÃO}

O pesque-pague estudado neste trabalho foi selecionado com base nos resultados obtidos a partir das analises dos formulários aplicados na Etapa 1, quando foram consideradas, entre outras, as informações referentes a densidade populacional elevada, baixo fluxo de água, variadas espécies de peixes, frequência de alimentação, tipo de alimento, forma de disponibilizar o alimento, cor e odor da água associada a floração de fitoplâncton e ocorrência de mortandade de peixes. Alem disso, esse empreendimento representava bem os demais pesques-pague da região e sua localização era de fácil acesso.

\subsection{Parâmetros das análises físicas, químicas e biológicas das coletas de água.}

Os resultados das análises físicas, químicas e biológicas da água dos viveiros de ciração estão descritas na Tabela 8. A temperatura da água apresentou seus valores acima de $20^{\circ} \mathrm{C}$ durante as duas coletas realizadas. $\mathrm{O} \mathrm{pH}$ apresentou padrões distintos entre seus valores, mas ambos próximos da neutralidade nas duas coletas; para condutividade da água os níveis foram ligeiramente elevados na primeira coleta, sendo que os níveis do oxigênio dissolvido apresentaram valores próximos da saturação. A transparência da água apresentou seus valores reduzidos para as duas coletas, enquanto a alcalinidade e dureza da água apresentaram valores característicos de águas ácidas. Os valores obtidos para os nutrientes nitrogenados atendendem aos padrões de qualidade de água estabelicidos pelo CONAMA (2005), pois o fator (nutriente) limitante não é o Nitrogênio. A Resolução CONAMA no 357/2005 esclarece, em seu Art. 10, § 3, que, para águas doces de classe 1 e 2 , quando o Nitrogênio for fator (nutriente) limitante para eutrofização, nas condições estabelecidas pelo órgão ambiental competente, o valor de Nitrogênio Total não deverá ultrapassar 1,27 mg/L para ambientes lênticos e 2,18 mg/L para ambientes lóticos, na vazão de referência.

Os valores de Fósforo Total não atendem aos padrões do CONAMA (2005), estando cinco vezes acima do valor máximo de $30 \mu \mathrm{g} / \mathrm{L}$ estabelecido na Resolução no 357/2005. Os valores da razão NT/PT indicam que o nutriente limitante é o fósforo (Overbeck, 2000). A água do viveiro amostrado apresentava-se hipereutrófica em ambas as coletas realizadas durante o estudo. Em estudos desenvolvidos no 
CAUNESP, Sipaúba-Tavares e Moreno (1994) encontraram altos teores de fósforo no período da seca (5mg/L), sendo que esses teores elvaram-se em função do aumento da densidade de estocagem de peixes. O estudo posterior de Lachi e Siapúba-Tavares (2008) corroborou com a conclusão de Sipaúba-Tavares e Moreno (1994). Isto é, as concentrações de PT no conjunto de viveiros do CAUNESP são intensificadas na seca (julho a outubro), consequentemente, ocorre o cresimento da biomassa fitoplanctônica, medida pela concentração de clorofila a.

Além disso, o fósforo é considerado a chave metabólica e o seu suprimento regula a produtividade das águas naturais Sipaúba-Tavares (1995) sendo um fator limitante nos viveiros de cultivo por ser um nutriente essencial na formação da estrutura celular do fitoplâncton. Em viveiros, a maior contribuição para a entrada de fósforo é via fertilização orgânica ou inorgânica, além de uma carga suplementar proveniente dos restos de alimentos oferecidos aos peixes.

Tabela 8. Variáveis físicas, químicas e biológicas das coletas água do viveiro de criação (área de $20.000 \mathrm{~m}^{2}$ e profundidade de $1,8 \mathrm{~m}$ ) dos dias 27/05/2007 e 19/08/2007.

\begin{tabular}{|c|c|c|}
\hline Variável & 27/05/2007 & $19 / 08 / 2007$ \\
\hline Temperatura da água $\left({ }^{\circ} \mathrm{C}\right)$ & 20,90 & 22,00 \\
\hline Oxigênio dissolvido (mg/L) & 9,60 & 8,80 \\
\hline Transparência (m) & 0,30 & 0,40 \\
\hline $\mathrm{pH}$ & 6,75 & 7,39 \\
\hline Condutividade $(\mu \mathrm{S} / \mathrm{cm})$ & 110,00 & 93,00 \\
\hline Alcalinidade (mg/L) & 32,00 & 48,00 \\
\hline Dureza (mg/L) & 28,00 & 30,00 \\
\hline Nitrito $\left(\mathrm{NO}_{2}-\right)(\mu \mathrm{g} / \mathrm{L})$ & 6,58 & 4,49 \\
\hline Nitrato $\left(\mathrm{NO}_{3}-\right)(\mu \mathrm{g} / \mathrm{L})$ & 592,81 & 624,36 \\
\hline Amônio $\left(\mathrm{NH}_{4-}^{-}\right)(\mu \mathrm{g} / \mathrm{L})$ & 821,28 & 988,59 \\
\hline Nitrogênio Total (NT) ( $\mu \mathrm{g} / \mathrm{L})$ & $1.384,42$ & $1.512,61$ \\
\hline Nitrogênio Orgânico Total (NOT) ( $\mu \mathrm{g} / \mathrm{L})$ & 7,00 & 8,00 \\
\hline Fósforo Total (PT) ( $\mu \mathrm{g} / \mathrm{L})$ & 114,24 & 107,68 \\
\hline Fosfato Total dissolvido (PD) ( $\mu \mathrm{g} / \mathrm{L})$ & 96,15 & 73,20 \\
\hline Fósforo Inorgânico(PI) ( $\mu \mathrm{g} / \mathrm{L})$ & 32,00 & 81,00 \\
\hline Material em suspensão total (mg/L) & 430,00 & 440,00 \\
\hline Material em suspensão orgânico (mg/L) & 230,00 & 240,00 \\
\hline Material em suspensão inorgânico (mg/L) & 210,00 & 220,00 \\
\hline Clorofila a ( $\mu \mathrm{g} / \mathrm{L})$ & $2.474,73$ & $1.444,89$ \\
\hline Razão NT:PT & 12,12 & 14,05 \\
\hline Índice de Estado Trófico (IET) & 86,00 & 82,00 \\
\hline
\end{tabular}


No viveiro estudado foi observado um evento de floração fitoplânctonica, que cobria metade do viveiro e se mantinha concentrado em direção ao monge pela ação do vento. O viveiro, destinado à criação intensiva de peixes para o abastecimento dos lagos de pesca, recebia continuamente ração de engorda, aplicação de medicamentos e suplementos de vitaminas, renovação de água com a finalidade de promover a saúde do animal. Apesar dos cuidados e prevenção para a manutenção da qualidade de água, verificou-se que a coloração da água era verde-escura, com presença de espumas superficiais, sendo que em alguns locais essa coloração era mais acentuada (Figura 9 a, b). Segundo informações do proprietário, o evento de floração já perdurava por aproximadamente 30 dias.

a

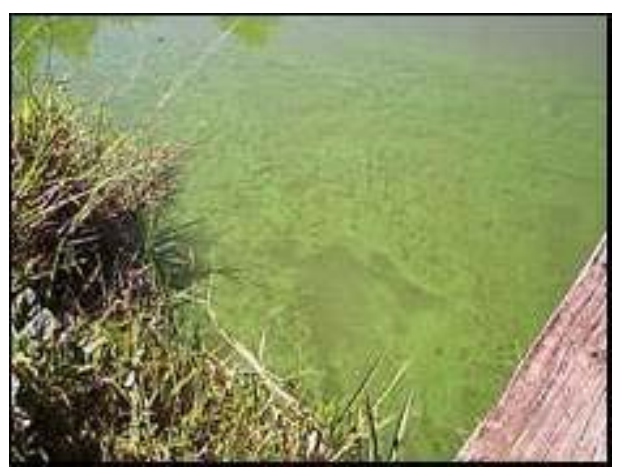

b

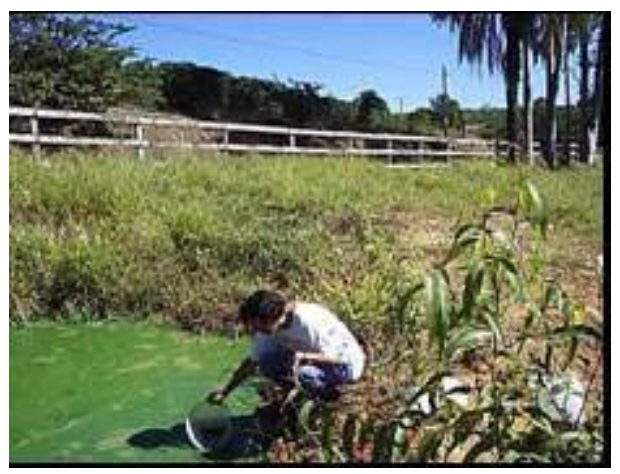

Figura 9 - Ocorrência de florações de fitoplâncton $(a, b)$ em viveiro de criação de peixes (Espírito Santo do Pinhal/SP). Fotos tiradas nos dias 27 de maio e 19 de agosto de 2007. Autor: Márcia Noélia Eler.

De acordo com a avaliação da percepção de qualidade ambiental verificaramse os seguintes aspectos: a) odor semelhante ao de Hexacloreto de Benzeno (BHC); b) urticária nas mãos ao tocarem a floração. A amostra retirada e transportada para o laboratório apresentou as mesmas características ao serem processadas dias depois, isto é, intenso odor de BHC e tendência à urticária durante a manipulação.

Segundo declaração do proprietário da fazenda, não ocorreu mortandade de peixes no local. Entretanto, os peixes apresentavam movimento natatório errático e em parafuso na superfície da água, o qual corresponde a sinal clínico de intoxicação. Além disso, nadavam com a boca aberta próximo à superfície pela manhã, comportamento em resposta à depleção das concentrações de oxigênio dissolvido no período noturno. O aporte de nutrientes, via ração, é muito elevado nos viveiros 
de criação, observando que o proprietário alimentava os peixes duas vezes ao dia, no primeiro horário da manhã e no final da tarde, sendo que o viveiro recebia em média, por dia, $120 \mathrm{~kg}$ de ração. Porém, grande parcela dessa carga orgânica é perdida para o sedimento, sendo disponibilizada para ciclagem dos nutrientes e, posteriormente, aproveitada na produção primária do fitoplâncton.

De acordo com Paerl e Tucker (1995), a disponibilidade de nitrogênio e fósforo influencia diretamente a estrutura da comunidade fitoplanctônica, principalmente no crescimento e na acumulação de biomassa na coluna d'água. Segundo esses autores, a baixa razão NT:PT é o fator determinante na dominância de cianobactérias; concluiram que quando a razão NT:PT igual a 29 demonstra ausência ou raridade de cianobactérias na coluna d'água. Essa hipótese pode ser consistente e tomada como um indicador auxiliar durante um evento de monitoramento da qualidade ambiental de um empreendimento piscícola.

Neste trabalho foram encontradas razões NT:PT de 12,12 (27/05/2007) e 14,06 (19/08/2007) compatíveis com o florescimento de fitoplâncton, com a presença de espécies de cianobactérias dominantes na comunidade analisada. Estes resultados são semelhantes aos obtidos por Eler et. al. (2006), que encontraram a razão NT:PT igual a 16 no mesmo viveiro de criação de peixes estudado neste trabalho. Salienta-se que o florescimento de cianobactérias estava presente em ambas as coletas.

De acordo com a literatura, existe uma capacidade em alguns gêneros para fixar o nitrogênio atmosférico $\left(\mathrm{N}_{2}\right)$, o que certamente permitiria às cianobactérias formarem florações e crescerem em concentrações baixas desse nutriente. Para Tucker e Plöeg (1993), a razão NT:PT no verão variou entre 4 e 16 em viveiros de bagre-de-canal (Ictalulus punctatus) no Mississipi. Os autores reforçam que esses viveiros estavam dominados por cianobactérias.

Segundo Bittencourt-Oliveira et al. (2001), ambientes com temperaturas diárias em torno de $25^{\circ} \mathrm{C}$, pH 7,5 e razões NT:PT entre 20:1 e 10:1 propiciam o crescimento de algumas populações de cianobactérias, sendo que estas conferem sabor e odor desagradáveis à água, bem como o desequilíbrio ecológico do ecossistema aquático.

O Índice de Estado Trófico (IET) ficou acima de 82 (Tabela 8), indicando que o viveiro apresentava-se hipereutrófico. Resultados semelhantes foram encontrados por Eler et al. (2006; 2009). O Índice de Estado Trófico (IET) tem por finalidade 
classificar corpos d'água em diferentes graus de trofia, ou seja, avalia a qualidade da água quanto ao enriquecimento por nutrientes e seu efeito relacionado ao crescimento excessivo das fitoplâncton.

Os resultados das análises de clorofila a encontrados ficaram acima de 48 vezes o valor máximo de $30 \mu \mathrm{g} / \mathrm{L}$, estabelecido pelo CONAMA (2005), para água doce de Classe 2 (Tabela 8). 


\section{2 Avaliação da comunidade fitoplanctônica e presença de Cianobacteria}

A composição fitoplanctônica em ambas as datas de coletas foram semelhantes, com diferenças na densidade de células encontras. A Tabela 9 apresenta os táxons que foram identificados nas amostras.

A comunidade fitoplanctônica, considerando todo o período amostrado e todos os pontos, apresentou 41 táxons, sendo estes distribuídos da seguinte forma: a classe Bacillariophyceae contribuiu com 6 táxons (5\%); a Chlorophyceae, com 14 (37\%); a Cyanobacteria, com 18 (43\%); a Dinophyceae (Dinoflagelado) com 1 (1,9\%); a Chrysophyceae, com 1 (1,9\%).

Salienta-se que na amostra analisada e referente ao outono predominavam na comunidade fitoplanctônica as espécies Pseudanabaena mucicola e Microcystis aeruginosa, já no inverno o plâncton era dominado pela espécie Anabaena circinalis na segunda coleta, sendo que $P$. mucicola foi encontrada associada à mucilagem de M. aeruginosa (Figura $10 \mathrm{a}, \mathrm{b}, \mathrm{c}$ ). Os filamentos encontravam-se espalhados pela mucilagem das vesículas gasosas no centro, assim como sob a mucilagem da periferia da colônia. Encontrou-se uma variação de três a seis células por filamento de P. mucicola. De acordo com Eler et al. (2006) as consequências fisiológicas resultantes dessas associações ainda continuam desconhecidas e dependentes de mais pesquisas. 
a

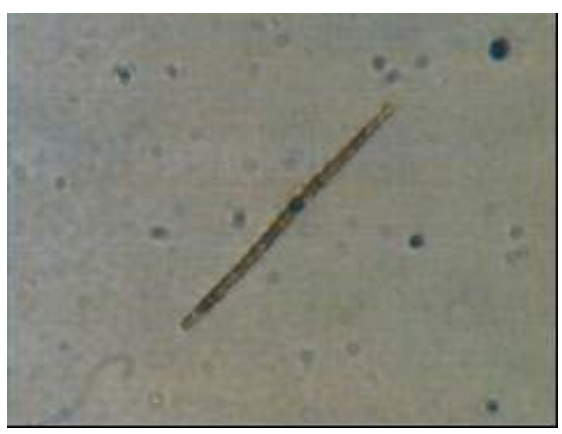

b

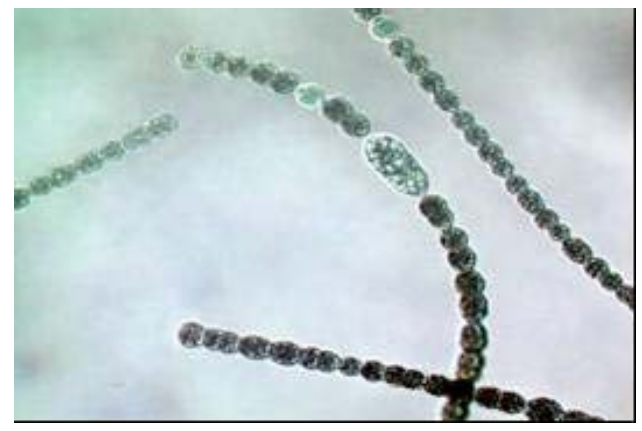

C

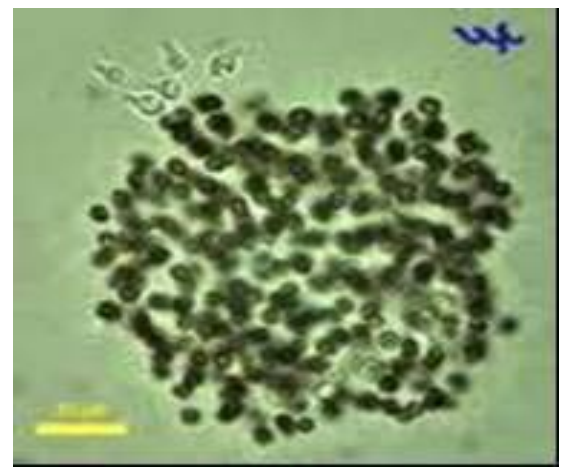

Figuras 10. Espécies de algas encontradas nas amostras de água do viveiro das duas coletas: Pseudanabaena mucicola (a), Anabaena circinalis (b) e Microcystis aeruginosa (c). Todas são cianobactéria tóxicas de água doce, (Falconer, 2004). 
Tabela 9. Composição (divisão, gênero ou espécie) do fitoplâncton/bacterioplâncton identificados no viveiro das duas coletas de água.

\begin{tabular}{|c|c|c|}
\hline Divisão & Gênero & Espécie \\
\hline \multirow{6}{*}{ BACYLARIOPHYCEAE } & Aulacoseira & Aulacoseira granulata \\
\hline & & Aulacoseira ambigua \\
\hline & Cymbella & Cymbella sp. \\
\hline & Eunotia & Eunotia ssp. \\
\hline & Pinnularia & Pinnularia ssp. \\
\hline & Rhaicosphenia & Rhaicosphenia sp. \\
\hline \multirow{18}{*}{ CYANOPHYTA* } & Anabaena & Anabaena circinalis \\
\hline & & Anabaena spiroides \\
\hline & Aphanocapsa & Aphanocapsa sp. \\
\hline & Aphanothece & Aphanothece sp. \\
\hline & Coelomorum & Coelomorum sp. \\
\hline & Cyanodictium & Cyanodictium \\
\hline & Gloeocapsa & Gloeocapsa sp. \\
\hline & Hormothece & Hormothece sp. \\
\hline & Limnothrix & Limnothrix sp. \\
\hline & Merismopedia & Merismopedia tenuissima \\
\hline & Microcystis & Microcystis aeruginosa \\
\hline & & Microcystis panniformis \\
\hline & & Microcystis viridis \\
\hline & & Microcystis cf. wesenbergii \\
\hline & Pseudanabaena & Pseudanabaena mucicola \\
\hline & Sphaerocavum & Sphaerocavum brasiliensis \\
\hline & Sphaerocystis & Sphaerocystis sp. \\
\hline & Whoronichinia & Whoronichinia sp. \\
\hline \multirow{14}{*}{ CHLOROPHYTA } & Coelastrum & Coelastrum sp. \\
\hline & Cosmarium & Cosmarium sp. \\
\hline & Desmodesmus & Desmodesmus armatus \\
\hline & Gloecytis & Gloecytis ampla \\
\hline & Isthmochloron & Isthmochloron sp. \\
\hline & Kirchineriela & Kirchineriela sp. \\
\hline & Pediastrum & Pediastrum duplex \\
\hline & Quadrigula & Quadrigula sp. \\
\hline & Staurastrum & Staurastrum gracile \\
\hline & Scenedesmus & Scenedesmus acutus \\
\hline & & Scenedesmus opoliensis \\
\hline & & Scenedesmus acuminatus \\
\hline & Staurodesmus & Staurodesmus sp. \\
\hline & Volvox & Volvox aureus \\
\hline CHRYSOPHYCEAE & Dinobryon & Dinobryon sp. \\
\hline DINOPHYCEAE & Peridinium & Peridinium \\
\hline
\end{tabular}


De acordo com a análise quantitativa do fitoplâncton (Tabela 10) verificou-se que as cianobatérias dominaram a comunidade fitoplanctônica. De acordo com os dados observados, M. aeruginosa foi uma das espécies dominantes no dia 27 de maio de 2007, seguida pela $P$. mucicola. Contudo, deve-se reforçar que as espécies pertencentes à classe Bacylariophyceae, tal como a Aulacoseira granulata também foram dominantes nesta primeira amostra e muito abundantes na segunda $(19 / 08 / 2007)$.

De acordo com Eler (2000), nos viveiros do CEPTA/IBAMA com maior densidade de peixes e menor renovação de água a presença de cianobatérias foi alta e, como consequência, foi observada mortandade de peixes. As espécies dominantes foram M. aeruginosa e Cylindrospermopsis raciborskii. Os peixes apresentavam dificuldades para respirar, boca protrátil e alguns com pequenos pontos hemorrágicos.

De acordo com a resolução do CONAMA 357/2005 o número da densidade máxima de cianobatérias sem riscos em ambientes destinados a proteção das comunidades aquáticas, ao abastecimento e consumo humano, bem como a aqüicultura e atividade de pesca é de $20.000 \mathrm{cel} / \mathrm{ml}$ ou $2 \mathrm{~mm}^{3} / \mathrm{L}$. Neste trabalho foram encontrados densidades entre $412.620 \mathrm{org} / \mathrm{ml}$ (27 de maio) e $559.060 \mathrm{org} / \mathrm{ml}$ (19 de agosto). Estes níveis encontrados mostraram-se acima do recomendado pela Legislação em cerca de 21 vezes no dia 27 de maio e, culminado com 27 vezes acima, no dia 19 de agosto. 
Tabela 10. Presença de cianobactérias nas amostras de água do viveiro das duas coletas de água.

\begin{tabular}{|c|c|c|}
\hline \multirow{2}{*}{ Taxa } & \multicolumn{2}{|c|}{ № $\mathrm{org} / \mathrm{ml}$} \\
\hline & $27 / 05 / 2007$ & $19 / 08 / 2007$ \\
\hline Anabaena circinalis & $281^{R}$ & $126.563^{\mathrm{D}}$ \\
\hline Aulacoseira ambígua & $63.563^{\mathrm{MA}}$ & $4063^{R}$ \\
\hline Aulacoseira granulata & $624.094^{\mathrm{D}}$ & $109.688^{\mathrm{MA}}$ \\
\hline Dinobryon sp. & $1.406^{\mathrm{C}}$ & - nO \\
\hline Microcystis aeruginosa (Kütz.) Kütz & $142.844^{\mathrm{D}}$ & $29.688^{A}$ \\
\hline Pseudanabaena mucicula (Hub.-Pest. \& Naumann) Schwabe & $255.875^{\mathrm{D}}$ & $200.313^{\mathrm{D}}$ \\
\hline Scenedesmus opoliensis P. Richt. & $6.344^{\mathrm{A}}$ & $938^{\mathrm{R}}$ \\
\hline Concentração de clorofila-a em $\mu \mathrm{g} / \mathrm{L}$ & 2474,73 & 1444,89 \\
\hline \multicolumn{3}{|c|}{ Presença de cianobactéria nas amostras } \\
\hline Anabaena circinalis & 281 & 126.563 \\
\hline Anabaena spiroides & 4.219 & - \\
\hline Aphanocapsa sp. & 750 & 2.188 \\
\hline Aphanothece sp. & 281 & - \\
\hline Coelomorum sp. & 281 & - \\
\hline Cyanodictium sp. & 750 & - \\
\hline Gloeocapsa sp. & 281 & 187.813 \\
\hline Hormothece sp. & 2.810 & - \\
\hline Limnothrix sp. & 531 & - \\
\hline Merismopedia tenuissima & 281 & - \\
\hline Microcystis aeruginosa & 142.844 & 29.688 \\
\hline Microcystis panniformis & 281 & 281 \\
\hline Microcystis viridis & 656 & - \\
\hline Microcystis cf. wesenbergii & 531 & - \\
\hline Pseudanabaena mucicola & 255.875 & 200.313 \\
\hline Sphaerocavum brasiliensis & 156 & 11.563 \\
\hline Sphaerocystis sp. & 687 & - \\
\hline Whoronichinia sp. & 1125 & 938 \\
\hline Número total Cianobactérias (org/ml) & 412.620 & 559.066 \\
\hline
\end{tabular}

D = Espécie dominante; MA = Espécie muito abundante; $\mathrm{A}$ = Espécie abundante; $\mathrm{C}$ = Espécie comum de ocorrência na amostra; $\mathrm{R}$ = espécie rara na amostra; $\mathrm{NO}^{\circ}$ = espécie que não ocorreu na amostra. 


\section{3 Microcistinas nas amostras das duas coletas de água}

Os resultados demonstraram a presença de microcistinas nas amostras de água das duas coletas do empreendimento de piscicultura Santa Luzia, localizado em Espírito Santo do Pinhal/SP. Pode-se verificar a detecção de microcistina-LR nos extratos com valores elevados (Tabela 11 e Figura 11). A presença de microcistina nas amostras coletadas pode ser explicada pela ocorrência de florescimentos de cianobactérias, durante as ocasiões das coletas, estas foram representadas principalmente pelas espécies Anabaena circinalis, Anabaena spiroides, Aphanocapsa sp., Microcystis aeruginosa, Microcystis panniformis, Microcystis viridis, e Microcystis cf. wesenbergii

Tabela 11. Presença de microcistina detectadas na água das duas campanhas de coletas.

\begin{tabular}{lcc}
\hline Local & Periodo & Níveis detectados $(\mu \mathrm{g} / \mathrm{mg})$ \\
\hline Santa Luzia & $27 / 05 / 2007$ & 229,2 \\
& & \\
& $19 / 08 / 2007$ & 147,4 \\
\hline
\end{tabular}

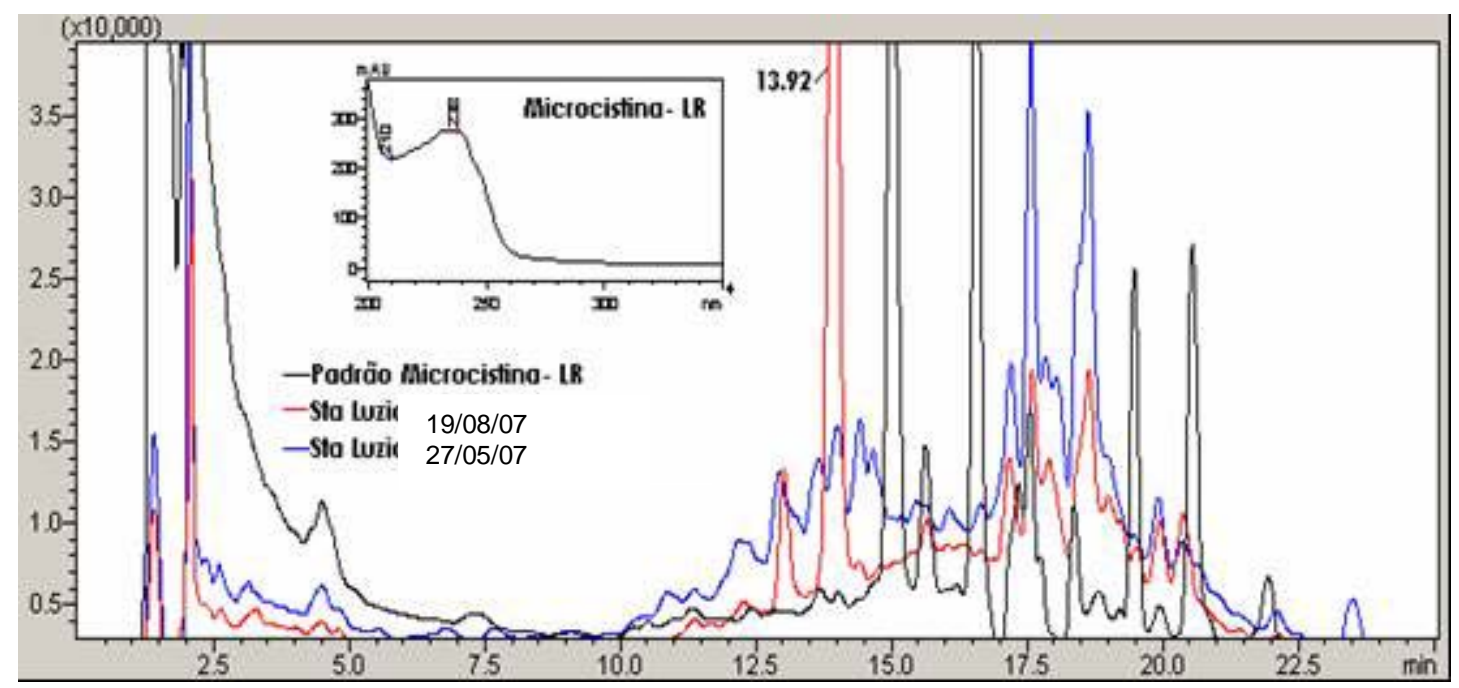

Figura 11. Perfil cromatográfico e espectrofotométrico de microcistina-LR das amostras analisadas durante o estudo. 
Eler et al. (2006) observaram concentração de microcistina-LR de $242 \mu \mathrm{g} / \mathrm{mg}$ (peso seco/p.s.) em amostra de água coletadas em viveiro de criação de peixes no mesmo estabelecimento, durante a ocorrência de florescimento de cianobactérias com dominância de Microcystis aeruginosa, M. panniformis e Anabaena spiroides.

Um aspecto que deve ser considerado é o potencial de biacumulação das cianotoxinas (microcistinas) no tecido do pescado. A exemplo desta possibilidade destacam-se estudos realizados por Sipiä et al. (2001) na região do Mar Báltico que constataram a bioacumulação de nodularinas no músculo de pescado comercializado na região, com níveis máximos de $140 \mu \mathrm{g} / \mathrm{kg}$. Buynder et al. (2001) constataram o efeito de bioacumulação dessa mesma cianotoxina no pescado durante florescimento de cianobactérias tóxicas nos Lagos Gippsland (Austrália), com níveis variando de $250 \mu \mathrm{g} / \mathrm{kg}$ no músculo de pescado, $1.100 \mu \mathrm{g} / \mathrm{kg}$ em camarões e $1.500 \mu \mathrm{g} / \mathrm{kg}$ em moluscos. Essa capacidade de bioacumulação de cianotoxinas foi verificada em estudos realizados por Vasconcelos (1999) em Portugal, em peixes da família Cyprinidae, cujos níveis detectados de microcistinas atingiram valores máximos de $280 \mu \mathrm{g} / \mathrm{kg}$. Experimento realizado por Xie et al. (2004) com carpa prateada (Hypophthalmichthys molitrix) demonstraram a capacidade dessa espécie de peixe em bioacumular microcistinas em regiões diferenciadas do corpo sem haver riscos de letalidade.

No Brasil, alguns estudos reportam este efeito de transferência de cianotoxinas na cadeia trófica, como o de Magalhães et al. (2003) que verificaram a contaminação e bioacumulação de microcistina em peixes e crustáceos durante eventos de florações tóxicas de cianobactérias na Baía de Sepetiba e na Lagoa de Jacarepaguá, ambas localizadas no Estado do Rio de Janeiro. Segundo Magalhães et al. (2003), os níveis máximos de microcistinas bioacumulados registrados em crustáceos 103,3 $\mu \mathrm{g} / \mathrm{g}$ e em peixes $39,6 \mu \mathrm{g} / \mathrm{g}$ na Baía de Sepetiba foram superiores ao limite aceitável na ingestão diária total que é de $0,04 \mu \mathrm{g} / \mathrm{kg}$ de peso corpóreo (Chorus e Bartram, 1999).

Os peixes submetidos aos bioensaios, matrinxã (Brycon cephalus) e tilápia nilótica (Oreochromis niloticus), apresentaram comportamento letárgico após a injeção intraperitoneal. Os exemplares injetados com o extrato de floração apresentaram comportamento letárgico por um período de 10 minutos no decorrer do experimento com as duas espécies após a injeção intraperitoneal. Decorridas 
algumas horas retornaram a seus movimentos normais, e em cada dosagem, até o final de 24 horas, não foram observadas mortandades. Contudo, não foi possível obter um cálculo da dose letal ( $\mathrm{DL}_{50}-24 \mathrm{hs}$ ) sobre os ensaios que demonstrassem efeito tóxico considerado.

A produção de toxinas por cianobactérias pode ter importância ecológica muito grande, devido a seu potencial impacto, afetando desde o nível do piconanoplanctônico até nivéis tróficos superiores (Chorus e Bartram, 1999). Associada a essa problemática agrega-se a preocupante possibilidade de as cianotoxinas serem bioacumuladas nos organismos superiores da cadeia alimentar aquática (Vasconcelos, 1999, Buynder et al., 2001; Sipiä et al., 2001; Magalhães et al., 2003).

As toxinas de cianobactérias, em especial hepatotoxinas do tipo microcistinaLR, têm sido descritas como causadoras das intoxicações e morte de peixes (Rabergh et al., 1991; Rodger et al., 1994; Phillips, et al., 1995; Zimba et al., 2001; Eler et al., 2006, 2009).

Meletti (2003) relata que em condições de laboratório as espécies Serrapinnus notomelas (Characiformes, Characidae) expostas ao teste de toxicidade do efluente de indústria de papel e celulose de sedimento coletados em vários rios da bacia do rio Piracicaba, não ocorreu mortandade, mas sim alterações histológicas nos tecidos analisados.

Eler et al. (2006) verificaram que o batimento opercular de Brycon cephalus foi intenso nos peixes injetados com os extratos algáceos na primeira hora após a administração (injeção intraperitoneal). Contudo, os peixes com doses de 500 e $1.000 \mathrm{mg} / \mathrm{kg}$ interrompiam rapidamente o comportamento de letargia com movimentos de natação erráticos e frenéticos e começaram a morrer depois de duas horas o que difere dos resultados encontrados em nosso trabalho.

No presente trabalho a necrópsia revelou que os peixes eutanasiados após as 24 horas de teste apresentavam excesso de muco no opérculo e na pele. Foi constatado que alguns peixes estavam debilitados com alguns lugares do corpo sem escamas principalmente o matrinxã que é uma espécie extremamente agitada, e com as nadadeiras um pouco danificadas. As brânquias e os fígados dos exemplares testados apresentaram-se pálido com coloração rósea. Estes dados são semelhantes ao reportados em um estudo realizado por Eler et al. (2009) com bioensaios de toxicidade de extratos algáceos em Brycon cephalus. O fígado 
apresentou-se vermelho pálido em todos os animais em exposição aos extratos algáceos das duas espécies testadas. Observou-se a presença da vesícula biliar verde-escuro e túrgida com aumento de volume significativo em todos os tratamentos para as duas espécies nos testes (125 a 1.000 mg/kg) em relação ao controle que se apresentava na coloração verde-claro. O rim apresentou coloração vermelho escuro e a sua retirada e dissecação foi um trabalho difícil devido a sua consistência. 


\section{4 Testes de toxicidade}

\section{a) Teste ecotoxicológico com cepa de Microcystis aeruginosa}

Os peixes injetados com extratos liofilizados da Microcystis aeruginosa apresentaram comportamento letárgicos por períodos prolongados, com breves momentos realizando natação rápida e frenética. A letargia tornou-se mais pronunciada com o tempo e os peixes evitaram o alimento. Além disso, os exemplares submetidos ao bioensaio perderam a coordenação e a flutuabilidade com o passar do tempo. Observou-se que este comportamento foi mantido nos grupos expostos as dose de 250, 500 e $1.000 \mathrm{mg} / \mathrm{kg}$. Os peixes em estado terminal apresentavam-se com movimentos ventilatórios operculares acelerados e diminuíam gradualmente a frequência desses batimentos até próximo do óbito. Embora os peixes que receberam as menores doses 125 e $250 \mathrm{mg} / \mathrm{kg}$ mantivessem o movimento ventilatório opercular ao longo do período do bioensaio continuaram nadando com dificuldades.

Os dados obtidos foram semelhantes aos encontrados por Eler et al. (2006, 2009) em coleta de água feita em pesque-pague, onde essas águas foram liofilizadas (extrato algáceo) e injetadas intraperitoneal em Brycon cephalus e logo nas primeiras horas foram observados movimentos do operculares acelerados.

Foi constatado que os animais da dosagem de $1.000 \mathrm{mg} / \mathrm{kg}$ estavam moribundos 30 minutos após o início do experimento, com batimento opercular intenso, perda de escamas e 60 minutos após o tratamento os peixes afundaram e chegaram a óbito.

Os resultados da dissecação apontam o efeito da microcistina-LR sobre 0 fígado, rins e brânquias dos indivíduos submetidos aos tratamentos, de acordo com a dosagem do extrato da Microcystis aeruginosa administrado. No caso da vesícula biliar, por exemplo, a coloração apresentada era de um verde-escuro e com volume aumentado. A Tabela 12 apresenta os resultados da dissecção dos animais mortos no decorrer do experimento durante as 24 horas de teste. 
Tabela 12. Exemplares de matrinxã (Brycon cephalus) mortos durante 24 horas de bioensaio com Microcystis aeruginosa cultivada em laboratório.

\begin{tabular}{cccccc}
\hline $\begin{array}{c}\text { Dosagem } \\
\mathbf{m g} / \mathbf{k g}\end{array}$ & $\begin{array}{c}\text { Peso total } \\
\mathbf{( g )}\end{array}$ & $\begin{array}{c}\text { Comprimento Total } \\
\mathbf{( c m})\end{array}$ & $\begin{array}{c}\text { Fígado } \\
\mathbf{( g )}\end{array}$ & $\begin{array}{c}\text { Rins } \\
\mathbf{( g )}\end{array}$ & $\begin{array}{c}\text { Brânquia } \\
\mathbf{( g )}\end{array}$ \\
\hline 250 & 26,60 & 12,7 & 0,3598 & 0,1087 & 1,0033 \\
500 & 21,55 & 11,9 & 0,3628 & 0,0739 & 0,6487 \\
500 & 19,77 & 11,4 & 0,2209 & 0,0635 & 0,8598 \\
1.000 & 20,86 & 11,6 & 0,2562 & 0,0327 & 0,7206 \\
1.000 & 20,87 & 11,7 & 0,2572 & 0,0337 & 0,7216 \\
1.000 & 26,21 & 11,9 & 0,3812 & 0,0482 & 0,7258 \\
1.000 & 18,94 & 11,5 & 0,2862 & 0,0403 & 0,3772 \\
1.000 & 23,84 & 12,1 & 0,2250 & 0,0572 & 0,9542 \\
\hline
\end{tabular}

Obs.: Todos os indivíduos mortos encontravam-se com vesícula verde-escura

O comportamento letárgico nesses dois tratamentos (500 e $1.000 \mathrm{mg} / \mathrm{kg}$ ) tornou-se mais pronunciado com o decorrer do tempo pós-injeção intraperitoneal. Todos os peixes do tratamento com concentração de $1.000 \mathrm{mg} / \mathrm{kg}$ morreram em diferentes intervalos de tempo (1, 3, 8 e 12 horas) após a injeção intraperitoneal. A dose letal $\left(D_{50}-24 \mathrm{~h}\right)$ ao final do teste foi de $312,82 \mathrm{mg} / \mathrm{kg}$ de peso corpóreo. Os peixes do controle e os sobreviventes nos tratamentos foram eutanasiados após 24 horas do início do bioensaio para exame histopatológico.

Os peixes mortos pela ação dos extratos algáceos de Microcystis aeruginosa apresentavam muco no opérculo e na pele. Foi constatado que as brânquias e fígado apresentaram-se pálido com coloração rósea. Os rins apresentaram coloração vermelho escuro, enquanto a vesícula biliar estava túrgida e com coloração verde-escuro, nossos resultados foram semelhantes aos encontrados por (Eler et al., 2006; 2009) expondo Brycon cephalus a amostras de extrato algáceo coletadas em pesque-pague. 


\section{Análises histológicas dos tecidos afetados com extrato de Microcystis aeruginosa}

As alterações histológicas do tecido hepático e das dosagens seguidos dos seus estágios encontram-se descritas nas Tabelas 13 e 14.

O exame histopatológico do tecido hepático de exemplares de matrinxã (Brycon cephalus) do controle (Figura $12 \mathrm{a}, \mathrm{b}$ ), apresentou com aspecto normal o epitélio hepático (HP) e da veia central (VC). Nos animais expostos nas dosagens 250, 500 e mortos com concentração de 1.000 mg/kg durante o período de 24 horas, foi observada a presença de vacúolos (V); a seta mostra o ducto biliar (DB) alterado, gordura (GORD) e (CONGESTÃO) (Figura 12 d, e, f). Na dose de 125 mg/kg embora não houve mortandade foi observado o ducto biliar (DB) alterado (Figura 12 c).

Tabela 13. Alterações histológicas consideradas na análise do tecido hepático de matrinxã (Brycon cephalus) exposto a Microcystis aeruginosa. O estágio considerado para cada alteração está indicado na segunda coluna. Baseado em Rigolin-Sá (1998), adotado por Meletti (2003) método ajustado e adaptado no presente trabalho.

\begin{tabular}{lc}
\hline \multicolumn{1}{c}{ ALTERAÇÕES HISTOLÓGICAS } & ESTÁGIO \\
\hline \multicolumn{1}{c}{ Alterações nos hepatócitos } & $\mathrm{I}$ \\
\hline Desarranjos dos cordões hepáticos & $\mathrm{I}$ \\
Perda ou atipia do contorno celular & $\mathrm{I}$ \\
Perda ou atipia do contorno nuclear & $\mathrm{I}$ \\
Aumento do volume celular & $\mathrm{II}$ \\
Aumento do volume nuclear & $\mathrm{I}$ \\
Intensa vacuolização citoplasmática & $\mathrm{II}$ \\
Vacuolização nuclear &
\end{tabular}


Tabela 14. Alterações histológicas do tecido hepático dos matrinxãs (Brycon cephalus) expostos a Microcystis aeruginosa.

\begin{tabular}{|c|c|}
\hline Doses (mg/kg) & Estágio \\
\hline Controle & 0 \\
\hline 125 & 1 \\
\hline 250 & 1 \\
\hline 500 & II \\
\hline 1.000 & II \\
\hline
\end{tabular}


a

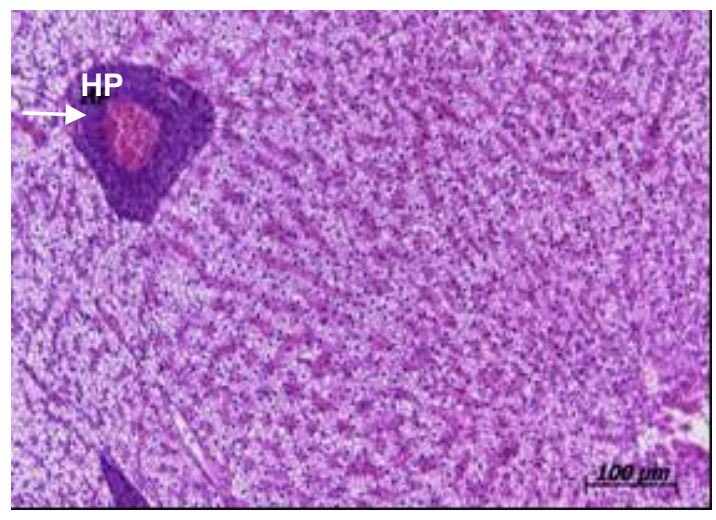

C

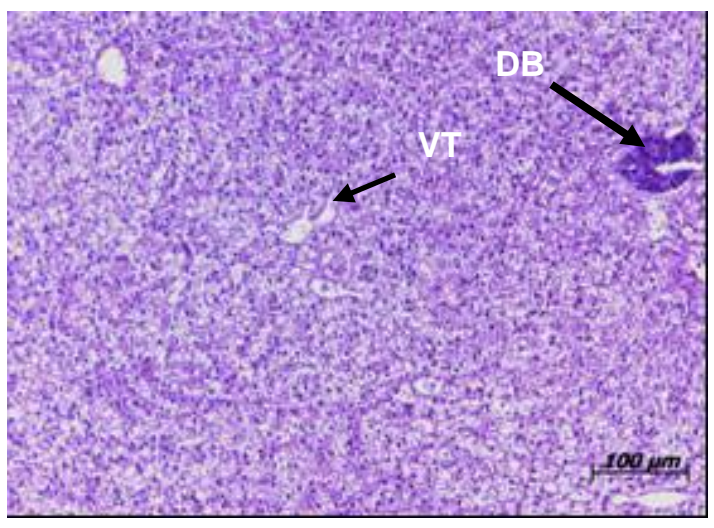

e

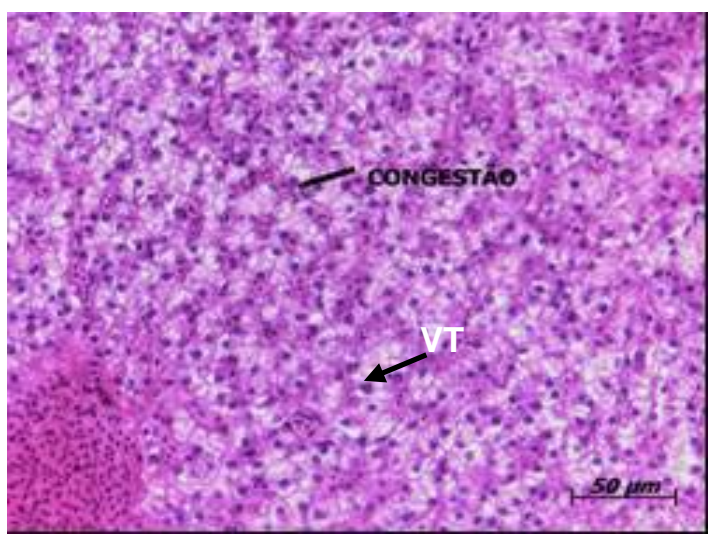

b

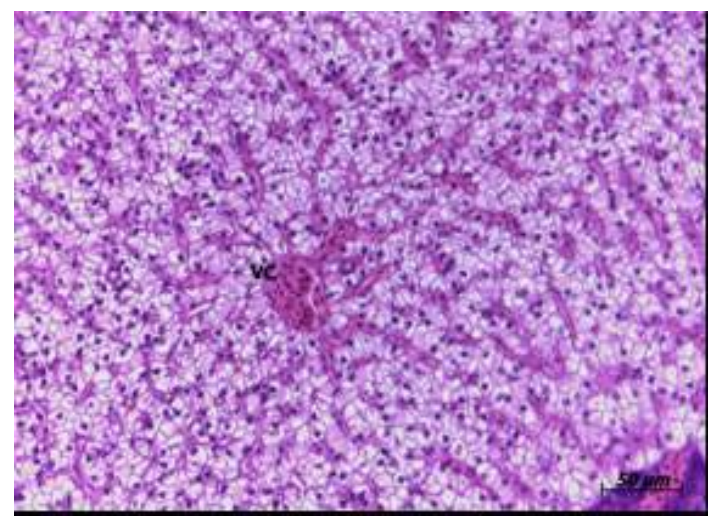

d

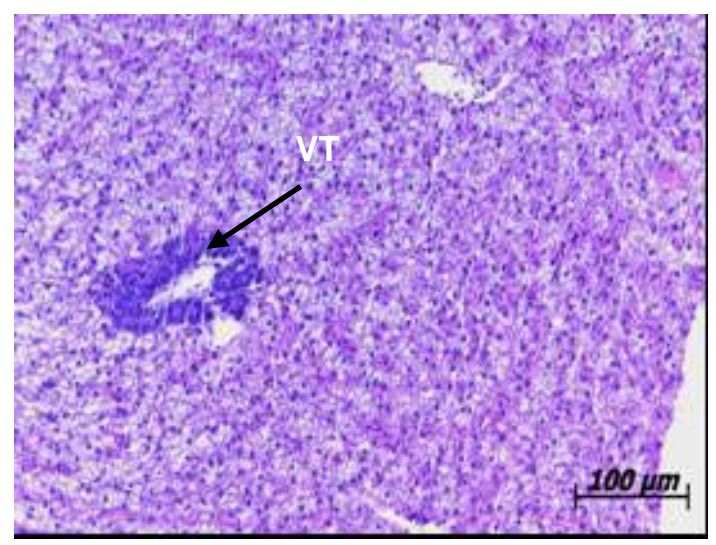

f

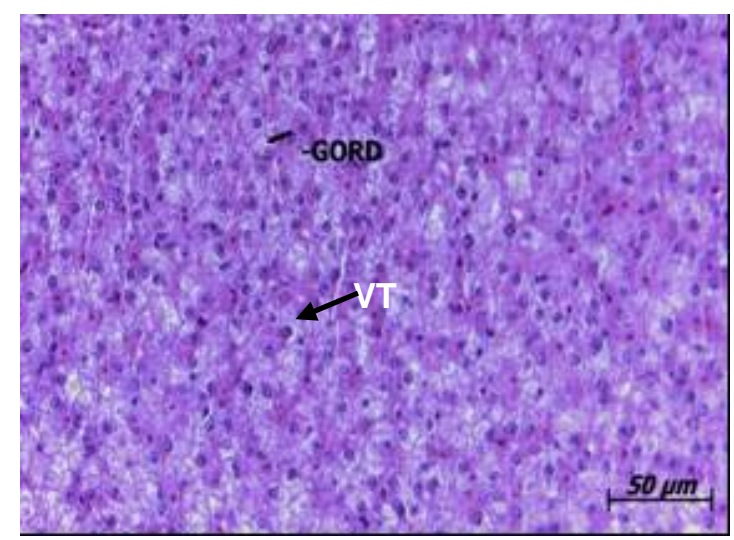

Figura 12 Análise histológica do tecido hepático de exemplares de matrinxã (Brycon cephalus) do controle (a), (b) com aspecto normal do epitélio hepático (HP) e da veia central (VC). Tratamento das doses de 125 (c), 250 (d), 500 (e) e 1.000 mg/kg (f), a seta mostra a presença vacuolização do túbulo (VT), Ducto biliar (DB) moderadamente vacuolizado, Esteatose e (CONGESTÃO). Escala: (40-1300x1030S) (HE, $6 \mu \mathrm{m})$.

Azevedo et al. (2006) verificaram que a intoxicação envolvendo cianobactéria causado por hepatoxinas, que apresentam ação mais lenta, causando a morte entre 
poucas horas e poucos dias, em decorrência de hemorragia intra-hepática e choque hipovolêmico (aumento excessivo do fígado). As hepatoxinas chegam ao fígado por meio de receptores dos ácidos biliares e promovem desorganização dos filamentos intermediários e dos filamentos de actina, que são polímeros protéicos componentes do citoesqueleto. Essa desorganização leva a uma retração dos hepatócitos, provocando a perda de contato entre eles e as células que formam os capilares sinusoidais. Como consequência o fígado perde sua arquitetura e desenvolve graves lesões internas.

Segundo Landsberg (2002), as cianobactéria são descritas em trabalhos como potencialmente tóxicos aos animais terrestres principalmente as microcistina encontradas também no fígado de animais selvagens, após ingestão de água contaminada. Observou assim que cianobactéria pode produzir ambas microcistina e anatoxinas (Anabaena e Oscillatoria), somente a microcistina pode produzir toxina e causar alterações no tecido hepático dos animais. Os efeitos e consequências das cianobactéria de água doce em sistemas aquáticos são identificados na maioria das vezes no zooplâncton. A ingestão de toxina depende do comportamento e do equilíbrio desta cianobactéria no meio ambiente e bem como a concentração de células na água. O desequilíbrio dessas cianobactéria no meio aquáticos causa uma concorrência entre elas tornando-as mais resistentes ao meio em que vivem, pela liberação de toxina na água causando morte aos organismos aquáticos com menor resistência no meio ambiente.

Impactos agudos causados por algas tóxicas geralmente têm efeito agudo. Quando os organismos são rapidamente expostos a altas concentrações a ao florescimento de algas podem ser observados sintomas semelhantes aos eventos de envenenamento por mariscos, o que significa um problema de saúde publica. Além disso, mortandade em massa de organismos aquáticos pode ocorrer. Exposição a altas concentrações da toxina geralmente promove uma resposta bioquímica ou celular que leva a uma mudança fisiológica, patológica e comportamental aos animais diretamente expostos aos bioprodutos metabólicos; o que poderá responder em diferentes modos ou caminhos para evitar ou minimizar os efeitos tóxicos (Landsberg, 2002; Gumbo et al., 2008)

Uma concentração de massa algal, acima de $20.000 \mathrm{cel} / \mathrm{ml}$ (Resolução 357 do CONAMA/2005), pode ser letal aos organismos aquáticos. Por sua vez em concentrações abaixo do nível pode causar somente uma suave resposta fisiológica, 
patológica ou comportamental. Em alguns casos a exposição por cianotoxinas acima de um período prolongado, os organismos podem acumular toxina até que eles excedam a concentrações toleráveis, ocasionando então aos organismos possíveis efeitos crônicos. A extensão no qual os organismos irão acumular essas toxinas depende dessa solubilidade (hidrofílica ou lipossolúvel), da estabilidade e toxicocinético da toxina. Tolerância fisiológica de espécies de indivíduos a varias toxinas irá também determinar o nível de acumulo da toxina (Landsberg, 2002)

Kankaanpää et al. (2002) estudaram o efeito de bioacumulação de nodularina encontrada na espécie Nodularia spumigena e, coletada no mar Báltico. O material liofilizado foi incorporado em ração comercial peletizada e administrada a truta (Salmo trutta m. trutta L.) por via oral em dose única com uma concentração de 125 $\mathrm{mg} / \mathrm{kg}$. A duração do teste foi de 8 dias em condições de laboratório. O objetivo dos autores era a verificação do acumulo dessas no fígado da truta, visto que a nodularina é uma hepatoxina de pentapepitideos cíclicos. Além do teste biológico duas técnicas de análise química foram efetuadas para a detecção do produto, a saber, pelo método de cromatografia líquida de alta eficiência (HPLC) e pelo método de imunoensaio Elisa. Os autores concluíram que a bioacumulação da nodularina ocorre de forma lenta do fígado para o intestino do animal, além disso, o composto sofre alterações em sua composição química antes de 24 horas. Os danos causados nos intestinos e fígados dos sobreviventes foram reversíveis. Concluíram, ainda, que a importância ecologica do florescimento de algas no mar Báltico é de extrema importância, principalmente pelas áreas destinadas a criação intensiva de peixes.

Segundo Fischer e Dietrich (2000), verificando mudanças bioquímicas associada com patologia da carpa (Cyprinus carpio) em teste de laboratório por 72 horas, com carpas alimentadas via oral pelo sistema gavagem com uma dose de 400 $\mu \mathrm{g}$ de Microcystis aeruginosa MC-LR/kg de peso corpóreo. As análises histológicas evidenciaram alterações caracterizadas no hepatopâncreas por uma dissociação dos hepatócitos, início de apoptose celular. 
O exame histopatológico do tecido renal de exemplares de juvenis de matrinxã (Brycon cephalus) do controle dos Túbulos ( $T$ ) e Glomérulos normais ( $G$ ) aspecto normais de animais saudáveis (Figura $13 \mathrm{a}, \mathrm{b}$ ).

Nos rins dos peixes submetidos aos tratamentos das dosagens de 125, 250, 500 e $1.000 \mathrm{mg} / \mathrm{kg}$ (Figura $13 \mathrm{c}, \mathrm{d}, \mathrm{e}, \mathrm{f}$ ) foram observadas alterações caracterizadas pela vacuolização dos túbulos (VT), com desorganização dos glomérulos e desintegração tubular seguida de nefrose. Degeneração tubular (DT), degeneração do glomérulo (DG), a vacuolização do túbulo foram mais acentuadas nas dosagens de 500 e $1.000 \mathrm{mg} / \mathrm{kg}$ (Figura 13 e, f).

As Tabelas 15 e 16 destacam o índice de alterações histológicas (IAH) do tecido renal dos dados brutos das alterações patológicas nocivas à espécie estudada Brycon cephalus. O estudo histológico realizado com Microcystis aeruginosa demonstrou degeneração vacuolar alteração observada no epitélio tubular renal dos exemplares expostos. Há tendência de intensificação desta degeneração conforme aumenta a dose de toxina injetada no peixe.

Tabela 15. Alterações histológicas consideradas nas análises de tecido renal de matrinxã (Brycon cephalus) exposto a Microcystis aeruginosa. O estágio considerado para cada alteração está indicado na segunda coluna.

\begin{tabular}{lc}
\hline \multicolumn{1}{c}{ Alterações histológicas } & Estágio \\
\hline Alterações nos glomérulos e túbulos renais & $\mathrm{I}$ \\
\hline Desorganização tubular & $\mathrm{I}$ \\
Desorganização glomerular & $\mathrm{II}$ \\
Degeneração tubular & $\mathrm{II}$ \\
Degeneração glomerular & $\mathrm{II}$ \\
Degeneração citoplasmetica das células tubulares & $\mathrm{II}$ \\
Degeneração nuclear das células tubulares & $\mathrm{I}$ \\
\hline
\end{tabular}


Tabela 16. Alterações histológicas do tecido renal dos matrinxãs (Brycon cephalus) expostos a Microcystis aeruginosa.

\begin{tabular}{|c|c|}
\hline Doses (mg/kg) & Estágio \\
\hline Controle & 0 \\
\hline 125 & I \\
\hline 250 & I \\
\hline 500 & II \\
\hline 1.000 & II \\
\hline
\end{tabular}


a

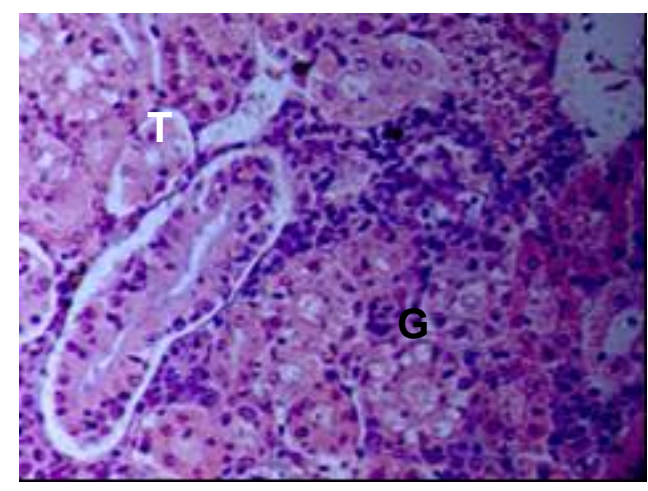

C

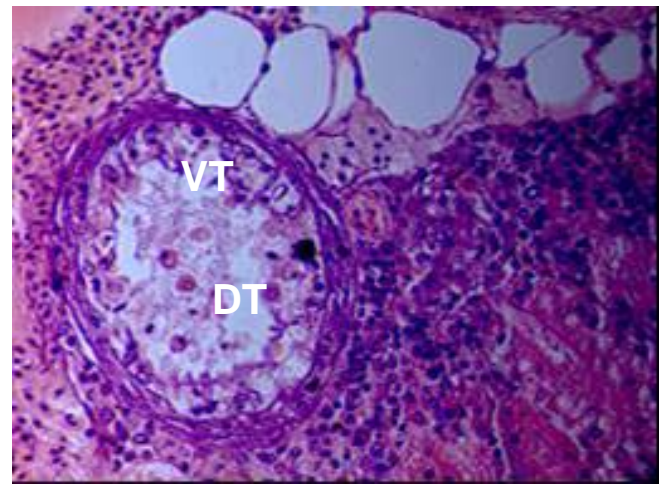

e

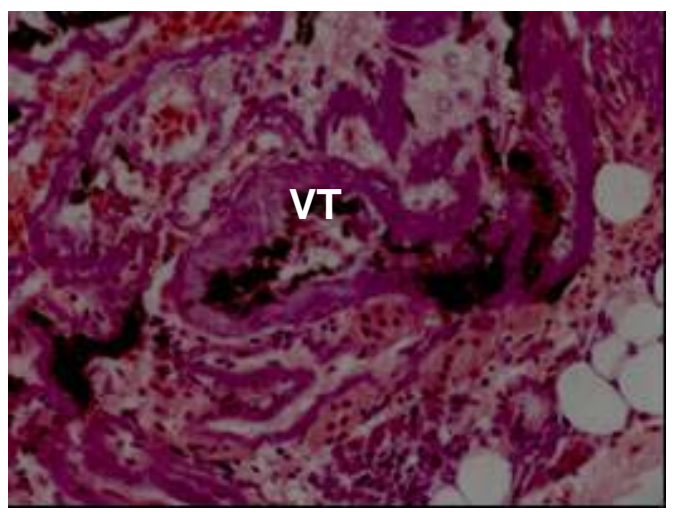

b

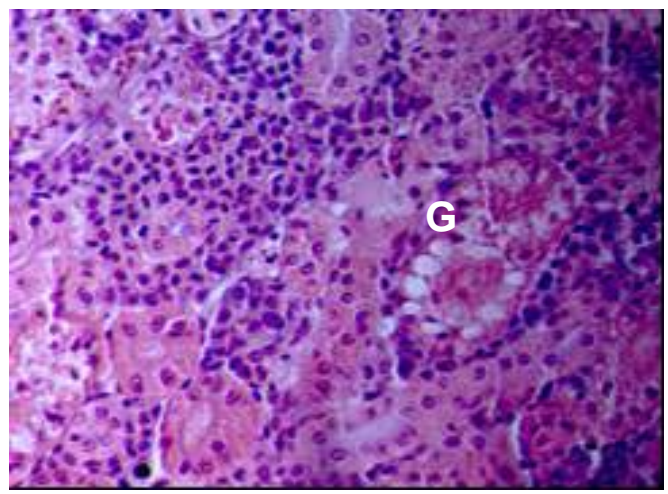

d

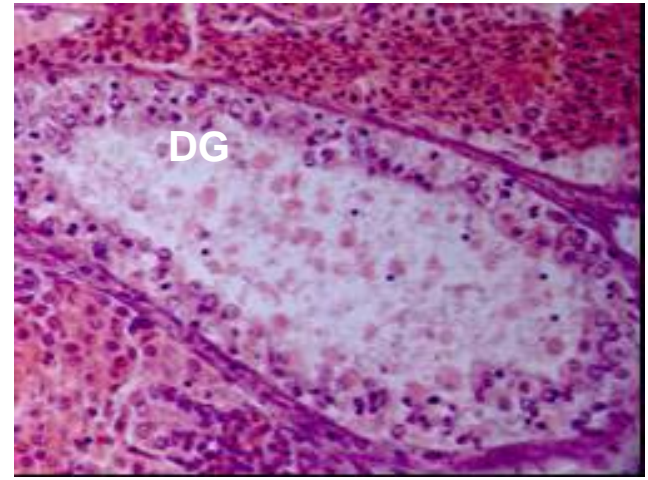

$f$

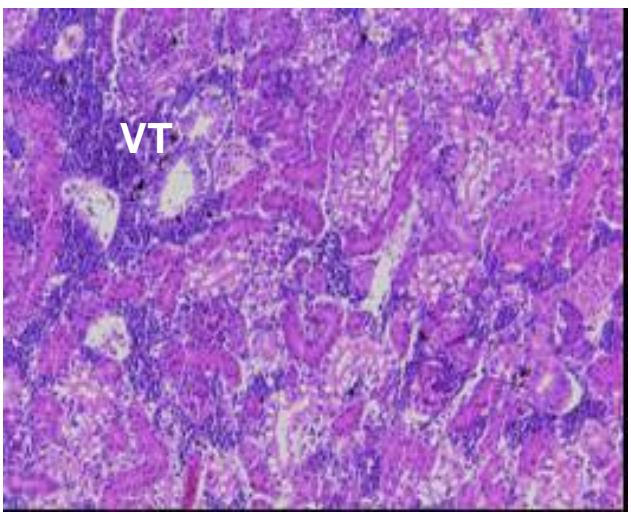

Figura 13 Análise histológica de tecidos renal de exemplares de juvenis de matrinxã (Brycon cephalus) do controle (a), (b) com aspecto normal dos Túbulos (T) e Glomérulos normais (G). Tratamento das doses de 125 (c), 250 (d), 500 (e) e 1.000 $\mathrm{mg} / \mathrm{kg}$ (f), alterações caracterizadas pela vacuolização das células do epitélio (VT), com desorganização dos glomérulos e desintegração tubular seguida de nefrose. Degeneração Tubular (DT), Degeneração do Glomérulo (DG), Vacuolização do túbulo (VT). Escala: (40-1300x1030S) (HE, $6 \mu \mathrm{m})$. 
As análises histológicas evidenciaram danos das células do túbulo, aumento de vacuolização de células epiteliais tubulares, apoptose, hemorragia celular. A mudança degenerativa foi caracterizada por aumento na vacuolização do túbulo, lise celular e esfoliação do tecido epitelial dentro do lumem tubular.

As alterações degenerativas nos tecidos renais (Eler et al., 2006) foram observadas nas análises histológicas em todos os indivíduos testados com extratos algáceos secos liofilizados, com injeção intraperitoneal em Brycon cephalus nas doses de 125, 250, 500 e 1.000 mg/kg de peso corpóreo e duração de 36 horas. Entretanto as alterações severas foram encontradas nos indivíduos mortos durante o bioensaio e no tratamento de $125 \mathrm{mg} / \mathrm{kg}$, em que se observaram caracterizadas pela vacuolização das células do epitélio, com desorganização dos glomérulos e desintegração tubular seguida de nefrose. 
As Tabelas 17, 18 e Figura 14 destacam o índice de alterações histológicas (IAH) do tecido branquial dos dados brutos das alterações seguidas de seus estágios encontradas nos cortes histológicos nos peixes. As análises histológicas realizadas demonstraram que houve o Rompimento Lamelar ( $3^{\circ}$ estágio), Fusão Total de todas as lamelas (Fusão Total é alteração de $2^{\circ}$ estágio), Congestão Sanguínea (entre o aneurisma e a dilatação, fase mais avançada que a dilatação) Célula Cloreto (proliferação alteração iônica desequilíbrio iônico aumento de células) (Hiperplasia aumento), Edema (mudança inflamatória presença de célula cloreto nas lamelas secundárias). Verificou-se que houve uma tendência de intensificação dessas alterações nos órgãos do peixe conforme aumenta-se a dose de toxina (Figuras 14 e $15 \mathrm{c}, \mathrm{d}, \mathrm{e}, \mathrm{f}$ ).

Análise histológica do tecido branquial de exemplares de matrinxã (Brycon cephalus) do controle (Figura 15 a, b) mostrando aspecto normal do Seio Venoso Central (artéria que passa no filamento primário e leva o sangue para os filamentos das artérias secundarias). (SVC), Espaço Estratificado do filamento primário (EE), Lamela Secundária (LS), Espaço interlamelar (Ei).

$\mathrm{Na}$ (Figura 15 c, d, e, f) são apresentadas as alterações das brânquias em todas as dosagens testadas.

Os resultados obtidos neste trabalho são corroborados pelos encontrados por Eler et al. (2006, 2009), realizado por meio de bioensaios de toxicidade com a utilização de extratos algáceos liofilizados coletados em pesque-pague e injetados intraperitonealmente em Brycon cephalus. Esses autores observaram concentração de microcistina-LR de $242 \mu \mathrm{g} / \mathrm{mg}$ (peso seco/p.s.) que foi altamente tóxica para os animais testados, evidenciado nos cortes histológicos alterações severas desde a dosagem de 125 até $1.000 \mathrm{mg} / \mathrm{kg}$, causadas pelo efeito da toxina nos órgãos analisados. 
Tabela 17. Alterações histológicas na análise das brânquias de matrinxã (Brycon cephalus) expostos a Microcystis aeruginosa. O estágio considerado para cada alteração está indicado na segunda coluna.

\section{Alterações histológicas}

Estágio

\section{a)Hipertrofia e hiperplasia do tecido respiratório}

Deslocamento ou elevação das células do epitélio

Hiperplasia das células epiteliais na base das lamelas

secundarias

Hiperplasia das células epiteliais ao longo das lamelas

secundarias

Fusão parcial (na base ou no topo) das lamelas secundárias

I

Fusão completa de algumas lamelas secundárias

Fusão completa de todas as lamelas secundarias

b)Alterações nas células mucosas e cloreto

Hipertrofia e/ou Hiperplasia das células cloreto

Presença de células cloreto nas lamelas secundárias

c)Alterações nos vasos sanguíneos lamelares

Dilatação dos capilares

Congestão vascular

d)Estágio terminal 
Tabela 18. Alterações histológicas no tecido Branquial do matrinxã (Brycon cephalus) expostos a Microcystis aeruginosa.

\begin{tabular}{|c|c|}
\hline Doses (mg/kg) & Estágio \\
\hline Controle & 0 \\
\hline 125 & I \\
\hline 250 & II \\
\hline 500 & II \\
\hline 1.000 & III \\
\hline
\end{tabular}

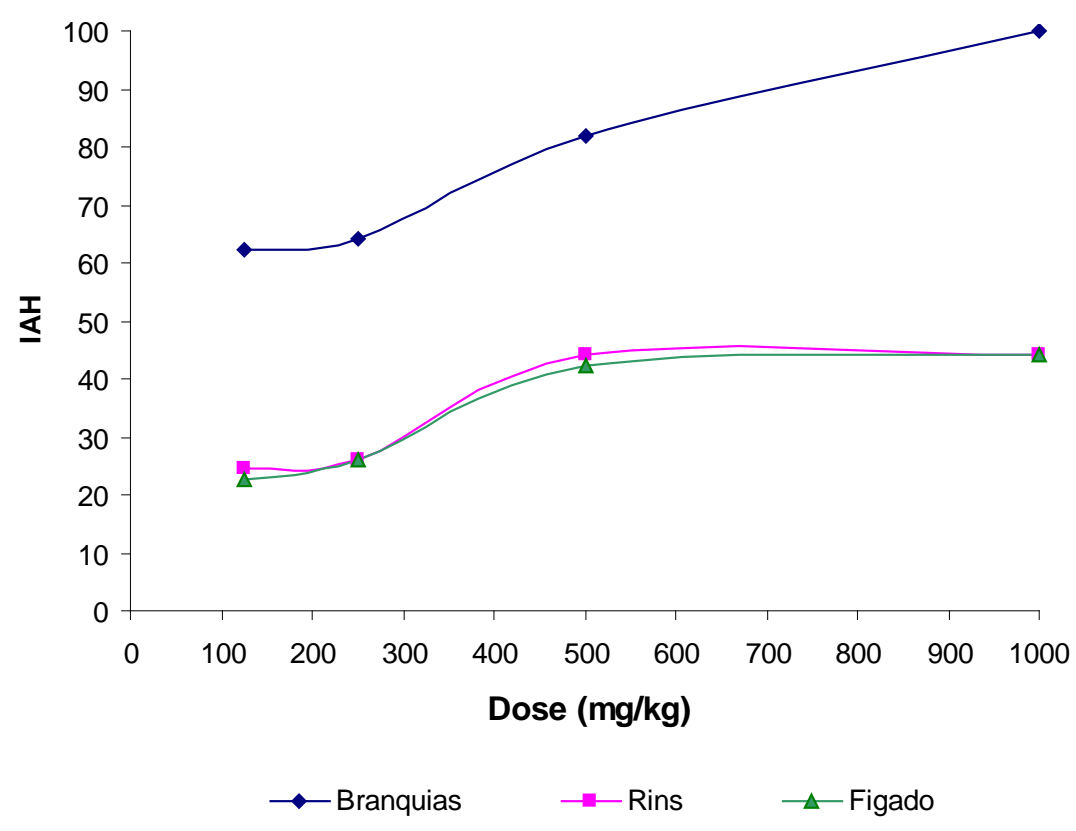

Figura 14. Índice de alteração histológica (IAH) dos órgãos fígado, rins e brânquias dos matrinxãs (Brycon cephalus) expostas à Microcystis aeruginosa. 
a

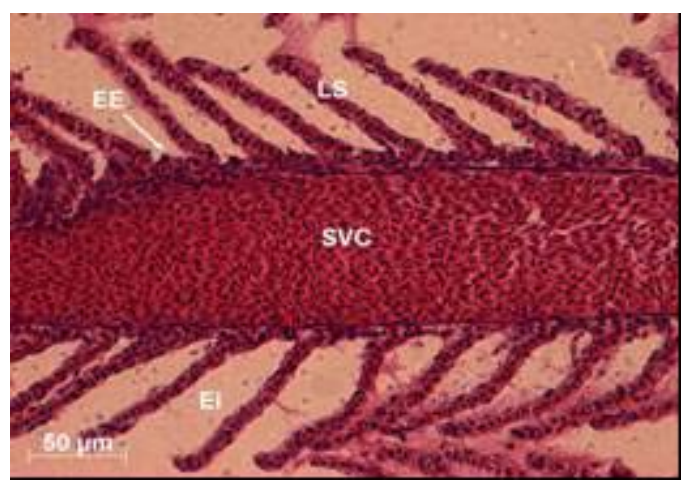

C

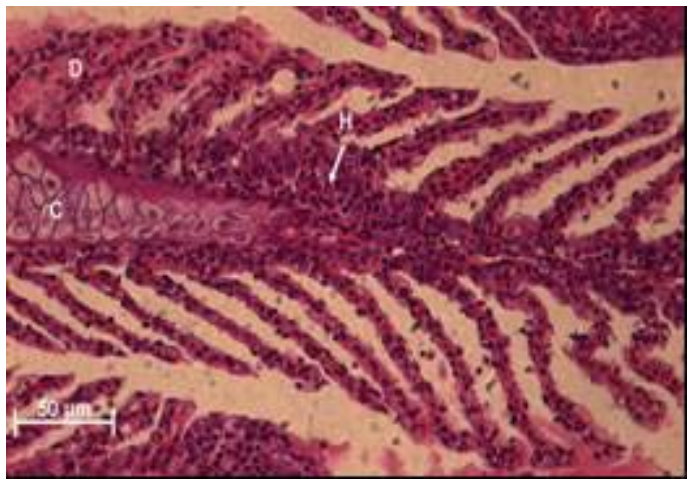

e

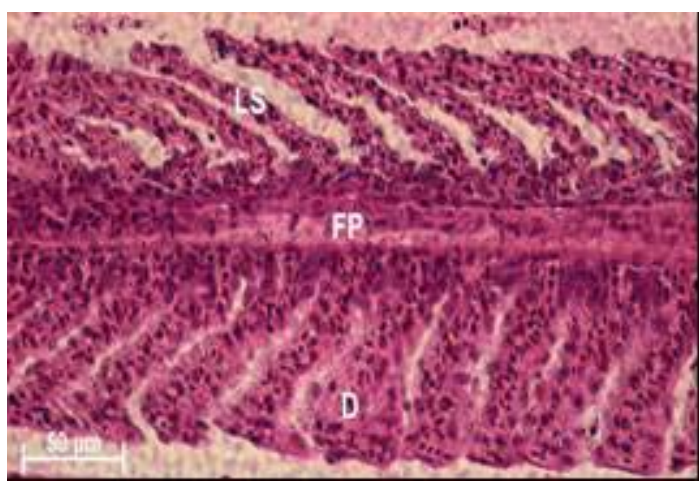

$\mathrm{b}$

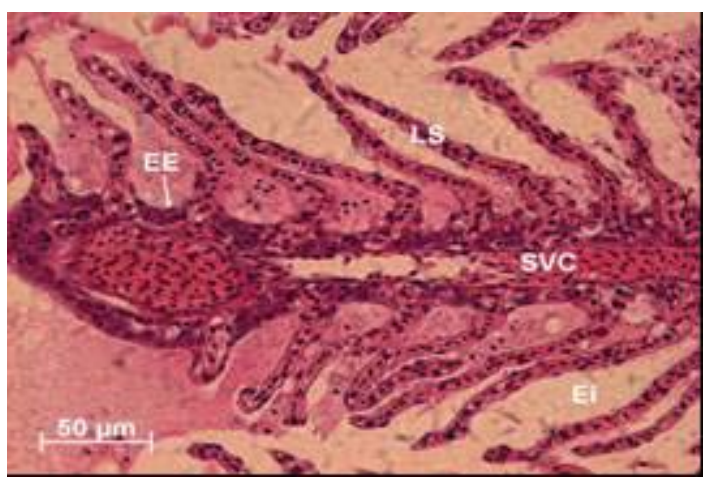

d

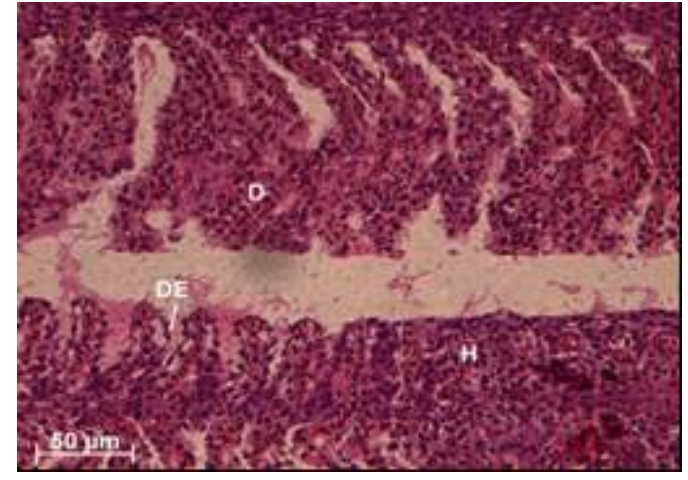

f

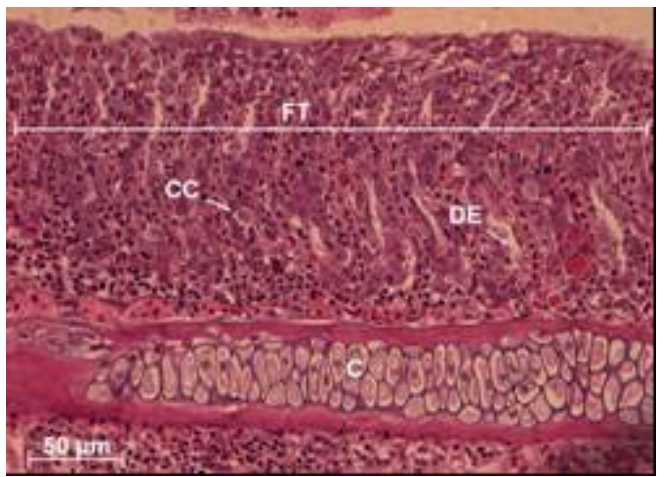

Figura 15 Análise histológica do tecido branquial de exemplares do matrinxã (Brycon cephalus) do controle $(a, b)$ aspecto normal Seio Venoso Central (artéria que passa no filamento primário e leva o sangue para os filamentos das artérias secundarias). (SVC), Espaço Estratificado do filamento primário (EE), Lamela Secundária (LS), Espaço interlamelar (Ei). Tratamento das doses de 125 (c), 250 (d), 500 (e) e 1.000 mg/kg (f), Filamento Primário (FP), Hiperplasia (1º estágio) Confusão total $(H)$, Dilatação (1º estágio) (D), Rompimento Lamelar (30 estágio) (RL), Cartilagens (normais) (C), Deslocamento do Epitélio (DE), Fusão Total de todas as lamelas (Fusão Total é alteração de $2^{\circ}$ estágio) (FT), Congestão Sanguínea (entre o aneurisma e a dilatação, fase mais avançada que a dilatação) (CO), Célula Cloreto (proliferação alteração iônica desequilíbrio iônico aumento de células) (Hiperplasia aumento) (CC), Edema (mudança inflamatória presença de célula cloreto nas lamelas secundárias) (E). Escala: (40-1300x1030S) (HE, $6 \mu \mathrm{m})$. 
Reis et al. (2009) verificaram alterações do epitélio branquial das lamelas de tilápias (Oreochromis niloticus) causadas por mudanças do ambiente aquático em quatro tanques de criação intensiva num pesque-pague da região Noroeste do Paraná. Observaram que os filamentos branquiais de quatro espécimes submetidos a cortes histológicos as lamelas branquiais são os locais onde ocorre a troca efetiva entre elementos químicos do sangue e da água, sobretudo, promovendo a hematose, provavelmente outros componentes do ambiente aquático, eram irritantes para os animais o que forçavam a manter uma área lamelar mais reduzida. Considerando que a concentração de oxigênio dissolvido era cada vez menor com a passagem da água de um tanque para o outro, é razoável considerar que uma ampliação da área das lamelas seja necessária para manter o nível de oxigênio circulante no sangue dos animais. Concluíram que houve um progressivo aumento de alterações morfológicas do epitélio branquial (hiperplasia interlamelar, fusão lamelar e deslocamento epitelial) quando foi verificado nos peixes produzidos em tanques com condições menos favoráveis.

\section{b) Teste ecotoxicológico com extratos de cianobactérias coletadas em viveiro: análises histológicas de fígado, rins e brânquias.}

As imagens dos cortes histológicos dos tecidos fígado, rins e brânquias dos indivíduos do controle (injetados intraperitonealmente, com $1 \mathrm{ml}$ de soro fisiológico) são apresentadas nas (Figuras 16 a, b; 21 a, b; 26 a, b) com aspecto de animais saudáveis em ambas as espécies.

Apesar dos bioensaios realizados não terem apresentado resultados de mortandade, foi possível constatar alterações expressivas nos tecidos dos animais avaliados. O fígado dos peixes expostos as dosagens de 125, 250, 500 e 1.000 $\mathrm{mg} / \mathrm{kg}$ apresentou depósitos hepatocelulares intracitoplasmáticos com aparência de glicogênio/vacúolos ou lipídeo/vacúolos (Figuras 17 a, b; 18 a, b; 19 a, b; 20 a, b). Estes depósitos foram encontrados em todos os cortes histológicos das dosagens testadas e nas doses de 500 e 1.000 a intensidade da vacuolização (Figuras 19 a, b; $20 \mathrm{a}, \mathrm{b})$ foi maior que nas demais doses. Não foram encontradas outras alterações expressivas de nota, como necrose ou congestão. 
A (Figura 17 a, b) demonstra as alterações patológicas observadas durante os bioensaios que permitem melhor visualizar os resultados com relação à vacuolização citoplasmática. Na avaliação histopatológica do fígado verificou-se a vacuolização citoplasmática nos hepatócitos, porém não muito precisas, da quantidade de glicogênio ou de lipídeos nessas células.

Tendo em vista os resultados observados são necessários estudos mais específicos para elucidar se a alta vacuolização citoplástica no fígado dos peixes dessas espécies constitui uma alteração histológica (negativa) ou se é um evento comum que só deve ser considerado como uma alteração quando associado a algum tipo de degeneração, conforme sugerido por Takashima e Hibiya (1995).

A Tabela 19 e 20 apresenta a relação de alterações (IAH) ocorridas entre as espécies testadas com as amostras coletas com datas distintas. Foi possível verificar que ambas as espécies apresentaram níveis semelhantes de alterações para cada dose testada, exceto para as tilápias que receberam a dosagem de $1.000 \mathrm{mg} / \mathrm{kg}$ (Figura $20 \mathrm{a}, \mathrm{b}$ ). O mesmo padrão pode ser verificado nos resultados referentes às alterações histológicas com as amostras coletadas em períodos distintos. Embora estas amostras contivessem níveis diferentes detectados de toxinas, ambas apresentaram efeitos de alterações teciduais compatíveis entre si. Logo, a presença da toxina nas diferentes doses avaliadas demonstrou alterações histológicas expressivas e casos que indicasse o grau de resistência de cada uma das duas espécies em particular. Verificou-se que ambas as espécies sofreram impactos semelhantes da toxina. 
Tabela 19. Alterações histológicas consideradas na análise do fígado de matrinxã e tilápia nilótica exposto às amostras de coleta de água. O estágio considerado para cada alteração está indicado na segunda coluna. Baseado em método de Rigolin-Sá (1998), adotado por Meletti (2003), ajustado e adaptado no presente trabalho.

Alterações histológicas Estágio

\section{Alterações nos hepatócitos}

Desarranjos dos cordões hepáticos

Perda ou atipia do contorno celular

Perda ou atipia do contorno nuclear

Aumento do volume celular

Aumento do volume nuclear

Intensa vacuolização citoplasmática

II

Vacuolização nuclear

Tabela 20. Alterações histológicas no tecido hepático do matrinxã e tilápia nilótica dos exemplares analisados.

\begin{tabular}{lcccc}
\hline Doses (mg/kg) & \multicolumn{2}{c}{ Matrinxã } & \multicolumn{2}{c}{ Tilápia } \\
\hline & $\mathbf{2 7 / 0 5 / 0 7}$ & $\mathbf{1 9 / 0 8 / 0 7}$ & $\mathbf{2 7 / 0 5 / 0 7}$ & $\mathbf{1 9 / 0 8 / 0 7}$ \\
\hline Controle & 0 & 0 & 0 & 0 \\
125 & $\mathrm{I}$ & $\mathrm{I}$ & $\mathrm{I}$ & $\mathrm{I}$ \\
250 & $\mathrm{I}$ & $\mathrm{I}$ & $\mathrm{I}$ & $\mathrm{I}$ \\
500 & $\mathrm{I}$ & $\mathrm{I}$ & $\mathrm{I}$ & $\mathrm{I}$ \\
1.000 & $\mathrm{I}$ & $\mathrm{I}$ & $\mathrm{I}$ & $\mathrm{I}$ \\
\hline
\end{tabular}

Segundo Eler et al. (2006) exames histopatológicos no tecido hepático de Brycon cephalus com injeção de intraperitoneal de extrato algáceo liofilizado demonstraram que os peixes submetidos as dosagens de 250, 500 e $1.000 \mathrm{mg} / \mathrm{kg}$ apresentaram vacuolização do citoplasma, sendo verificadas necrose e congestão dos vasos no tecido analisado. 
As toxinas de cianobactérias, em especial hepatoxicinas do tipo microcistinaLR, têm sido descritas como causadoras das intoxicações e morte de peixes (Rabergh et al., 1991; Rodger et al., 1994; Phillips et al., 1995; Zimba et al., 2001).

Estudos realizados com trutas relatam que florações de cianobatérias podem ocasionar degenerações celulares, e necroses decorrentes de efeitos tóxicos pela consequência de alguns fatores (Rodger et al., 1994). Algumas espécies de cianobactérias tóxicas podem causar efeitos deletérios em peixes, elas são importantes componentes da dieta alimentar de determinadas espécies da família Cyclidae e Cyprinidae (Rabergh et al., 1991; Paerl e Tucker, 1995). Carmichael e Safferman (1992) destacam a tolerância de algumas espécies de carpas e tilápias às microcistinas, e podem indicar possível via de exposição do homem aos efeitos nocivos das cianotoxinas em caso de consumo (Carmichael, 1992).

Meletti (2003), em estudos feitos com Serrapinus notomelas e de Danio rerio expostos a amostras de sedimento de três bacias dos rios Piracicaba, Moji-Guaçu e Tibagi, relata que as análises histopatológicas do fígado demonstram vacuolização citoplasmática nos hepatócitos. Assim considerou apenas vacúolos muito grandes e numerosos, já que a presença de gordura não significa, por si só, algum estado patológico. Takashima e Hibiya (1995) alertam para o fato de que o termo degeneração por gorduras refere-se a uma condição patológica na qual há numerosas células com alto conteúdo de gordura, mas que apresentam, também, algum indício de degeneração, como a atrofia nuclear.

Meletti (2003) observou que em S. notomelas houve grande variação com relação à intensidade da vacuolização e ao número de organismos que apresentaram. No entanto, na maioria dos exemplares de $D$. rerio de cada tratamento foi observada alta vacuolização. A atrofia nuclear foi observada em $S$. notomelas e em $D$. rerio com maior frequência nos tratamentos com os sedimentos das localidades Sumaré, Americana e Piracicaba, na bacia do rio Piracicaba, sendo que nessa segunda espécie foi observada em todos os peixes do tratamento. Com relação aos estoques de glicogênio, estes diminuíram mais em $D$. rerio que em $S$. notomelas. Nos testes com $D$. rerio, pelo menos um peixe exposto em cada tratamento (com exceção do sedimento da localidade São João, na bacia do rio MojiGuaçu) teve redução dessas reservas. Foi preciso considerar que $D$. rerio possui menor massa corpórea, é mais ativo e, portanto deve ter metabolismo mais alto que a outra espécie. O autor acima citado ressalta que deve ser considerado, ainda, que 
os peixes permaneceram em jejum por 120 horas (24 horas antecedentes aos testes mais o período de duração dos testes). No entanto, é interessante notar que nos testes com S. notomelas, tratamentos como Limeira e Piracicaba tiveram um maior número de peixes com reservas de glicogênio diminuídas. Com relação os testes com amostras de sedimento da bacia do rio Piracicaba, com D. rerio, na maioria dos peixes de cada tratamento foi observada a redução de glicogênio, inclusive no local referência.
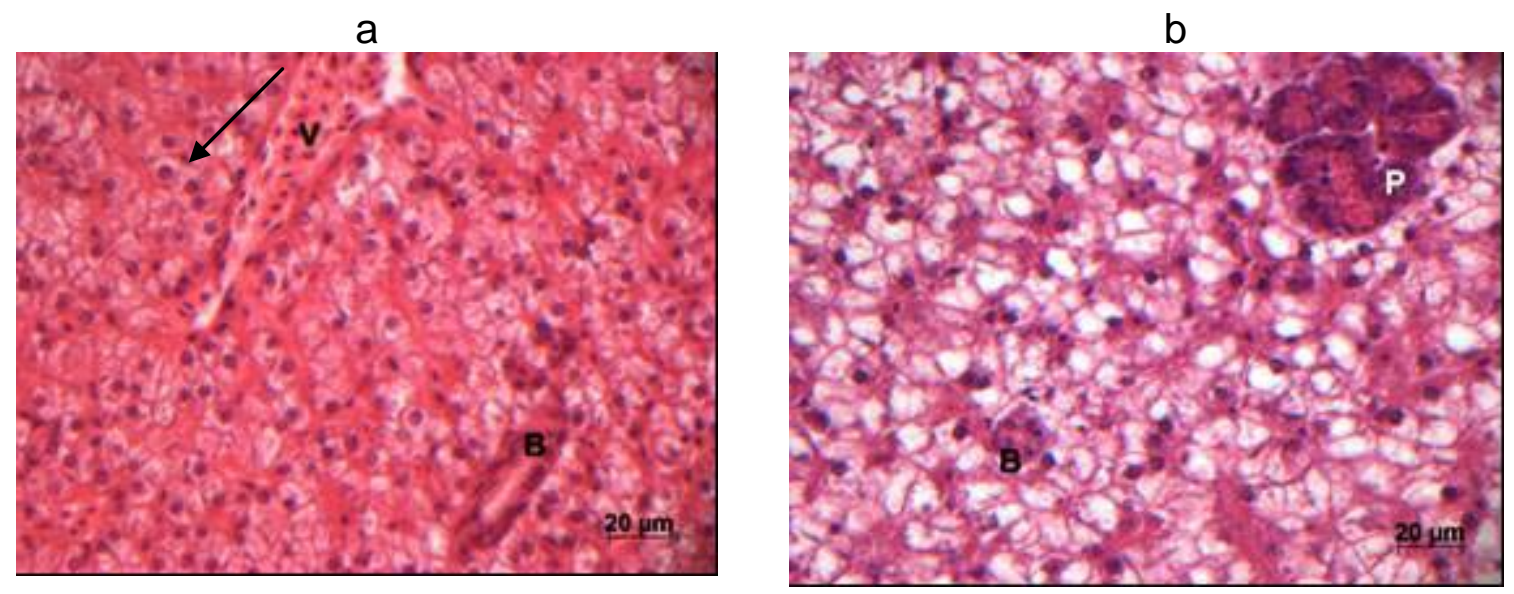

Figura 16. Corte histológico do tecido hepático do matrinxã (Brycon cephalus) (a) e tilápia nilótica (Oreochromis niloticus) (b) - controle injetados com $1 \mathrm{ml}$ de soro fisiologico. Observar o arranjo do ducto biliar (B), veia central $(V)$ e o pâncreas $(P)$. Notar seta $(\rightarrow)$ o formato dos hepatócitos e seus núcleos grandes e arredondados. Escala: (40-1300x1030S) (HE, $6 \mu \mathrm{m})$. 
a

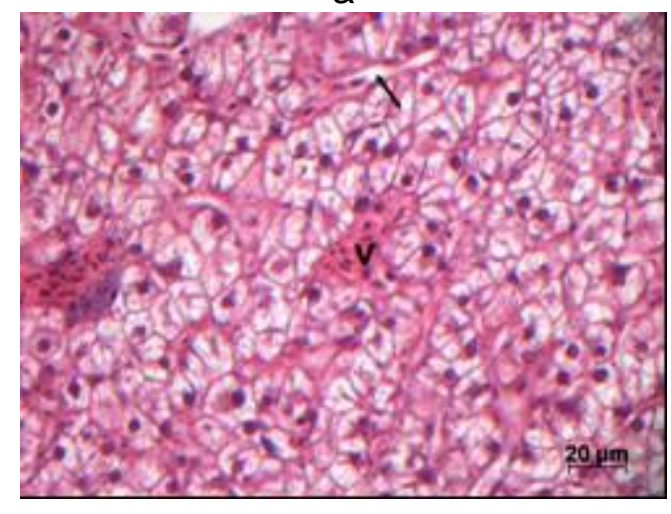

b

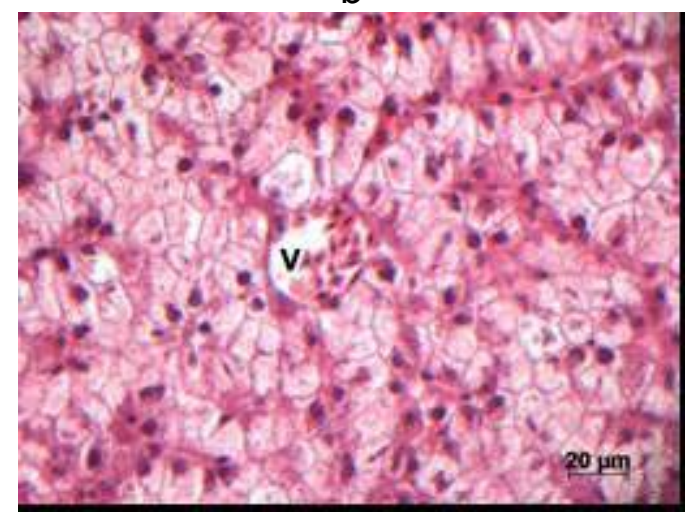

Figura 17. Corte histológico do tecido hepático do matrinxã (Brycon cephalus) (a) e tilápia nilótica (Oreochromis niloticus) (b) - dose 125 mg/kg. Notar a veia central $(V)$, seta $(\rightarrow)$ sinusóide hepático e a presença de pequena vacuolização. Escala: (40-1300x1030S) (HE, $6 \mu \mathrm{m})$.

a

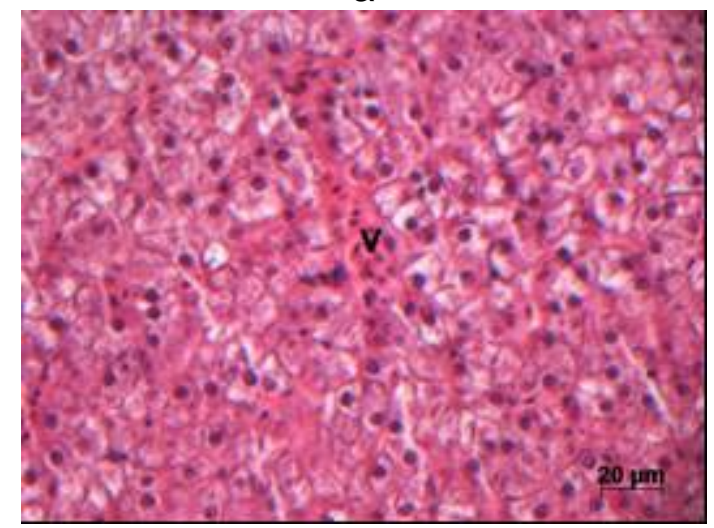

b

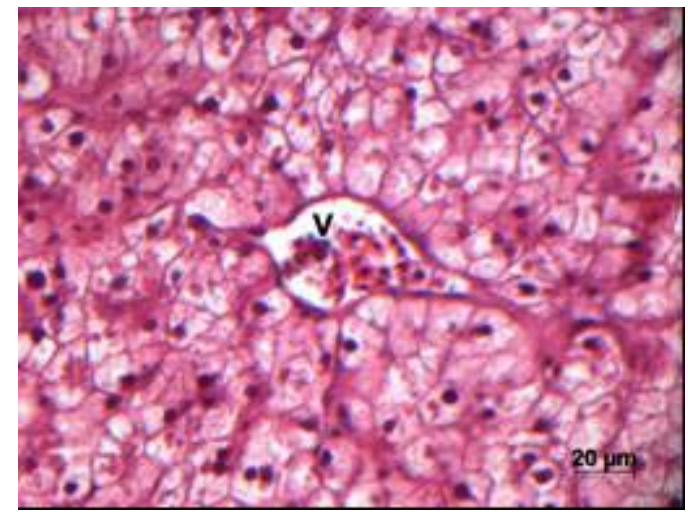

Figura 18. Corte histológico do tecido hepático do matrinxã (Brycon cephalus) (a) e tilápia nilótica (Oreochromis niloticus) (b) - tratamento da dose $250 \mathrm{mg} / \mathrm{kg}$. Notar a veia central (V), e a presença de pequena vacuolização. Escala: (401300x1030S) (HE, $6 \mu \mathrm{m})$. 
a

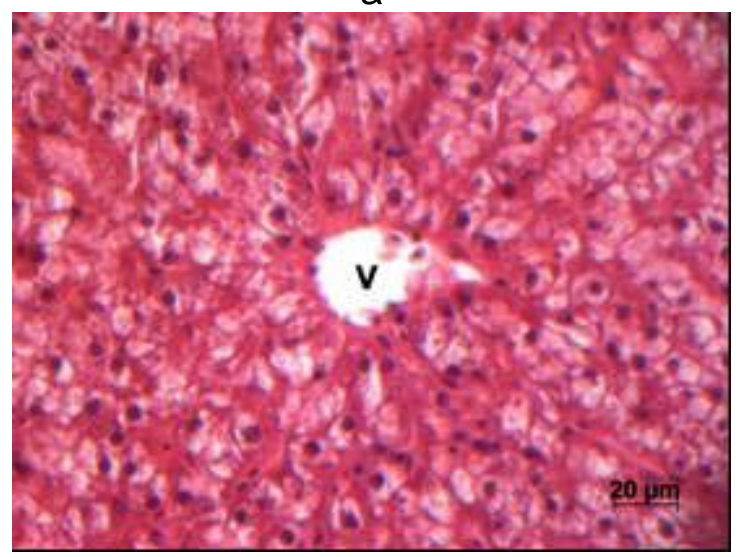

b

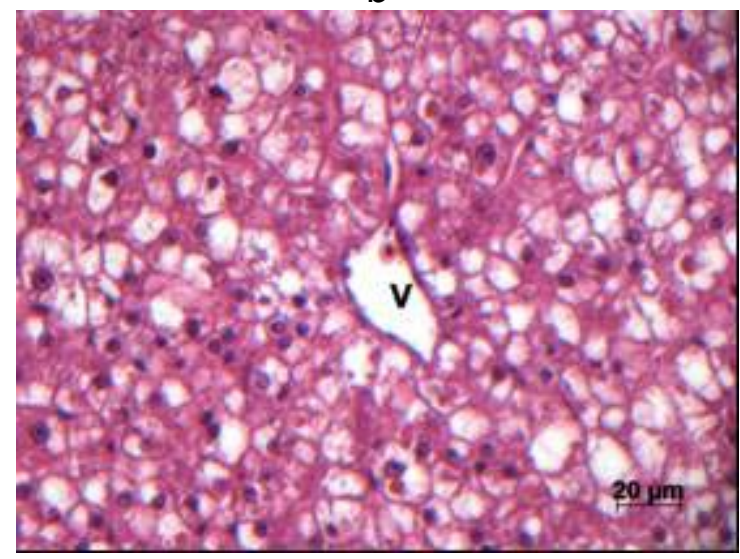

Figura 19. Corte histológico do tecido hepático de matrinxã (Brycon cephalus) (a) e tilápia nilótica (Oreochromis niloticus) (b) - tratamento da dose $500 \mathrm{mg} / \mathrm{kg}$. Notar a veia central (V) e a presença de vacuolização. Escala: (40-1300x1030S) (HE, $6 \mu \mathrm{m})$.

a

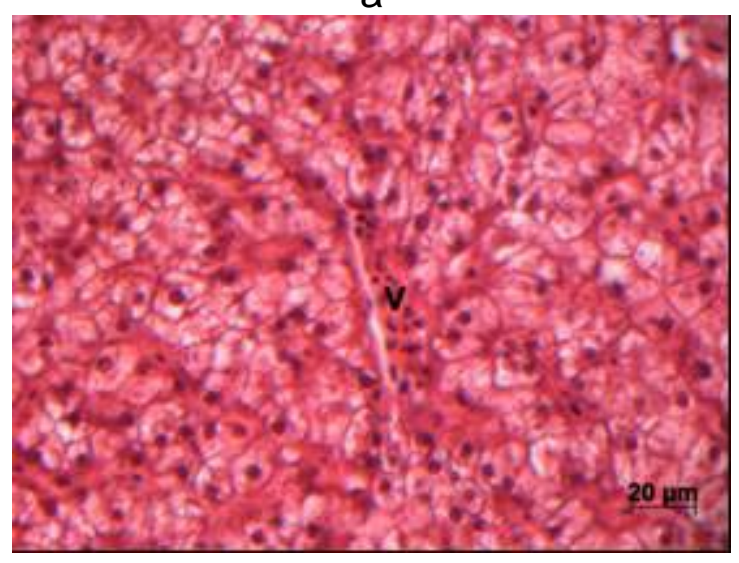

b

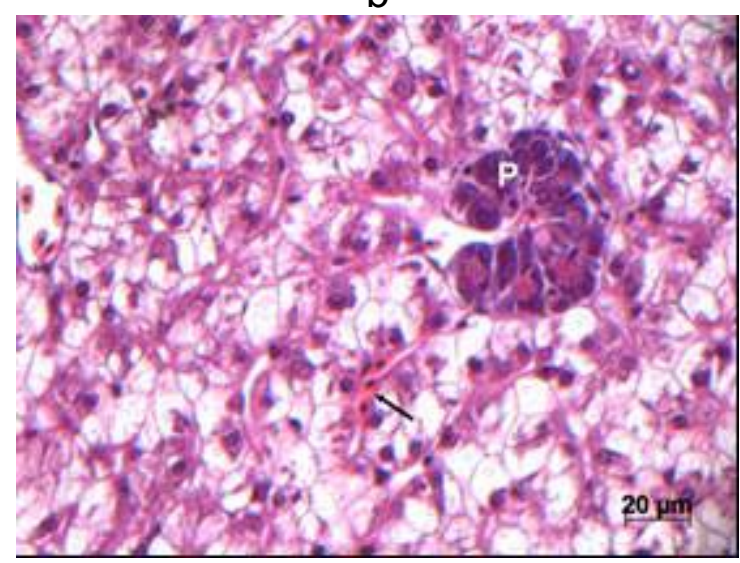

Figura 20. Corte histológico do tecido hepático de matrinxã (Brycon cephalus) (a) e tilápia nilótica (Oreochromis niloticus.) (b) - dose 1.000 mg/kg, notar a veia central $(V)$, seta $\rightarrow$ ) sinusóide hepático e o pâncreas (tecido pancreático hepatopâncreas) (P) presença de intensa vacuolização de glicogênio. Escala: (40-1300x1030S) (HE, $6 \mu \mathrm{m})$. 
As Tabelas 21 e 22 apresentam os índices de alterações histológicas (IAH) dos dados brutos das alterações patológicas, nocivas das espécies estudadas. $O$ estudo histológico realizado no presente trabalho demonstra discreta degeneração vacuolar observada em função do epitélio tubular renal. Há tendência de intensificação desta degeneração conforme aumento a dose. Nas doses de 125 a $500 \mathrm{mg} / \mathrm{kg}$ com as matrinxãs (Figuras 22 a, 23 a, 24 a), nas duas coletas de água, foram verificadas alterações brandas, e na dose de $1.000 \mathrm{mg} / \mathrm{kg}$ foram observadas alterações de brandas a moderadas (Figura 25 a). Na tilápia, nas doses de 125 a $500 \mathrm{mg} / \mathrm{kg}$ das duas coletas de água, não foi possível observar alterações mais severas (Figuras 22 b, 23 b, 24 b), enquanto que na dose de 1.000 mg/kg os animais das duas coletas de água apresentaram alteração branda a moderada (Figuras 25 b).

Tabela 21. Alterações histológicas consideradas nas análises do tecido renal de matrinxã e tilápia nilótica exposto as amostra de coleta de água. O estágio considerado para cada alteração está indicado na segunda coluna.

\begin{tabular}{lc}
\hline \multicolumn{1}{c}{ Alterações histológicas } & Estágio \\
\hline Alterações nos glomérulos e túbulos renais & II \\
Degeneração tubular & II \\
Degeneração citoplasmática das células tubulares & II \\
Degeneração nuclear das células tubulares & \\
\hline
\end{tabular}


Tabela 22. Alterações no tecido renal do matrinxã e tilápia nilótica das duas coletas de água.

\begin{tabular}{lcccc}
\hline Doses (mg/kg) & \multicolumn{2}{c}{ Matrinxã } & \multicolumn{2}{c}{ Tilápia } \\
\hline & $\mathbf{2 7 / 0 5 / 0 7}$ & $\mathbf{1 9 / 0 8 / 0 7}$ & $\mathbf{2 7 / 0 5 / 0 7}$ & $\mathbf{1 9 / 0 8 / 0 7}$ \\
\hline Controle & 0 & 0 & 0 & 0 \\
125 & $\mathrm{II}$ & $\mathrm{II}$ & $\mathrm{I}$ & $\|$ \\
250 & $\mathrm{I}$ & $\mathrm{I}$ & $\|$ & $\|$ \\
500 & $\mathrm{I}$ & $\mathrm{I}$ & $\|$ & $\|$ \\
1.000 & $\mathrm{I}$ & $\mathrm{I}$ & $\mathrm{I}$ & $\|$ \\
\hline
\end{tabular}

As alterações dos glomérulos foram mais evidentes para o matrinxã nas dosagens de 125, 250, 500 e $1.000 \mathrm{mg} / \mathrm{kg}$ com o extrato bruto de fitoplâncton (Figuras 22 a; 23 a; 24 a; 25 a) liofilizada das duas coletas. No entanto as tilápias apresentaram discreta degeneração somente na dose de 1.000 (Figura 25 b). Não foram encontradas áreas de necrose. Os resultados deste estudo foram semelhantes aos encontrados por Kotak et al. (1996) em observações histológicas no tecido renal de truta arco-iris (Onchorhynchus myskiss).

Estudos feitos por Eler et al. (2006) com Brycon cephalus expostos à floração de algas, demonstra que alterações histopatológicas degenerativas nos tecidos renais foram observadas em todos os indivíduos testados com os extratos algáceos liofilizados, inclusive nos sobreviventes. Entretanto, as alterações severas foram encontradas nos indivíduos mortos durante o bioensaio e no tratamento $125 \mathrm{mg} / \mathrm{kg}$, em que se observaram alterações caracterizadas pela vacuolização das células do epitélio, com desorganização dos glomérulos e desintegração tubular seguida de nefrose.

Molina et al. (2005) relatam que, como as células de cianobactérias tóxicas liofilizadas administradas na ração via oral afetam os parâmetros enzimáticos, tais como a fosfatase ácida (ACP), fosfatase alcalina (ALP) e alterações morfológicas em fígado, rins, brânquias e mucosa intestinal (somente histopatologia) de tilápia nilótica (Oreochromis sp.), evidenciaram lesões dos rins que foram constituídas da dilatação do espaço de Bowman e células epiteliais necróticas com túbulos de núcleos de picnóticos. 
Meletti (2003), em estudos feitos com Serrapinus notomelas e de Danio rerio expostos às amostras de sedimento de três bacias dos rios Piracicaba, Moji-Guaçu e Tibagi, com testes de toxicidade de sedimentos in situ e em laboratório observou alterações renais que ocorrem em maior frequência e intensidade nestes dois peixes expostos aos sedimentos contaminados. As analises histológicas evidenciaram alterações tubulares, do tipo "cloudy swelling" no rim, caracterizada por células epiteliais tubulares inchadas ou hipertrofiadas, com grânulos finos eosinófilos no citoplasma (hipertrofia das células tubulares) e degeneração por glóbulos hialinos, caracterizada pela presença de grandes grânulos eosinófilos no citoplasma. Segundo Takashima e Hibiya (1995) podem ser produzidos dentro da própria célula ou formados pela reabsorção do excesso de substâncias protéicas eventualmente filtradas no glomérulo.
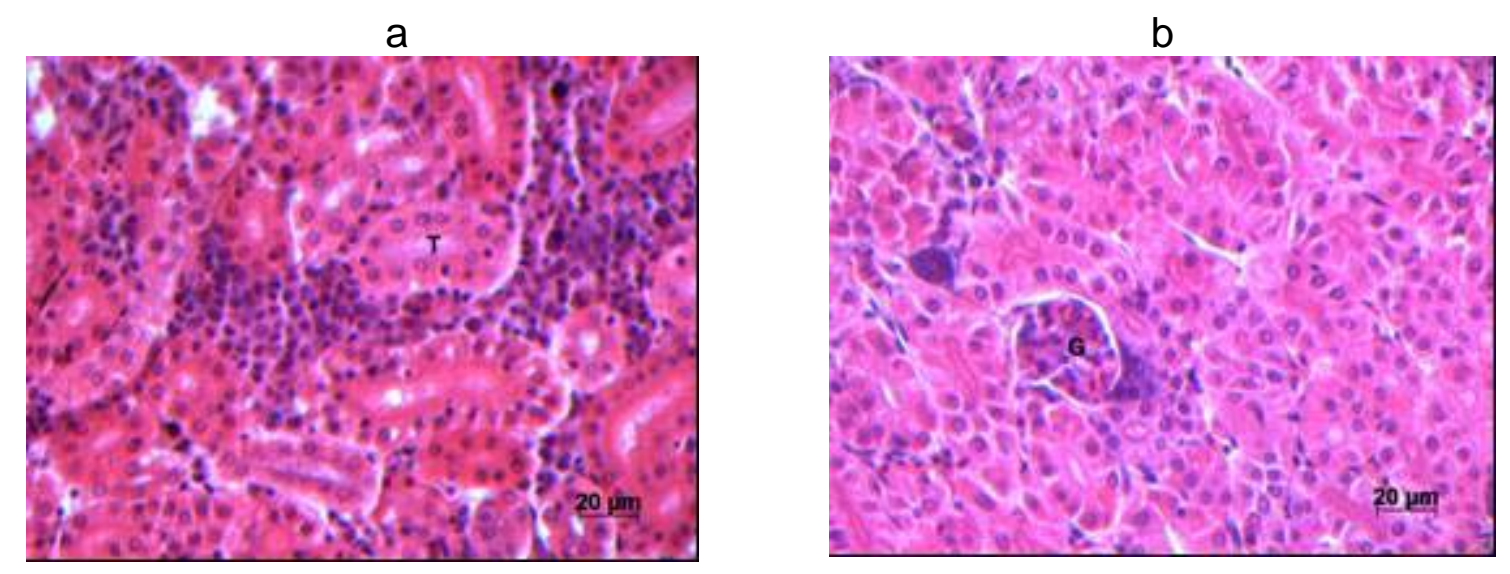

Figura 21. Corte histológico do tecido renal do controle de exemplares de matrinxã (Brycon cephalus) (a) e tilápia nilótica (Oreochromis niloticus) (b) submetidos a bioensaio injetados com $1 \mathrm{ml}$ de soro fisiologico. Notar que os glomérulos (G) e Túbulo (T) estão com aparência de normal. Escala: (401300x1030S) (HE, $6 \mu \mathrm{m})$. 
a

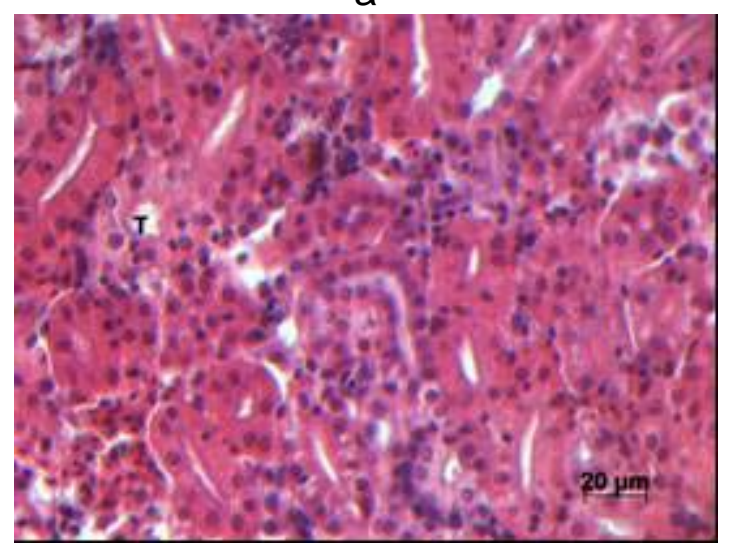

b

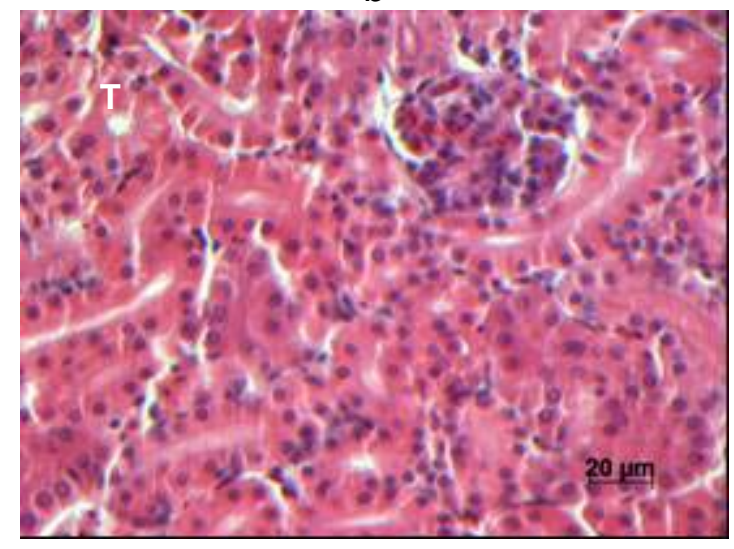

Figura 22. Corte histológico do tecido renal de matrinxã (Brycon cephalus) (a) e tilápia nilótica (Oreochromis niloticus) (b) - tratamento da dose $125 \mathrm{mg} / \mathrm{kg}$. Notar a presença de túbulos (T) com pequena deformação. Escala: (40-1300x1030S) (HE, $6 \mu \mathrm{m})$.

a

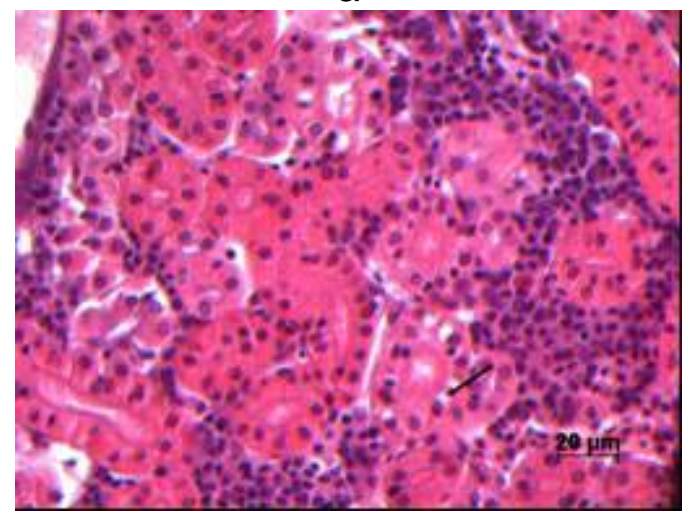

b

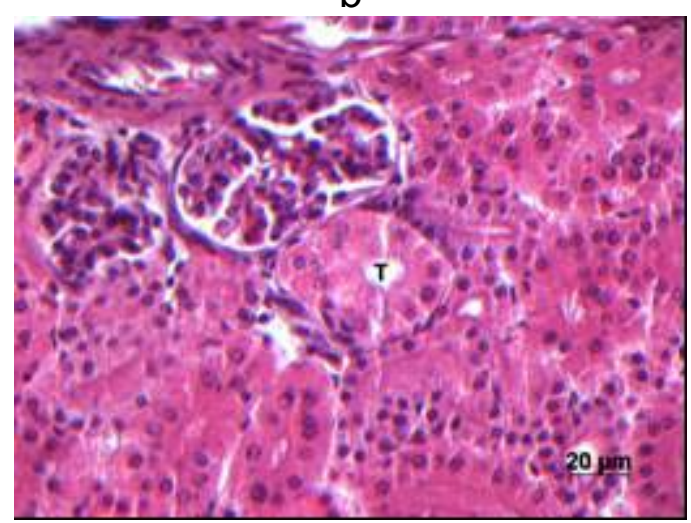

Figura 23. Corte histológico do tecido renal de matrinxã (Brycon cephalus) (a) e tilápia nilótica (Oreochromis niloticus) (b) - tratamento da dose $250 \mathrm{mg} / \mathrm{kg}$. Notar a presença de túbulos $(T)$ e as setas $(\rightarrow)$ apresentando vacuolização nas células epiteliais. Escala: (40-1300×1030S) (HE, $6 \mu \mathrm{m})$. 

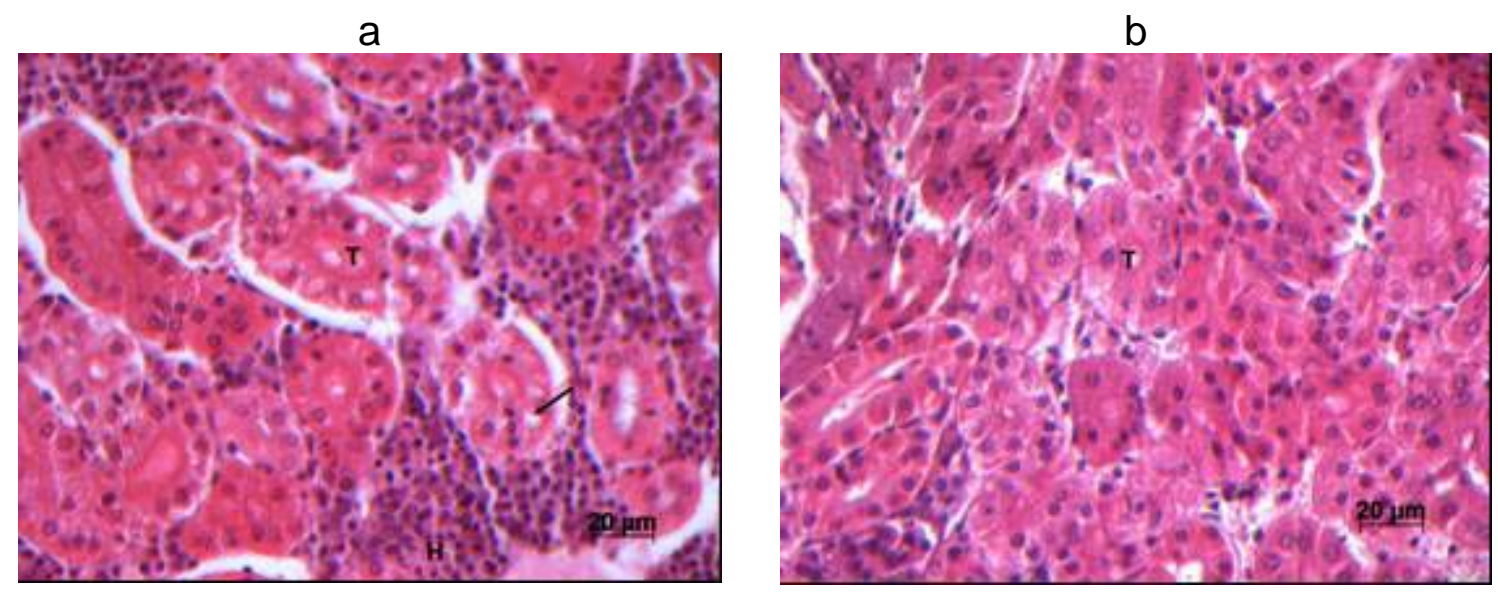

Figura 24. Corte histológico do tecido renal de matrinxã (Brycon cephalus) (a) e tilápia nilótica (Oreochromis niloticus) (b) - tratamento da dose 500 mg/kg. Notar a presença de túbulos $(T)$ e as seła\$ łpresentando vacuolização das células epiteliais mais evidenciadas no matrinxã. Escala: (40-1300x1030S) (HE, $6 \mu \mathrm{m})$.

a

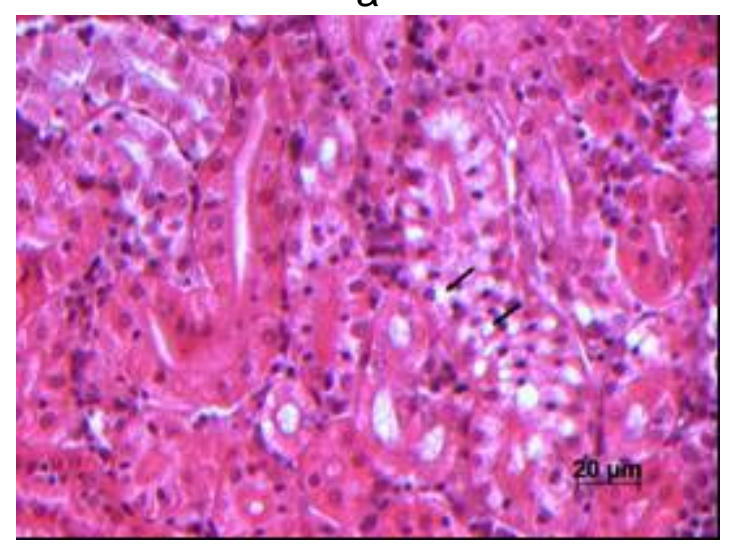

b

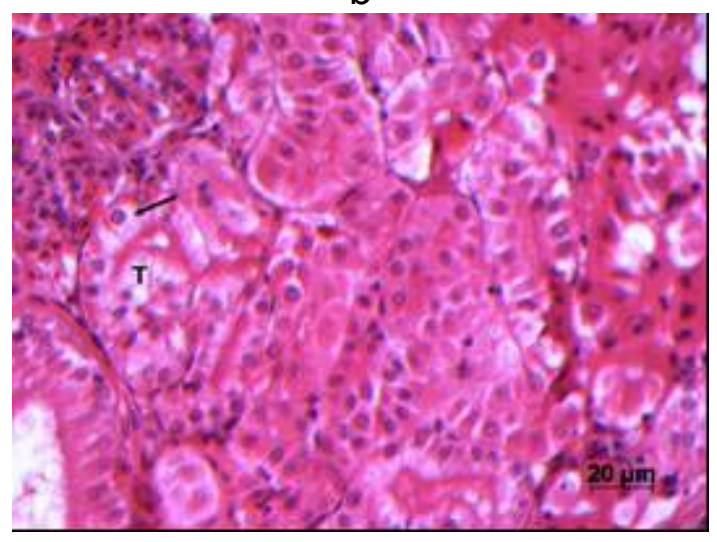

Figura 25. Corte histológico do tecido renal de matrinxã (Brycon cephalus) (a) e tilápia nilótica (Oreochromis niloticus) (b) - tratamento da dose $1.000 \mathrm{mg} / \mathrm{kg}$. Notar a presença de túbulos $(\mathrm{T})$ e as setas $(\rightarrow)$ a presentando vacuolização em células epiteliais (degeneração vacuolar) nas duas espécies. Escala: (401300x1030S) (HE, $6 \mu \mathrm{m})$. 
No estudo histológico dos tecidos branquiais realizados desde a dose de 125 até $1.000 \mathrm{mg} / \mathrm{kg}$ ocorreu proliferação de epitélio de revestimento (hiperplasia) das brânquias, com intensidade maior conforme foi aumentada a dose da toxina (Figuras 27 a, b, 28 a, b, 29 a, b, 30 a, b) nas duas espécies. Observa-se fusão total das lamelas secundárias estágio de $2^{\circ}$ grau, principalmente a partir da dose de 500 mg/kg, tanto para matrinxã como para as tilápias. (Figuras 29 a, b, 30 a, b).

Foi constatado o efeito de alterações (IAH) nos tecidos branquiais (Tabela 23 e 24) em todos os indivíduos testados com os extratos algáceos. Pode-se observar que, na dose de $1.000 \mathrm{mg} / \mathrm{kg}$ tanto para matrinxã como a tilápia nas duas coletas houve a fusão total das lamelas secundarias (Figura 30 a, b), sendo que, para as tilápias essa fusão total de todas as lamelas foi mais acentuada.

Verificou-se, também, que ambas as espécies apresentaram níveis semelhantes de alterações para cada dose testada, exceto nas tilápias submetidas à dosagem de 1.000 mg/kg (Figura 30 b). O mesmo padrão pode ser verificado nos resultados referentes às alterações histológicas (Tabela 24) com as amostras coletadas em períodos distintos. Embora estas amostras tivessem níveis diferentes detectados de toxinas, ambas apresentaram efeitos de alterações teciduais compatíveis entre si.

Tabela 23. Alterações histológicas na análise das brânquias de matrinxã e tilápia nilótica exposto às amostras de coleta de água. O estágio considerado para cada alteração está indicado na segunda coluna.

\section{Alterações histológicas} Estágio

\section{Hipertrofia e hiperplasia do tecido respiratório}

Hiperplasia das células epiteliais na base das lamelas secundarias

Hiperplasia das células epiteliais ao longo das lamelas secundarias

Fusão parcial (na base ou no topo) das lamelas secundárias

Fusão completa de algumas lamelas secundárias

Fusão completa de todas as lamelas secundarias 
Tabela 24. Alterações histológicas do tecido Branquial do matrinxã e tilápia nilótica das duas coletas de água.

\begin{tabular}{lcccc}
\hline Doses (mg/kg) & \multicolumn{2}{c}{ Matrinxã } & \multicolumn{2}{c}{ Tilápia } \\
\hline & $\mathbf{2 7 / 0 5 / 0 7}$ & $\mathbf{1 9 / 0 8 / 0 7}$ & $\mathbf{2 7 / 0 5 / 0 7}$ & $\mathbf{1 9 / 0 8 / 0 7}$ \\
\hline Controle & 0 & 0 & 0 & 0 \\
125 & II & II & II & II \\
250 & II & II & II & II \\
500 & II & II & II & II \\
1.000 & II & II & III & III \\
\hline
\end{tabular}
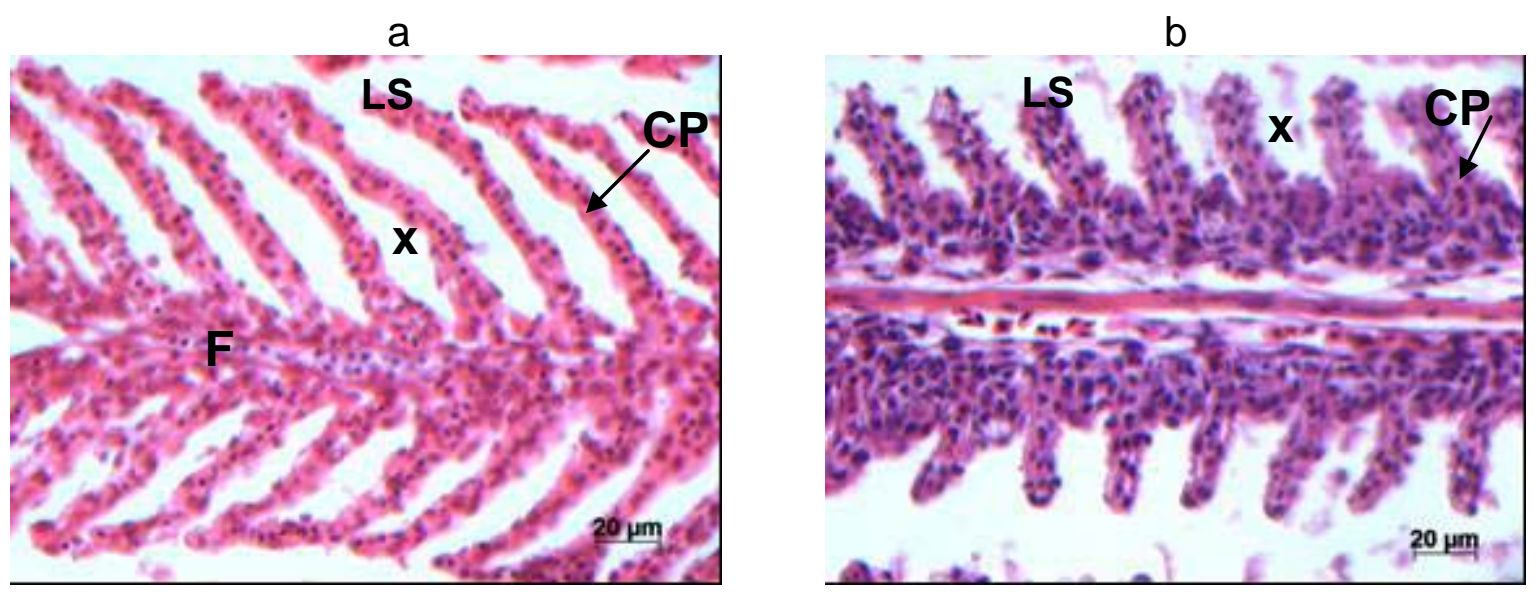

Figura 26. Corte histológico do tecido branquial de matrinxã (Brycon cephalus) (a) e tilápia nilótica (Oreochromis niloticus) (b) - do controle injetados com $1 \mathrm{ml}$ de soro fisiológico. Observar os espaços interlamelares bem definidos (x); lamelas secundarias desenvolvidas (LS); filamento primário (F); seta células pilares (CP). Escala: (40-1300x1030S) (HE, $6 \mu \mathrm{m})$. 
a

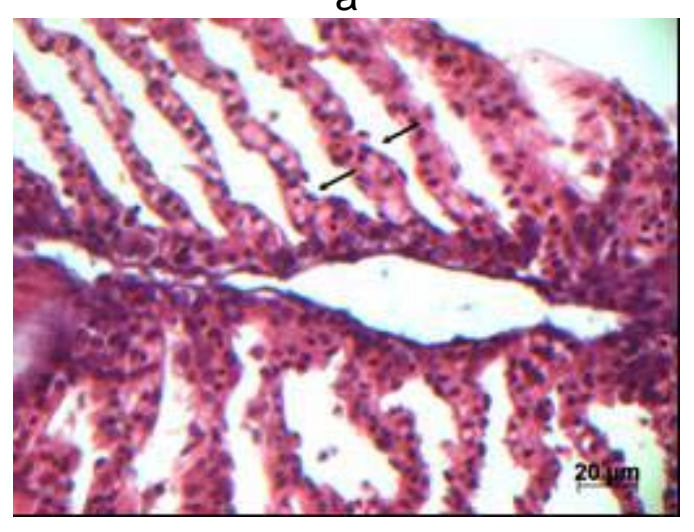

b

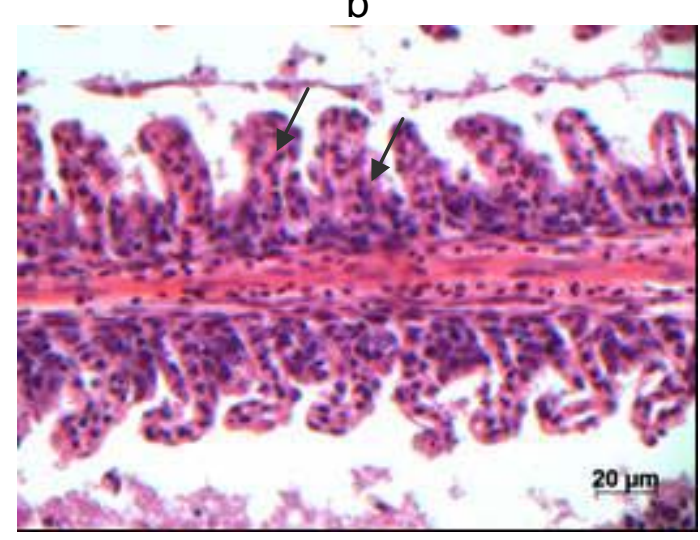

Figura 27 Corte histológico do tecido branquial de matrinxã (Brycon cephalus) (a) e tilápia nilótica (Oreochromis niloticus) (b) - tratamento da dose de 125 $\mathrm{mg} / \mathrm{kg}$. Observar os espaços das lamelas secundarias as setas $(\rightarrow)$. Notar a desorganização das lamelas secundaria e a pequena congestão vascular. Escala: (40-1300x1030S) (HE, $6 \mu \mathrm{m})$.

a

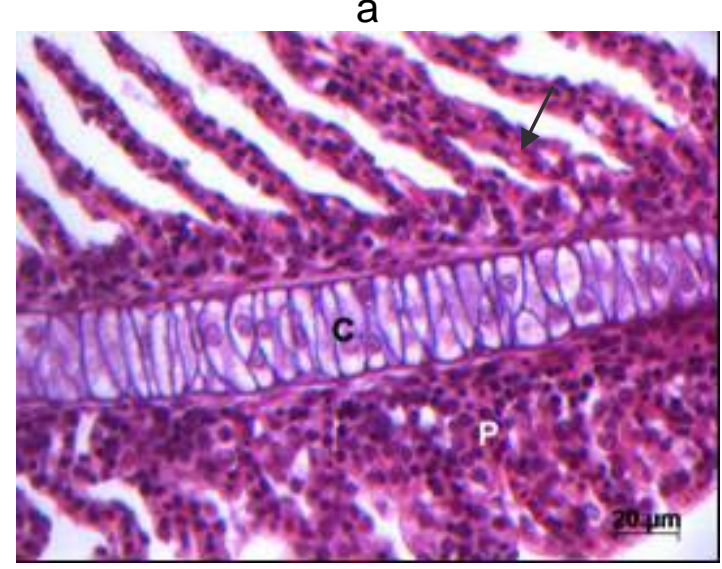

b

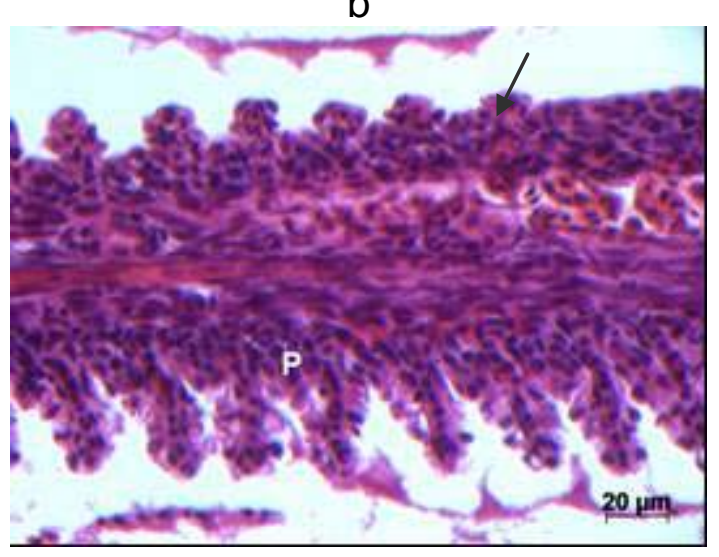

Figura 28. Corte histológico do tecido branquial de matrinxã (Brycon cephalus) (a) e tilápia nilótica (Oreochromis niloticus) (b) - tratamento da dose de 250 $\mathrm{mg} / \mathrm{kg}$. Observar a cartilagem (C), proliferação epitelial $(P)$. Notar na seta presença de proliferação epitelial das lamelas secundarias. Escala: (401300x1030S) (HE, $6 \mu \mathrm{m})$. 

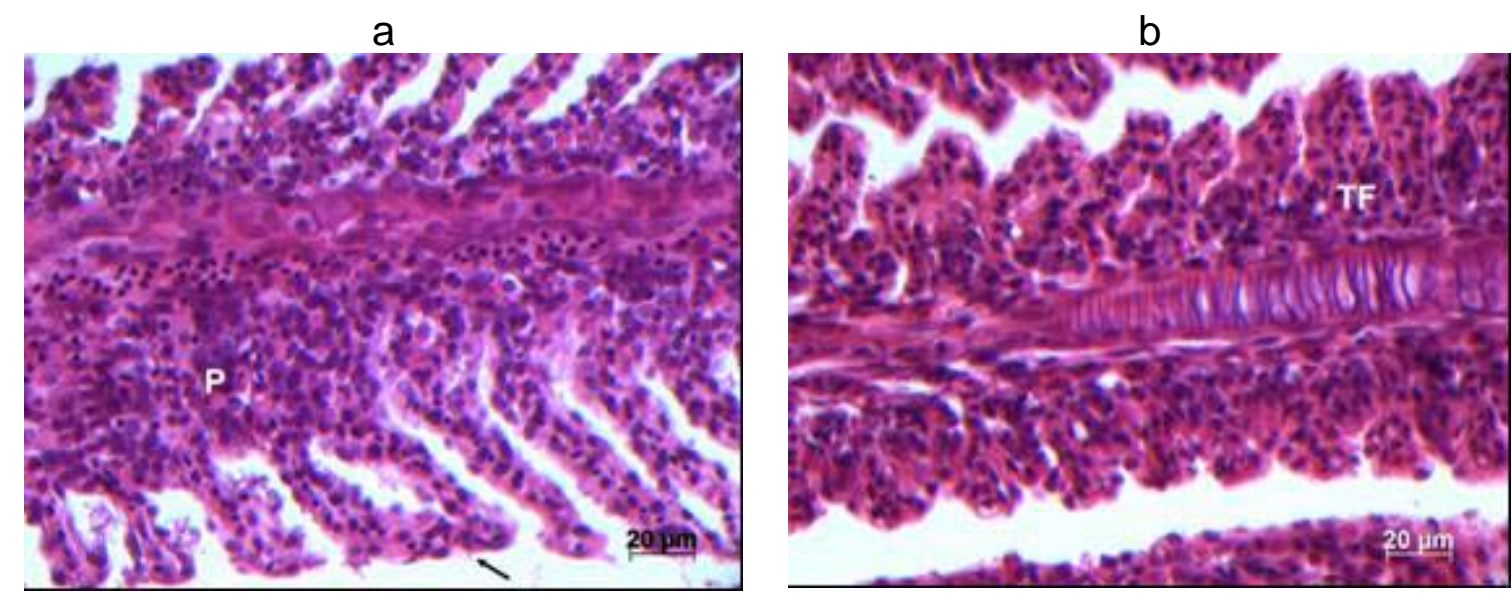

Figura 29. Corte histológico do tecido branquial de matrinxã (Brycon cephalus) (a) e tilápia nilótica (Oreochromis niloticus) (b) - tratamento da dose de 500 $\mathrm{mg} / \mathrm{kg}$. Observar o a proliferação epitelial $(P)$ e a seta)(fusão lamelar na matrinxã. Notar a presença de fusão total de lamelas (TF) na tilápia. Escala: (401300x1030S) (HE, $6 \mu \mathrm{m})$.
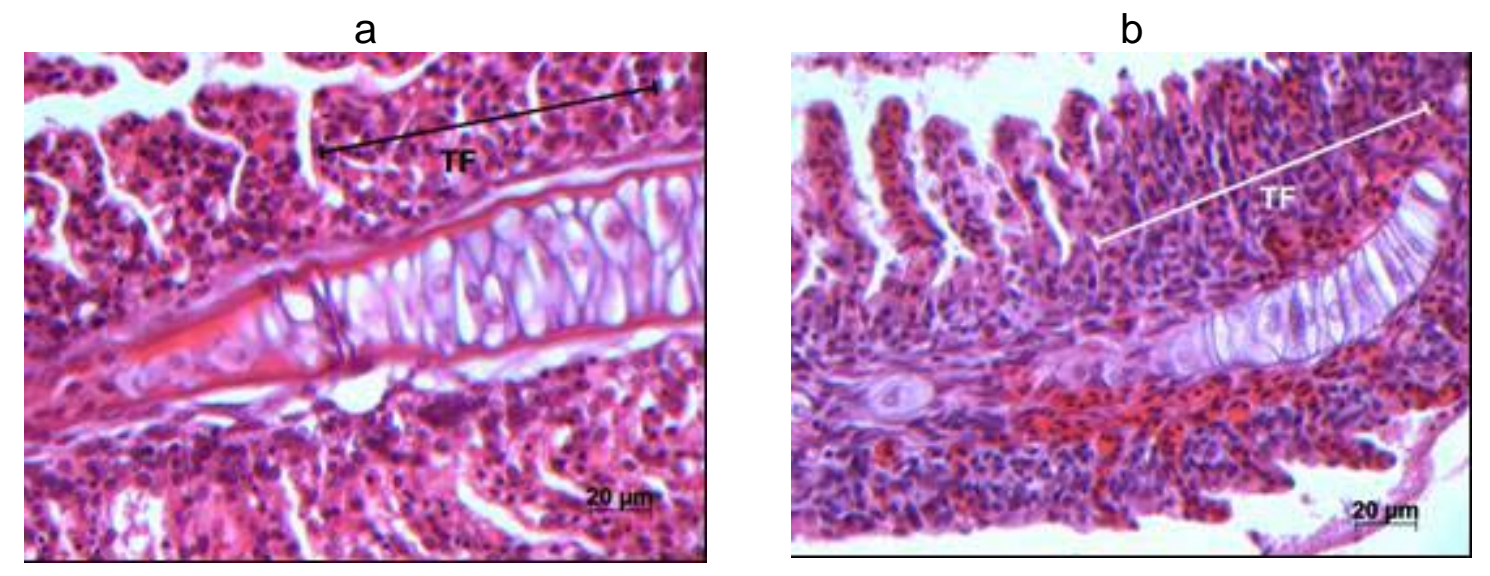

Figura 30. Corte histológico do tecido branquial de matrinxã (Brycon cephalus) (a) e tilápia nilótica (Oreochromis niloticus) (b) - tratamento da dose de 1.000 $\mathrm{mg} / \mathrm{kg}$. Observar fusão total de lamelas (TF) nas setas $(\leftrightarrow)$. Notar a presença de fusão total de lamelas secundárias nas duas especies. Escala: (40-1300x1030S) $(\mathrm{HE}, 6 \mu \mathrm{m})$. 
Foram observadas alterações caracterizadas pelas injúrias branquiais decorrentes do efeito tóxico em estudos realizados com trutas (Salmo trutta L.) e indicaram que florações de cianobactérias podem ocasionar degenerações celulares, necroses e irritação branquial decorrentes de efeitos tóxicos ou físicos ou da combinação desses fatores (Rodger et al., 1994). Embora algumas espécies de cianobactérias tóxicas possam causar efeitos deletérios a peixes quando ingeridas, elas são importantes componentes da dieta alimentar de determinadas espécies da famílias Cichlidae e Cyprinidae (Rabergh et al., 1991; Paerl e Tucker, 1995). Estudos realizados por Carmichael e Safferman (1992) destacam a tolerância de algumas espécies de carpa e tilápia às microcistinas, o que pode indicar possível via de exposição do homem aos efeitos nocivos das cianotoxinas em caso de seu consumo.

Eler et al. (2009) coletaram um florescimento de algas em pesque-pague da bacia do rio Moji-Guaçu e testaram esses extratos algáceos em diferentes concentrações. Também injetaram esses extratos intraperitonealmente em Brycon cephalus, constatando evidências histológicas de proliferação entre as células das lamelas secundárias, tendo sido mais evidente nas concentrações de 250 e 500 $\mathrm{mg} / \mathrm{kg}$. Assim, concluíram que a fusão das lamelas secundárias ocorre em todas as dosagens testadas desde a dose 125 até $1.000 \mathrm{mg} / \mathrm{kg}$.

Takashima e Hibiya (1995) relatam que em primeiro lugar as mudanças degenerativas vacuolares e necrose são observadas nas lamelas epiteliais das brânquias da carpa. Quando as lamelas secundárias são danificadas por parasitos e ou agentes irritantes químicos e físicos, as mudanças patológicas desse tipo ocorrem em curtos períodos. As células epiteliais danificadas eventualmente esfoliam, o que frequentemente vem acompanhado por hemorragia dos capilares sanguíneos. Consequentemente a hemorragia ocorre nas áreas danificadas e continua por um período longo resultando em condições anêmicas. Esta condição indica congestão e pode ser causada pela não fragmentação de grande quantidade de sangue fluindo da artéria branquial eferente ou pela insuficiência de fluxo na artéria branquial eferente. A degeneração progressiva das lamelas em formato de maçã é um exemplo de degeneração progressiva nas brânquias. As células interlamelares se proliferam em excesso preenchendo os espaço dentro das lamelas secundárias. Portanto na preparação histológica o autor observou que a lamela secundária tem o formato de maçã. 


\section{CONCLUSÕES}

- A avaliação da qualidade de água no viveiro estudado mostrou tendência para um ambiente hipereutrófico.

- Foi verificada a presença e dominância de cianobactéria nas amostras.

- As espécies de cianobactérias encontradas nas duas amostras de água coletadas nesse empreendimento apresentaram efeito nocivo para as duas espécies de peixes no teste ecotoxicolgico.

- Foram encontradas microcistina nas amostras de florescimentos no viveiro amostrado.

- Os extratos da cultura de Microcystis aeruginosa foram tóxicos com efeitos nos tecidos dos peixes avaliados.

- Os extratos brutos de florações do viveiro, em concentrações acima de 125 $\mathrm{mg} / \mathrm{kg}$ de peso corporal, injetados em peixes provocaram efeitos deletérios com expressiva alteração nas brânquias, rins e fígado.

- Foram constatados padrões de injurias nos tecidos avaliados dos peixes testados mediante exposição à cianotoxinas.

- Os tecidos branquiais foram aqueles que apresentaram grau máximo de alteração histológica.

- Matrinxã se mostrou mais sensível à cepa de Microcytis aeruginosa.

- Uso de matrinxã pode representar um organismo bioindicador para efeitos tóxicos associados a cianobactérias. 


\section{CONSIDERAÇÕES FINAIS}

A qualidade da água é um fator limitante para o desenvolvimento social e econômico do País. Algumas lacunas precisam ser preenchidas para que possa garantir, de forma confiável, a qualidade de água em nossos mananciais.

Uma das principais lacunas sobre as informações disponíveis sobre os diferentes aspectos envolvidos com as causas e consequências da ocorrência de florescimento de cianobactéria em tanques de piscicultura, assim como nos mananciais de abastecimento.

Entretanto fica clara a necessidade de melhoria de manejo de viveiros e alimentação oferecida aos animais nos sistemas de criação de peixes, evitando assim as florações de cianobactérias tóxicas nestes empreendimentos.

Avaliar características da área de entorno para implantação de empreendimento piscícola.

O manejo adequado ao sistema adotado e controle da qualidade da água no empreendimento piscícola é de extrema importância para o piscicultor.

Recomenda-se como ferramenta, a implantação das análises da qualidade da água de empreendimentos piscícolas segundo resolução do Conselho Nacional do Meio Ambiente - CONAMA 357, de 17 de março de 2005 e Portaria FUNASA (2001), pelo menos duas vezes ao ano (seca e chuva). O objetivo dessa aplicação Legal, como fiscalização pelos órgãos públicos, é a garantia da integridade do pescado e da segurança alimentar do consumidor. 


\section{REFERÊNCIAS BIBLIOGRÁFICAS}

APELDOORN, M. E.; EGMOND, H. P.; SPEIJERS, G. J. A.; BAKKER, G. J. I. Toxins of cyanobacteria. Molecular. Molecular Nutrition \& Food Research, v. 51, p.7-60, 2007.

AZEVEDO, S. M. F. O.; VASCONCELOS, V. M. Toxinas de cianobactérias: causas e conseqüência para a saúde pública. In: ZAGATTO, P.A.; BERTOLETTI, E.

Ecotoxicologia Aquática - Princípios e Aplicações. São Carlos: RiMA, p. 433-452, 2006.

BICUDO, C. E. M.; BICUDO, R. M. T. Algas de águas continentais brasileiras: chave ilustrada para identificação de gêneros. São Paulo: Fundação Brasileira para o Desenvolvimento de Ciências, 1970. 228 p.

BITTENCOURT-OLIVEIRA, M. do C.; OLIVEIRA, M. C. de; YUNES, J. S. Cianobactérias tóxicas. Revista Biotecnologia, v. IV, n. 23, p. 44-47, 2001.

BOURRELLY, P. Les algues d'au douce: initiation a la sistématique. SaintMichel: Société Nouvelle des Editions Boubée, 1981. t. I, II e III.

BOYD, C. E. Water quality in Warmwater fish Culture. Auburn University, 1981. $359 \mathrm{p}$.

BOYD, C. E.; QUEIROZ, J. Aquaculture pond effluent management. Aquaculture Asia, p. 43-46, April-June 1997.

BUYNDER, P. G. Van; OUGHTRED, T.; KIRKBY, B.; PHILLIPS, S.; EAGLESHAM, G.; THOMAS, K.; BURCH, M. Nodularin uptake by seafood during a cyanobacterial bloom. M. Environmental Toxicology, v. 16, n. 6, p. 468-471, 2001.

CARBIS, C. R.; RAWLIN, G. T.; GRANT, P.; MITCHELL, G. F.; ANDERSON, J. W.; McCAULEY, I. A study of feral carp, Cyprinus carpio L., exposed to Microcytis aeruginosa at Lake Mokoan, Australia, and possible implications for fish heath. Journal of Fish Diseases, v. 20, p. 81-91, 1997.

CARMICHAEL, W. W.; SAFFERMAN, I. R. A status report on plantonic cianobactéria (blue-green algae) and their toxins. EPA/600/R-92/079, jun. 1992. 
CARMICHAEL,W. W. Cyanobacteria secondary metabolitos - The cyanotoxins. Journal of Applied Bacteriology, n. 72, p. 445-459, 1992.

CASS, Q. B.; DEGANI, L. G. Desenvolvimentos de métodos pó HPLC : fundamentos, estratégias, e validação. São Carlos: EDUFSCAR, p. 11-17 (Série Apontamentos), 2001.

CAVALLI, V.; CIDRAL, J. R.; NILSON, R. Contagem de cianobactérias do gênero Microcystis e determinação de microcistinas pelo método de imunoensaio competitivo no controle de tratamento de água para abastecimento. In: ASSEMBLÉIA NACIONAL DA ASSEMAE, 35; EXPOSICÃO DE EXPERIÊNCIAS MUNICIPAIS EM SANEAMENTO, 9. 2005. Belo Horizonte: Assemae, 2005. 10 p. Disponível em: <http://www.semasa.sp.gov.br/admin/biblioteca/docs/pdf/35Assemae119.pdf>. Acesso em: 03 fev. 2009.

CHORUS, I.; BARTRAM, J. Toxic cyanobacteria in water: guide to their public health consequences. Monitoring and management. London: E \& E.N. Spon., 1999. $416 \mathrm{p}$.

CHU, F. S.; HUANG, X.; WEI, R. D. Enzyme-linked immunosorbent assay for microcystins in blue green algae blooms. Journal of Association of Official Analytical Chemists, v. 73, p. 451-456, 1990.

COELHO, S. R. de C. Situação atual e perspectiva da industria de rações para organismos aquáticos. In: SIMPÓSIO SOBRE MANEJO E NUTRIÇÃO DE PEIXES, 1997, Piracicaba/SP. Anais... p. 102-115. Campinas: Colégio Brasileiro de Nutrição Animal, 1997.

CETESB - COMPANHIA DE TECNOLOGIA DE SANEAMENTO AMBIENTAL Procedimentos para utilização de testes de toxicidade no controle de efluentes líquidos. São Paulo: CETESB, 1990. 17p. (Série manuais, n.6).

DEBERT, G. L. B.; CANTUSIO NETO, R.; AGUJARO, L. F. Florações de cianobactérias e sua inserção na legislação brasileira. 2004. Disponível em: <http://dtr2001.saude.gov.br/editora/produtos/impressos/cartaz/04_0510_C.pdf>. Acesso em: 04 fev. 2009.

CONAMA - CONSELHO NACIONAL DO MEIO AMBIENTE -. Resolução n. 357, de 17 de março de 2005. Dispõe sobre a classificação dos corpos de água e diretrizes ambientais para seu enquadramento, bem como estabelece as condições e padrões 
de lançamento de efluentes, e dá outras providências. Diário Oficial [da República Federativa do Brasil], Brasília, n. 53, p. 58-63, 18 março 2005. Seção 1

ELER, M. N.; CECCARELLI, P. S.; BUFON, A. G. M.; ESPÍNDOLA, E. L. G. Mortandade de peixes em viveiros de piscicultura. Boletim Técnico do CEPTA, $v$. 14 , p. 35-45, 2001.

ELER, M. N. Efeito da densidade de estocagem de peixes e do fluxo de água na qualidade da água e na sucessão do plâncton em viveiros de piscicultura. 2000. 258f. Tese (Doutorado) - Escola de Engenharia de São Carlos, Departamento de Hidráulica e Saneamento, Universidade de São Paulo, São Carlos, SP.

ELER, M. N. Influência do pacu (Piaractus mesopotamicus, HOLMBERG, 1887) e do fluxo contínuo de água nas características limnológicas e viveiros de piscicultura. 1996. 158f. Dissertação (Mestrado) - Escola de Engenharia de São Carlos, Centro de Recursos Hídricos e Ecologia Aplicada, Universidade de São Paulo, São Carlos,SP.

ELER, M. N.; CAMPAGNA, A. F.; MINILLO, A.; RIBEIRO, M. A. R.; ESPÍNDOLA, E. L. G. Water quality, toxicity and gill lesions caused by intraperitoneally administered water-bloom crude extract in Brycon cephalus (Günther, 1896; Characidae) from fee-fishing ponds in São Paulo state, Brazil. Acta Limnologica Brasiliensia, v. 21, n. 1, p. 89-100, 2009.

ELER, M. N.; ESPÍNDOLA, E. L. G.; ESPÍNDOLA, E. A.; BRIGANTE, J.; NOGUEIRA, M. M.; NOGUEIRA, A. M.; MILANI, T. J. Avaliação da qualidade da água e sedimento dos pesques-pague: Análises físicas, químicas, biológicas e bioensaios de toxicidade. In: ESPÍNDOLA, E.L.G.; ELER, M.N. Avaliação dos impactos de pesque-pague: uma análise da atividade na bacia hidrográfica do rio Mogi-guaçu. São Carlos: RiMa, p. 100-144, 2006.

ELER, M. N.; MINILLO, A.; RIBEIRO, M. A. R.; DE BEM, T. H. C.; SANTOS, N. P.dos; BLAZQUEZ, F. J. H.; MILANI, T. J.; ESPÍNDOLA, E. L. G.; NOGUEIRA, A. $M$. Cianobactérias, toxinas e bioensaios ecotoxicológicos nos pesque-pague da bacia hidrográfica do Mogi-Guaçu. In: ESPÍNDOLA, E.L.G.; ELER, M.N. Avaliação dos impactos de pesque-pague: uma análise da atividade na bacia hidrográfica do rio Mogi-guaçu. São Carlos: RiMa, 2006. p. 145-162.

FALCONER, I. R. Cyanobacterial toxins of drinking water supplies:

Cylindrospermopsins and Microcystins. Boca Raton: CRC Press, 2004. 279 p. 
FISCHER, W. J.; DIETRICH, D. R. Pathological and biochemical characterization of Microcystin-induced hepatopancreas and kidney damage in carp (Cyprinus carpio). Toxicology and Applied Pharmacology. 164, 73-81, 2000.

FUNASA - FUNDAÇÃO NACIONAL DE SAÚDE. MINISTÉRIO DA SAÚDE (MS). Portaria no 1.469 , de 29 de dezembro de 2000. Estabelece os procedimentos e responsabilidades relativos ao controle e vigilância da qualidade da água para consumo humano e seu padrão de potabilidade, e dá outras providências. Republicada no Diário Oficial [da República Federativa do Brasil], Brasília, n. 38, p. 39, 22 fev. 2001.

GLIBERT, P. M.; LANDSBERG, J. H.; EVANS, J. J.; AL-SARAWI, M. A.; FARAJ, M.; AL-JARALLAH, M. A.; HAYWOOD, A.; IBRAHEM, S.; KLESIUS, P.; POWELL, C.; SHOEMAKER, C. A. A fish kill of massive proportion in Kuwait Bay, Arabian Gulf, 2001: the roles of bacterial disease, harmful algae, and eutrophication. Harmful Algae, v.1, n.2, p. 215-231, 2002.

GOLTERMAN, H. L.; CLYMO, R. S.; OHNSTAND, M. A. Methods for physical and chemical analysis of fresh water. Oxford: Blackwell Scientific Publications, 1978, 213 p. (IPB Handbook, n.8).

GUMBO, R. J.; ROSS, G.; CLOETE, E. T. Biological control of Microcystis dominated harmful algal blooms. African Journal of Biotechnology, v. 7, n. 25, p. 4765-4773, 2008.

HAMILTON, M. A.; RUSSO, R. C.; THURSTON, R. V. Trimmed Spearman-Karber method for stimating median lethal concentrations in toxicity bioassays.

Environmental Science and Technology, v. 11, p. 714-719, 1977.

HINO, K.; TUNDISI, J. G. Atlas de algas da Represa do Broa. São Carlos: Departamento de Ciências Biológicas da Universidade Federal de São Carlos, 1977. 143 p. (Série Atlas, v.2)

IBAMA - INSTITUTO BRASILEIRO DO MEIO AMBIENTE E DOS RECURSOS NATURAIS RENOVÁVEIS. Diretoria de Fauna e Recursos Pesqueiros. Coordenação Geral de Gestão de Recursos Pesqueiros. Estatística da Pesca 2005: Brasil grandes regiões e unidades da Federação. Brasília: IBAMA, 2007. 147 p. 
KAMOGAE, M.; TSUTSUMI, T.; NAGATA, S.; AYMOTO, N. M.; UENO, Y.; HIROOKA, E. Y. Monitoring of microcystins in fresh water for human consumption in the Itaipu Dam, Paraná-Brazil. Braz. J. Food Technol., v. 5, p. 109-116, 2002.

KANKAANPÄÄ, H.; VUORINEN, P. J.; SIPIÄ, V.; KEINÄNEN, M. Acute effects and bioaccumulation of nodularin in sea trout (Salmo trutta $\mathrm{m}$. trutta L.) exposed orally to Nodularia spumigena under laboratory conditions. Aquatic Toxicology, v. 61, p. 155-168, 2002.

KITAMURA, P. C.; LOPES, R. B.; CASTRO JR, F. G. de.; QUEIROZ, J. F. Avaliação ambiental e econômica dos lagos de pesca esportiva na bacia do rio Piracicaba. Boletim de Indústria Animal de Nova Odessa, v. 56, p. 1-13, 1999.

KOROLEF, F. Determination of nutrients. In: Grasshoff, K (ed). Methods of Seawater Analysis Verlag Chemie Weinhein, p. 117-171, 1976.

KOTAK, G. B.; SEMALULU, S.; FRITZ, D. L.; PREPAS, E. E.; HRUDEY, S. E.; COPPOCK, R. W. Hepatical and renal patology of intraperitoneally administered microcystin-LR in rainbow trout (Onchorhynchus myskiss). Toxicon, v. 34, n. 5, p. 517-525, 1996.

LACHI, G. B., SIPAÚBA-TAVARES, L. H. Qualidade da água e composição fitoplanctônica de um viveiro de piscicultura utilizado para fins de pesca esportiva e irrigação. B. Inst. Pesca, São Paulo, v. 34 n. 1, p. 29 - 38, 2008.

LANDSBERG, J. H. The Effects of Harmful Algal Blooms on Aquatic Organisms. Reviews in Fisheries Science, v. 10 n. 2, p. 113-390, 2002.

LINDHOLM, T.; ÖHMAN, P.; KURKI-HELASMO, K.; KINCAID, B.; MERILUOTO, J. Toxic algae and fish mortality in a brackish-water lake in Åland, SW Finland.

Hydrobiologia, v. 397, p. 109-120, 1999.

LÜTZHØFT, H. C. H.; HALLING-SØRENSEN, B. H.; JØRGENSEN, S. E. Algal toxicity of antibacterial agents applied in Danish fish farming. Archives of

Environmental Contamination and Toxicology, v. 36, p. 1-6, 1999.

MAGALHÃES, V. F.; MARINHO, M. M.; DOMINGOS, P.; OLIVEIRA, A. C.; COSTA, S. O.; AZEVEDO, L. O.; AZEVEDO, S. M. F. O. Microcystins (Cyanobacteria 
Hepatotoxins) bioaccumulation in fish and crustaceans from Sepetiba Bay (BrazilRJ). Toxicon, v. 42, p. 289-295, 2003.

MAHMOOD, N. A.; CARMICHAEL, W. W. Paralytic shellfish poison product by the freshwater Cyanobacterium Aphanizomenon flos-aquae NH-5. Toxicon, v. 24, p. 175-186, 1986.

MACKERETH, F.J. H.; HERON, J.; TALLING, J. F. Water analysis: some revised methods for limnologists. England: Scientific Publication. 1978. 121 p.

MELETTI, P. C. Avaliação da degradação ambiental por meio de testes de toxicidade com sedimentos e de análises histopatológicas em peixes. 2003. 209f. Tese (Doutorado) - Escola de Engenharia de São Carlos, Universidade de São Paulo, São Carlos.

MERILUOTO, J.; SPOOF, L. Solid phase extraction of microcystins in water simples. In: MERILUOTO, J.; CODD, G.A. TOXIC European Project "cyanobacterial monitoring and cyanotoxins analysis". Turku: Abo Akademi University, 2005. p.73.

MINILLO, A. Análise da distribuição, densidade e toxicidade de florações de cianobactérias e suas toxinas nos reservatórios do médio e baixo rio Tietê (SP) em relação com as características limnológicas do sistema. 2005. 400f. Tese (Doutorado) - Escola de Engenharia de São Carlos, Ciências da Engenharia Ambiental, Universidade de São Paulo, São Carlos-SP.

MOLINA, R.; MORENO, I.; PICHARDO, S.; JOS, A.; MOYANO, R.; MONTERDE, J. G.; CAMEÁN, A. Acid and alkaline phosphatase activities and pathological changes induced in Tilapia fish (Oreochromis sp.) exposed subchronically to microcystins from toxic cyanobacterial blooms under laboratory conditions. Toxicon, v. 46, n. 7 , p. 725-735, 2005.

$\mathrm{NUSCH}, \mathrm{E}$. A. Comparison of different methods for Clorophyll and phaeopigments determination. Arch. fur Hidrobiol., v. 14, p. 14-36, 1980.

OVERBECK, J. Conceitos de ecossistema. In: JORGENSEN, S. E.;

VOLLENWEIDER, R. A. (Eds.) Diretrizes para o gerenciamento de lagos. V. 1 
Princípios para o gerenciamento de lagos. Tradução de Vannucci, D.; Editor da série em português Tundisi, J. G. São Carlos: ILEC; IIE; UNEP, p. 9-25, 2000.

PAERL, H. W.; TUCKER, C. S. Ecology of blue-green algae in aquaculture ponds. Journal of the World Aquaculture Society, v. 26, n. 2, p. 109-131, 1995.

PHILLIPS, M. J.; ROBERTS, R. J.; STEWART, J. A.; CODD, G. The toxicity of the cyanobacterium Microcystis aeuginosa to rainbow trout Salmo gairdneri Richardson. Journal of Fish Diseases, v. 8, p. 339-344, 1995.

POLEKSIĆ, V.; MITROVIĆ-TUTUNDŽIĆ, V. Fish gills as a monitor of sublethal and chronic effects of pollution. In: MÜLLER, R.; LLOYD, R. (Eds.) Sublethal and chronic effects of pollutants on freshwater fish. Cambridge : Fishing New Books, p. 339-352, 1994.

RABERGH, C. M. I.; BYLUND, G.; ERIKSON, J. E. Histopathological effects of microcystin-LR, a cyclic peptidetoxin from the cyanobacterium (blue-green algae) Microcystis aeruginosa, on common carp (Cyprinus carpio L.). Aquatic Toxicology, v. 20, p. 131-146, 1991.

REIS, A. B.; SANT'ANA, D. de M. G.; AZEVEDO, J. F. de; MERLINI, L. S.; ARAÚJO, E. J. de A. Alterações do epitélio branquial e das lamelas de tilápias (Oreochromis niloticus) causadas por mudanças do ambiente aquático em tanques de cultivo intensivo. Pesq. Vet. Bras., v. 29, n. 4, p. 303-311, 2009.

RELATÓRIO ZERO. Comitê de bacia do Rio Mogi-Guaçu. Pirassununga: CETESB. 1999. 200 p.

RIGOLIN-SÁ, O. Avaliação da toxicidade de herbicida Roundup (glifosato) e do acaricida Omite (propargito) nas fases iniciais da ontogenia do bagre, Rhamdia hilarii (Valenciennes, 1840) (Pimelodidae, Siluriforme). 1998. 309f. Tese (Doutorado) - Universidade Federal de São Carlos, São Carlos.

RODGER, H. D.; TURNBULL, T.; EDWARDS, C.; CODD, G. A. Cyanobacterial (blue-green algae) associated pathology in browm trout (Salmo trutta L.) in Loch Leven, Scotland. Journal of Fish Diseases, v. 17, p. 177-181, 1994. 
SANT'ANNA, C. L.; AZEVEDO, M. T. de P.; SORMUS, L. Fitoplâncton do Lago das garças, Parque Estadual das Fontes do Ipiranga, São Paulo, SP, Brasil: Estudo taxonômico e aspectos ecológicos. Hoehnea, v. 16, p. 89-131, 1989.

SANTOS, A. P. M. E. dos; BRACARENSE, A. P. F. R. L. Hepatotoxicity with microcystin. Ciências Agrárias, v. 29, n. 2, p. 417-430, 2008.

SIPAÚBA-TAVARES, L. H., MORENO, S. Q. Variação dos parâmetros limnológicos em um viveiro de piscicultura nos períodos de seca e de chuva. Rev. UNIMAR, v. 16, n. 3, p. 229-242, 1994.

SIPAÚBA-TAVARES, L.H. Limnologia aplicada à aqüicultura. Jaboticabal: FUNEP, 1995, $70 \mathrm{p}$.

SIPIÄ, V.; KANKAANPÄÄ, H.; LAHTI, K.; CARMICHAEL, W. W.; MERILUOTO, J. Detection of Nodularin in flounders and cod from the Baltic Sea. Environmental Toxicology, v. 16, p. 121-126, 2001.

SOARES, R. M.; MAGALHÃES, V. F.; AZEVEDO, S. M. F. O. Accumulation and depuration of microcystins (Cyanobacteria hepatotoxins) in Tilapia rendalli (Cichlidae) under laboratory conditions. Aquatic Toxicology, v. 70, p. 1-10, 2004.

SOARES, R. M. Toxiologia de cianotoxinas: microcistinas as estrelas do tema. Oecologia brasiliensis, v. 13, n. 2, p. 259-271, 2009.

SOUSA, R. M. Trabalho de Limnologia biota. 2009. Disponível em: http://www.webartigos.com/articles/20647/1/cianobactérias-e-Suas-Toxinas/pagina1.html. Acesso em: 07 abr. 2010.

TAKASHIMA, F.; HIBIYA, T. An atlas of fish Histology: normal and pathological features. Tokyo: Kodansha, 1995. 195 p.

TSUKAMOTO, R. Y.; TAKAHASHI, N. S. Cianobactérias + Civilização = Problemas para a Saúde, a Aqüicultura e a Natureza. Panorama da Aqüicultura, v. 17, n. 103, p. 24-33, 2007.

TUCKER, C. S.; PLÖEG, M. van der Seasonal changes in water quality in commercial channel catfish culture ponds in Mississippi. Journal of the World Aquaculture Society, v. 24, p. 473-481, 1993. 
VALDERRAMA, J. C. The silmutaneous analysis of TN e TP in natural waters. Mar. Chem., v. 10, p. 109-112, 1981.

VASCONCELOS, V. M. Cyanobacterial toxins in Portugal: effects on a aquatic animals and risk for human health. Brazilian Journal of Medical and Biological Research, v. 32, p. 249-254, 1999.

XIE, L.; XIE, P.; OZAWAB, K.; HONMA, T.; YOKOYAMA, A.; PARK, H. Dynamics of Microscystins-LR and RR in the phytoplanktivorous silver carp in a sub-chronic toxicity experiment. Environmental Pollution, v. 127, p. 431-439, 2004.

WETZEL, R. G.; LIKENS, G. E. Limnological analyses. New York: W.B. Saunders Company, 2 ed., 1991. 391p.

ZIMBA, P.; GRIMM, C. C.; DIONIGI, C. P.; WEIRICH, D. C. Phytoplancton community structure and off-flavor levels in Louisiana catfish ponds. Journal of the World Aquaculture Society, v. 32, n. 1, p. 96-104, 2001. 
ANEXOS 


\section{ANEXO 1}

Etapa 1

\section{UNIVERSIDADE DE SÃO PAULO \\ DEPARTAMENTO - ZAZIFZEA/USP \\ CENTRO NACIONAL DE PESQUISA E CONSERVAÇÃO DE PEIXES \\ CONTINENTAIS - CEPTA}

Formulário 1- Pesque e pague :

Data:

Localização: Município:

\section{IDENTIFICAÇÃO}

administrativa:

Área total da propriedade:

Área hídrica para pesca:( ) Represas $\mathrm{N}^{0}$

() Viveiros $\mathrm{N}^{0}$ área

( ) Somente Pesque-pague Outros

Área hídrica total para o peque-pague:

Rio ( ) Poço ( ) Açude ( )outros:

Sistema de captação da água:

( ) Gravidade ( ) Bombeamento direto (capac. da bomba)

( ) Bombeamento com filtro ( ) Gravidade/Bombeamento

Disponibilidade de infra-estrutura elétrica: ( ) Sim Não ( ) Gerador ( )

Outros:

Disponibilidade de água encanada: ( ) Sim ( ) Não

Disponibilidade de infra-estrutura de comunicação:

( ) Telefone ( ) Rádio Fax ( ) Telex ( ) Internet ( ) S/comunicação

( ) outros:

Condições de acesso à propriedade:
( ) Asfalto
() Outros
( ) Estrada de terra
( ) Asfalto/estrada de terra ( ) Balsa

Qual a cidade mais próxima?

Distância da propriedade à cidade mais próxima:

\section{CARACTERIZAÇÃO DA PROPRIEDADE}

Tipo de sistema empregado:

( ) Pesque e pague ( ) Pesque e solte ( )outros

Dias/horário de funcionamento:

Serviços que oferece, além da pesca:

( ) Hotelaria ( ) Camping ( ) Restaurante (simples / completo) ( ) Lanchonete

( ) Trilhas ( ) Cavalos () Recreacionistas ( ) Serviço de beira de lago ( )

Play ground ( ) Instrutores ( ) Loja de pesca ( ) Limpeza do peixe ( )

outros:

Sistema de controle: ( ) Comanda ( ) Crachá )outros:

Capacidade de atendimento: $\mathrm{N}^{0}$ de pessoas: $\mathrm{N}^{0}$ de Carros

\section{PREÇOS MÉDIOS PRATICADOS}

Entrada: 
Homem: Mulher: Criança: Kg de peixe :

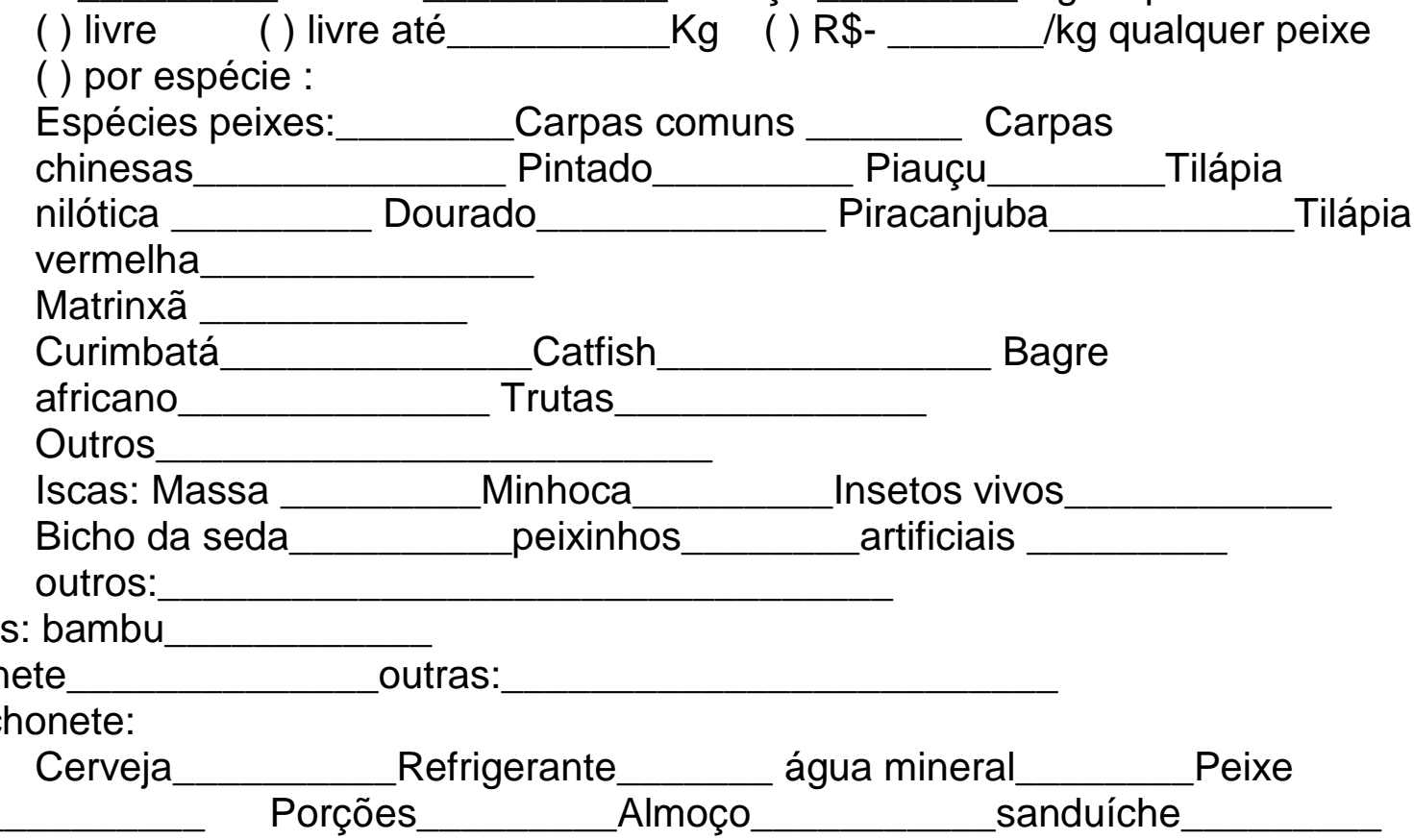

Varas: bambu

molinete Carpas comuns Piauçu sanduíche
Cerveja
frito
Porções Almoço

Freqüência de abastecimento: Na temporada

() Produção própria ( ) Fornecedor específico
() Qualquer fornecedor que tenha preço bom

Temporada

Irregular

Quantidade média adquirida/mês: Na temporada:

Fora da

temporada Irregular

Preço médio do kg/peso médio do peixe:

Peixes redondos

comuns:

chinesas I

Tilápia

nilótica

\section{Tilápia}

vermelha

Matrinxã

Carpas

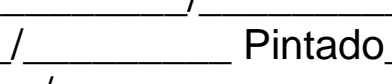

Bagre africano Catfish Curimbatá

Dourado

Piracanjuba

Curimbatá

é feito o transporte dos peixes:

Como é feito o transporte dos peixe
( ) Empresa especializada

( ) Transportador autônomo

( ) Transporte próprio

Iscas ( ) Produção própria

( ) Transporte do piscicultor

( ) Qualquer fornecedor que tenha preço bom

Preço médio das iscas: Massa

Bicho da seda

Minhoca

Insetos vivos

Peixinhos outros 
Lanchonete: ( ) Exploração própria ( ) Terceirizada
Loja de pesca: ( ) Não tem
( ) Própria
( ) Terceirizada
( ) Completa
( ) Simples
Outros serviços: ( ) Próprios
( ) Terceirizados

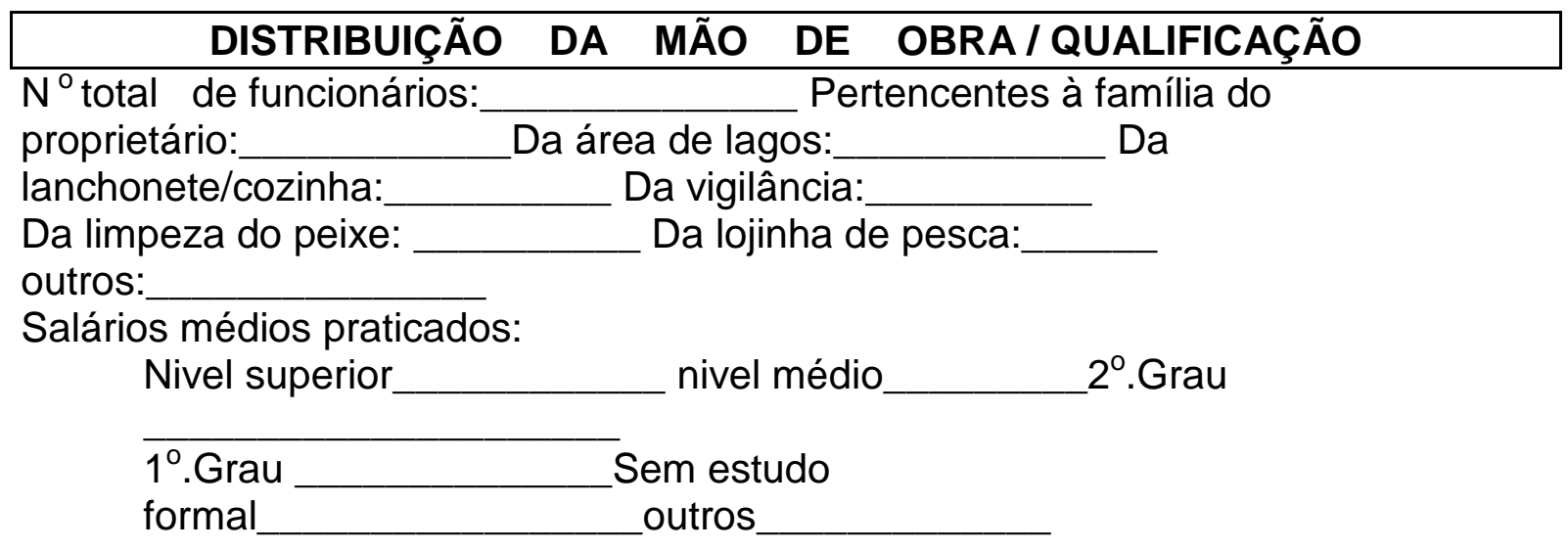

Treinamento específico: ( ) sim ( ) não

Em caso positivo, quem/onde/duração

( ) Proprietário ( ) Gerente ( ) Técnico ( ) Funcionário de campo

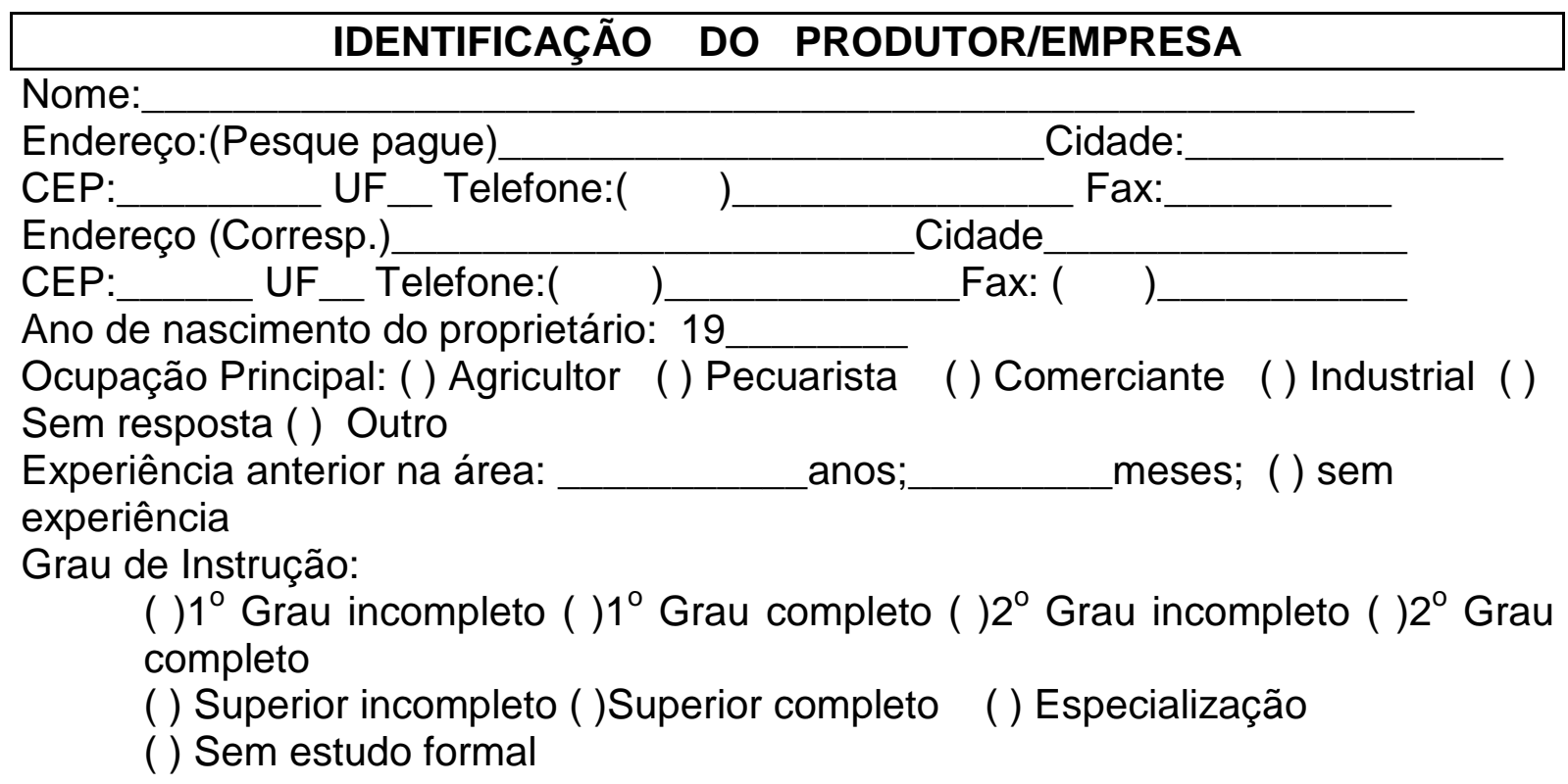

\section{INFORMAÇÕES SOBRE O PROJETO}

Em que ano iniciou o empreendimento?

O que o levou a montar o pesque e pague?
( ) era fazendeiro e resolveu diversificar a produção;
( ) tinha uma propriedade sem gerar renda e resolveu investir numa atividade lucrativa;
( ) tinha uma propriedade e decidiu investir numa atividade que desse prazer;
( ) influenciado pelo bom desempenho de outros pesqueiros
() outros

Reside na propriedade? ( ) sim ( ) não

Em caso negativo qual é a freqüência que visita a propriedade? 

() Uma vez por dia
( ) Algumas vezes na semana
() Uma vez por mês
() Raramente

( ) Nunca visitou

Quem elaborou o projeto de implantação?
( ) Empresa especializada
( ) Técnico especializado
( ) Órgão de fomento
( ) O próprio produtor/empresário ()
( ) Sem resposta
Outros

Quem fez a legalização do projeto?
( ) Empresa especializada
( ) Técnico especializado
( ) Órgão de fomento
( ) Outros
( ) O próprio produtor/empresário ( ) Não tem legalização

Quanto tempo o projeto levou para ser implantado?

anos

( ) Menos de um ano ( ) Entre 1 e 2 anos () Entre 2 e 3 anos () Mais de 3

Como foi iniciado o empreendimento?

( ) Sozinho ( ) Com a família ( ) Com sócios ( ) outros:

Como vem sendo conduzido o investimento?

( ) Sozinho () Com a família ( ) Com sócios ( ) outros:

Tem assessoria técnica ou comercial externa ? () sim () não

Como faz a divulgação do pesque-pague?
( ) Verbal
( ) Folhetos
() Faixas
( )Rádio
( ) Jornais

Revistas ( ) Televisão ( ) Internet ( ) outros

Em quanto montou o investimento?

Valor total:

Construção dos lagos:

Construção da lanchonete/restaurante:

Povoamento:

Equipagem:

Qual a fonte de recursos? ( ) Recursos próprios ( ) Financiamento

Em caso de financiamento, indicar a fonte/valor US\$

Qual a finalidade do financiamento?

( ) Implantação ( ) Manutenção ( ) Implantação/manutenção

( ) Ampliação

( ) Capital de giro para comercialização

Composição mensal de custos do pesqueiro:

( ) Outra

Salários: Energia elétrica

Peixes Ração

Iscas

Insumos para lanchonete

outros

Densidade de povoamento

\section{INFORMAÇÕES SOBRE O MANEJO}

Manejo alimentar: Arraçoamento ( ) não ( ) sim (freq.)

Tipo de ração: ( ) Peletizada ( ) Extrusada ( ) Farelada ( ) outra

Manejo da água: ( )Aeração suplementar ( $n^{\circ}$ aeradores): bombeamento ( ) Aer. por

( ) Seca periodicamente (freq.) ( ) Não seca 
Controle de parâmetros ambientais/freqüência: （ ) Não （ ) Sim

( ) $\mathrm{pH}$

( )Oxigênio

( ) Amônia

( ) Temperatura

( ) transparência

( ) fósforo total

( ) nitrogênio total ( ) outros:

Profilaxia: ( ) Sim ( ) Não (caso positivo, ver anexo listar em anexo os medicamentos)

Controle de enfermidades: ( ) Sim *(anexo) ( )Não (listar o produto em anexo)

Tratamento dos tanques: ( ) não realiza ( ) Limpeza de fundo ( ) Expurgo com cal

( ) outros

Tratamento de efluentes dos viveiros antes do lançamento no rio ( ) sim ( ) não

Afirmativa negativa porque ( ) falta de informação ( ) não há necessidade ( ) é muito importante, mas fica muito caro.

O Senhor tem conhecimento das leis de preservação ambiental? ( ) sim ( )não

O senhor está ciente da lei de recursos hídricos, que terá uma taxa de cobrança

pelo uso da água? ( ) sim ( ) não

Se não tinha conhecimento dê sua opinão:

\section{INFORMAÇÕES SOBRE OS FREQÜENTADORES DO PESQUEIRO}

$\mathrm{N}^{0}$. Médio de pescadores fim de semana/feriados

Temporada I___ Fora da temporada

$\mathrm{N}^{0}$. Médio de pescadores durante a semana

Temporada

Fora da temporada

Distribuição média por idade/sexo:

adultos (20-50): homens $\%$ mulheres

crianças (até 12 anos )

$\%$ jovens (13-20 anos) $\%$

$\%$ terceira idade (acima de 50 anos) $\%$

famílias

Origem mais comum do freqüentador: ( ) Da região ( ) De São Paulo ( ) De outras regiões

Perfil médio dos freqüentadores do pesqueiro:

( ) Classe alta e vem sozinho; ( ) Classe alta e vem com amigos ( )

Classe alta e vem com a família; ( ) Classe média e vem sozinho; ( )

Classe média e vem com amigos;

( ) Classe média e vem com a família; ( )Assalariado e vem sozinho; ( )

Assalariado e vem com amigos; ( ) Assalariado e vem com a família; ( )

Aposentados; ( ) outros

Tempo médio de permanência:

Temporada

Fora temporada

Fim de semana/feriados Durante a

semana

Valor médio dispendido no pesqueiro/pescador:

Temporada

Fora temporada

Fim de semana/feriados Durante a

semana

Quantidade média de peixes pescada/fim de semana/mês (Kg)

temporada

Temporada

1
Fora da 


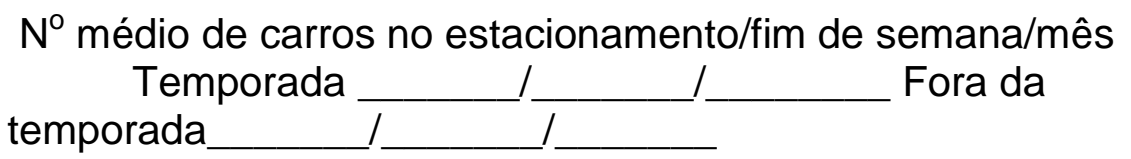

SITUAÇÃO LEGAL

( ) Não sabia que era preciso legalizar o pesqueiro

( ) Não sabia onde teria que legalizar

( ) Sabia mas era muito complicado, resolveu não fazer

( ) Deu entrada mas ainda não conseguiu as outorgas

( ) DEPRN ( )DAEE ( ) IBAMA ( ) DUSM （）CETESB

( ) PREFEITURA

Está esperando a

) Tem o pesque-pague legalizado (tempo)

\section{PROBLEMAS MAIS FREQUENTES}

( ) Fornecimento irregular de peixes

( ) Falta de mão de obra

( ) Baixa qualidade dos peixes

( ) Mortalidades no transporte

( ) Mortalidade no pesque-pague

( ) Distancia das pisciculturas

( ) Água de má qualidade

\section{PRINCIPAIS DIFICULDADES}

( ) Falta de linhas de crédito

( ) Burocracia para legalização

( ) Falta de assessoria técnica

( ) Idoneidade de fornecedores

( ) Preços dos peixes

( ) Preço da ração

( ) Qualidade da ração

( ) Ocorrência de doenças/quais as mais freqüentes

( ) Forte concorrência de outros pesque-pague

( ) outras (quais)

Como o Sr. avalia o seu negócio?

( )Não dá lucro, só cobre as despesas（ ) Dá pouco lucro

( ) Dá prejuízo

( ) Dá um bom lucro; ( ) outros

Pretende continuar na atividade ( ) sim ( ) não

Em caso negativo, por que?

\section{SUGESTÕES}

O que o Sr. sugere para melhorar a atividade em relação à preservação do ambiente?

Que conselho o Sr. daria para quem quer montar um pesque-pague? 


\section{FORNECEDORES HABITUAIS/Peixes - Alevinos}

Pesqueiro/Piscicultura:

Cidade:

RA:

\begin{tabular}{|l|l|l|l|l|l|}
\hline Nome & Telefone & Cidade & Espécies & Preço & Avaliação \\
\hline & & & & & \\
\hline & & & & & \\
\hline & & & & & \\
\hline & & & & & \\
\hline & & & & & \\
\hline
\end{tabular}

\section{FORNECEDORES HABITUAIS/Iscas}

Pesqueiro/Piscicultura:

Cidade:

RA:

\begin{tabular}{|l|l|l|l|l|l|}
\hline Nome & Telefone & Cidade & Espécies & Preço & Avaliação \\
\hline & & & & & \\
\hline & & & & & \\
\hline & & & & & \\
\hline & & & & & \\
\hline & & & & & \\
\hline
\end{tabular}

TRANSPORTADORES HABITUAIS

Pesqueiro/Piscicultura:

Cidade:

RA:

\begin{tabular}{|l|l|l|l|l|l|}
\hline Nome & Telefone & Cidade & Espécies & Preço & Avaliação \\
\hline & & & & & \\
\hline & & & & & \\
\hline & & & & & \\
\hline & & & & & \\
\hline & & & & & \\
\hline
\end{tabular}

\section{PROFILAXIA E TRATAMENTO DE DOENÇAS}

Pesqueiro/Piscicultura:

Cidade:

RA:

Produto/Fabricante

Objetivo

Dosagem

Resultado 
ANEXO 2

\section{UNIVERSIDADE DE SÃO PAULO \\ DEPARTAMENTO - ZAZIFZEA/USP \\ CENTRO NACIONAL DE PESQUISA E CONSERVAÇÃO DE PEIXES \\ CONTINENTAIS - CEPTA/ICMBIO}

Formulário 2- Cliente

Data:

Nome do Pesque-pague

Percepção Ambiental, Social e Econômica

Nome do Cliente:

Sexo: Feminino ( ) Masculino ( )

Faixa etária

( ) menos de 10 anos ( ) entre 10 e 20 anos ( ) 20 a 30 anos

( ) de 30 a 40 anos ( ) 40 a 50 anos ( ) 50 a 60 anos

( ) acima de 60 anos

Ocupação Principal

( ) Agricultor ( ) Pecuarista ( ) Profissional liberal ( ) Industrial Estudante

( ) Comerciante ( ) Funcionário público ( ) Aposentado ( ) Desempregado

( ) Outros

Grau de Instrução

( ) $1^{\circ}$ Grau incompleto ( $) 1^{\circ}$ grau completo ( $) 2^{\circ}$ Grau incompleto

( ) $2^{\circ}$ grau completo ( ) Superior incompleto ( )Superior completo

( )Sem estudo formal.

1 - Qual a sua freqüência a um pesque-pague

( ) diária ( ) semanal ( ) quinzenal ( ) somente aos feriados

( ) mensal ( ) anual ( ) todos os fins de semana ( ) nas minhas férias

( ) eventual (de vez em quando) ( ) durante a semana

Com quem você vem pescar?

( ) Sozinho ( ) com os amigos ( ) com a família

Quanto tempo você costuma ficar no pesque-pague?

2 - Porque você vem a um pesque-pague

( ) porque gosto de pescar;

( ) porque meus amigos me convidaram;

( ) porque aqui se pesca com maior facilidade ;

( ) porque posso trazer minha família e me divertir com eles pescando;

( ) porque esqueço dos meus problemas quando estou pescando;

( ) porque posso levar comida para casa e ao mesmo tempo me divertir;

( ) porque o pesque-pague tem um bom atendimento, bons peixes e a paisagem é bonita; 
( ) porque pescar aqui é melhor do que no rio, afinal aqui tem mais conforto e a certeza de fisgar um bom peixe;

( ) porque gosto de peixe esportivo e bom de briga, aqui no pesque-pague sempre encontro o peixe esportivo.

3 - Quais os peixes de sua preferência

( ) Peixes redondos ( )Carpas comuns ( ) Carpas chinesas ( ) Pintado

( ) Piauçu ( ) Tilápia nilótica ( ) Dourado ( )Piracanjuba ( )Traíra

( ) Tilápia vermelha ( ) Matrinxã （）Curimbatá （）Catfish ( ) Bagre africano Outros

Quantidade de peixe pescada/visita

Quanto você costuma gastar no pesque-pague/visita

4 - O que o deixa satisfeito em um pesque-pague? Marque MI para muito importante, I para importante e PC para pouco importante. Dê uma nota de 0 a 10 para este pesque-pague.

( )Facilidade de acesso ( ) Ter bastante peixes

Banheiros limpos e com boa apresentação

( ) Variedade de iscas peixes

( )Restaurante

) Outras atividades além da pesca

( ) Parque de diversão para a criançada

( ) Lanchonete bem equipada e com boas condições de higiene

( )Atendimento cordial e prestativo ao freguês ( ) Simpatia no atendimento

( ) Variedade de peixes ( ) Equipamentos para a pesca $($ ) Estacionamento

( ) Serviço de beira do lago

( ) Limpeza nas margens do lago (retirada freqüente de lixo)

( )Disposição ao longo do lago de latas de lixo

( )Árvores na beira do lago, proporcionando sombra

( )Beleza da paisagem do pesque-pague

( )Boa procedência de peixes no pesque-pague (com garantia de qualidade)

( )Preços atraentes e competitivos do quilo de peixes

5 - Você relaciona a cor e o cheiro da água do lago com a boa qualidade do peixe ( ) $\operatorname{sim}$ ( ) não

Qual a cor da água deste lago no qual você está pescando ( ) verde ( ) verde-azulada ( ) marrom barrenta ( ) suja ( ) limpa E o cheiro? ( ) cheiro de mofo ( ) cheiro de peixe ( ) cheiro de formicida ( ) cheiro de água ( ) tem cheiro de esgoto.

6 - Se você soubesse que foi colocado remédio na água para tratar o peixe na semana passada você estaria pescando hoje?

( ) $\operatorname{sim}$ ( ) não ( ) não pescaria porque a carne do peixe pode ser prejudicial a minha saúde

( ) acho que não há problema em pescar eu não vou comer o peixe. 